\title{
SIMPLE STEPS FOR SUCCESSFUL AGEING
}

A project report on: Innovation and commercialisation opportunities related to enabling safe and independent access to high places at home for older consumers.

BY

YU HAN GELINE LIM

\begin{abstract}
A thesis
submitted to the Victoria University of Wellington In fulfilment of the requirements for the degree of

Masters of Innovation and Commercialisation
\end{abstract}

Victoria University of Wellington

(2019) 


\begin{abstract}
This was a self-directed project inspired by personal concerns of ageing family members attempting to access high spaces at home, set in a wider context of a country, New Zealand, which has a rapidly ageing population. This is a research report on developing and commercialising innovations to enable safety and independence for ageing consumers, with a specific focus on safer access to high places at home.

In essence, the purpose of the project was to identify a product concept or concepts based on consumer needs and preferences, which could be realistically developed and commercialised, in the context of the New Zealand market. Due to time and resource constraints, the scope of the research was focused on identifying potential commercially viable opportunities and setting the foundation for future business development after the thesis, and did not aim to produce any physical product prototypes for testing. To embark on this project was important as it sought to recognise needs desired by seniors that may have been neglected and to advocate a more inclusive design in home tools.
\end{abstract}

The methodology employed was based on social constructionism, underpinned by grounded theory, and thus, was mainly qualitative in the form of semi-structured interviews. However, some minor quantitative components were included such as a final online survey consisting of closed questions. The research design was also influenced by the Business Canvas Model framework, in which theories on ageing and concepts from Consumer Behaviour and business strategy were integrated. 40 face-to-face, semistructured interviews were conducted with representatives from different stakeholder categories. A final online survey was administered with 21 responses from the initial 40 participants. All research data were then further analysed based on the Business Model Canvas framework to assess potential innovation and commercialisation opportunities in New Zealand.

The key findings were that an improved step ladder offered as a modular system where additional features could be added on was desired. The research highlighted the importance of developing a collaborative business model focusing on co-creating solutions for older consumers, with consumers. A step ladder concept titled Simple Steps and a new brand called HOMFI (Home Objects Made for Independence) was proposed. 
More research should be conducted with a larger group of participants to obtain a stronger quantifiable validations for a business case before actual resource investments. More developmental work has to be done, such as developing a functioning product prototype to be tested. A major implication for this project is the need to develop tools with the needs of older people in mind. This project could also set the foundation for potential future research in a global context, possibly enabling a similar study to be replicated in another country for the purpose of pursuing a global business strategy.

\section{Acknowledgements}

I would like to take this opportunity to express my sincerest gratitude to my primary supervisor, Judith Davey, who have been of incredible help. This thesis would have have been possible without her assistance. I would also like to thank Jenny Douche, the previous programme director of this Masters programme, and the new programme director, Matt Stevens. The invaluable advice and support of my mentor, Kevin Sheehy, is also greatly appreciated. Thanks are also due to all interview participants for their generous gift of time and perspectives. I would also like to thank Victoria University of Wellington and all staff who have contributed to this Masters programme. Additionally, I would like to thank my family and close friends for their encouragement and support. I would particularly like to dedicate this to my grandparents, and parents, who inspired me to embark on this journey. Finally, thank God I completed this. 
TABLE OF CONTENTS

\section{PART ONE: CONSUMER AND MARKET RESEARCH [CHAPTERS 1 - 4]}

Chapter

Page

\section{1: Introduction}

1.1 Overview of project

1.2 Inspirations and motivations for project

1.2.1 The "Successful Ageing" Movement

1.2.2 Specific objectives of research

1.2.3. Opportunities related to research

1.3 Proposed development strategy and business model 5

\begin{tabular}{l|l|l|}
1.4 & Review of assistive technology in the industry & 5
\end{tabular}

\begin{tabular}{l|l}
1.5 Literature review & 10
\end{tabular}

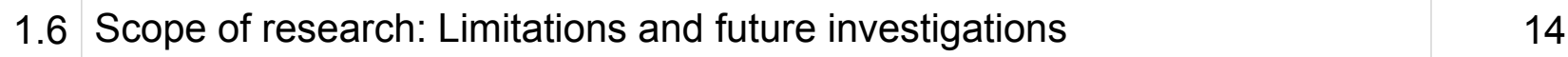

\begin{tabular}{l|l|l|}
1.7 Summary of research and outline of thesis & 15
\end{tabular}

\section{2: Methodology}

\begin{tabular}{l|l}
2.1 Overview & 18
\end{tabular}

\begin{tabular}{l|l|l}
\hline 2.2 & ASSUMPTIONS (Research paradigms and frameworks) & 19
\end{tabular}

\begin{tabular}{|l|l|}
2.3 & DECISION-MAKING FACTORS IN RESEARCH DESIGN
\end{tabular}

\begin{tabular}{ll|l}
2.4 PARTICIPANT SELECTION & 23
\end{tabular}

\begin{tabular}{|l|l|}
2.5 Data collection & 25
\end{tabular}

\begin{tabular}{ll|l}
2.6 Data analysis & 33
\end{tabular}

\begin{tabular}{|l|l|l|}
2.7 & Reflections & 34 \\
\hline
\end{tabular}

\begin{tabular}{|l|l|l|}
\hline 2.8 & Limitations & 35 \\
\hline
\end{tabular}

$\begin{array}{ll}2.9 \text { Summary } & 36\end{array}$

\section{3: Findings and Analysis}

\begin{tabular}{|l|l|}
\hline 3.1 Overview & 37 \\
\hline
\end{tabular}

\begin{tabular}{|l|l|}
\hline 3.2 Needs recognition & 38
\end{tabular}

\begin{tabular}{ll|l}
3.3 & Importance of need & 43
\end{tabular}

\begin{tabular}{|l|l|}
3.4 Motivation & 45
\end{tabular}

\begin{tabular}{ll|}
3.5 Current tools used & 50
\end{tabular} 
3.6 Current and anticipated challenges

3.7 Alternatives

3.8 Desired innovation/solution

\begin{tabular}{|l|l|}
\hline 3.8.1 Development of Simple Steps & 60
\end{tabular}

\begin{tabular}{|l|l|}
\hline 3.9 Validation of general attractiveness and desirability of Simple Steps & 62 \\
\hline
\end{tabular}

\begin{tabular}{|l|l|l|}
\hline 3.1 Clarification and validation of product attributes to develop & 64
\end{tabular} 0

3.1 Competitor Analysis

1

3.1 Business model strategy considerations

2

3.1 Summary of stakeholders' validation of market and product opportunities 3

\section{4: Discussion}

4.1 Summary of Business Model

4.2 Elaboration of business model components

4.3 Development of assumptions

4.4 Opportunities and barriers

4.5 What remains unknown and why 90

\begin{tabular}{|l|l|} 
4.6 Comparisons with previous research and similar products & 91
\end{tabular}

4.7 Implications beyond this research

Part Two starts on Page 95

\section{PART TWO - BUSINESS CASE AND RECOMMENDATIONS [CHAPTER 5 TO 9]}

\section{5: Business Model Design}

5.1 Overview of Simple Steps

5.1.1 Vision

5.1.2 Financial and social goals 98

5.2 Assumptions that were tested

5.3 Assessment of Opportunities and Constraints 100

5.4 Business Model Design Recommendations 101 


\section{6: MARKET VALIDATION AND DEVELOPMENT}

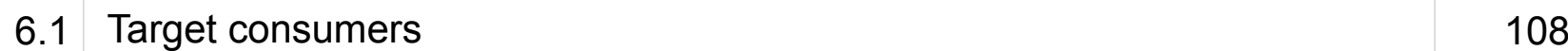

\begin{tabular}{|l|l|}
\hline 6.2 Where product adds value - why do consumers need Simple Steps? & 109
\end{tabular}

$\begin{array}{ll}\text { 6.3 Current solutions in market } & 110\end{array}$

$\begin{array}{ll}\text { 6.4 Market's reaction to Simple Steps } & 110\end{array}$

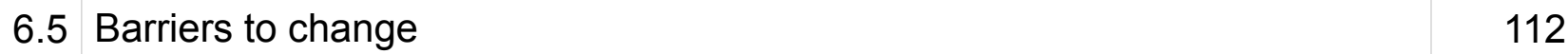

\begin{tabular}{l|l|}
\hline 6.6 Competitor Analysis & 113
\end{tabular}

\begin{tabular}{|l|l|l|}
\hline 6.7 & Positioning & 116 \\
\hline
\end{tabular}

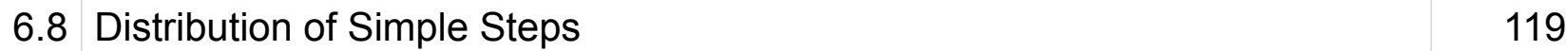

\section{7: PRODUCT VALIDATION AND DEVELOPMENT}

7.1 Product features needed and why

\begin{tabular}{l|l}
7.2 Development, testing and regulations & 126
\end{tabular}

\begin{tabular}{l|l|l|l|l|l}
\hline 7.3 & Manufacturing costs & 128
\end{tabular}

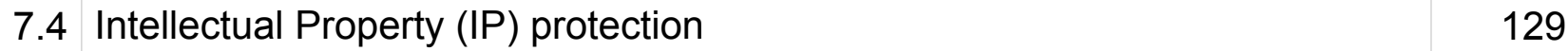

\section{8: RESOURCE REQUIREMENTS \& RETURNS}

\begin{tabular}{|l|l|l|l|}
\hline 8.1 & Skills required in HOMFI team & 133
\end{tabular}

\begin{tabular}{|l|l|}
\hline 8.2 Development and manufacturing process of Simple Steps & 135
\end{tabular}

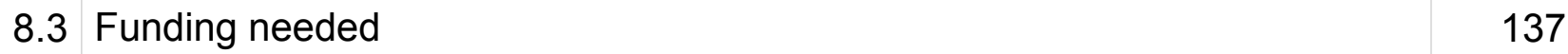

$\begin{array}{ll}\text { 8.3.1. Proposed funding plan } & 140\end{array}$

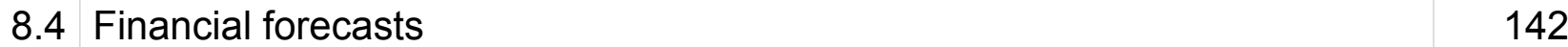

\begin{tabular}{|l|l|l|}
\hline 8.5 & Timeline of key activities & 143
\end{tabular}

9: Conclusion

\begin{tabular}{l|l|l|}
\hline 9.1 Recap of research & 145
\end{tabular}

$\begin{array}{ll}9.2 \text { Key outtakes and Implications } & 145\end{array}$

\begin{tabular}{|l|l|l}
\hline 9.3 & Future steps & 147
\end{tabular}

\section{Appendices}

Appendix 1.0: Information sheet 


\begin{tabular}{|l|r|}
\hline Appendix 1.1: Consent to interview & 152 \\
\hline Appendix 1.2: Consent to include photos in thesis & 154 \\
\hline Appendix 2.0: Stage 1 Questions for Seniors & 155 \\
\hline Appendix 2.1: Questions for Family Members & 157 \\
\hline Appendix 2.2: Questions for Healthcare professional & 160 \\
\hline Appendix 2.3: Questions for Government/Voluntary organisation & 161 \\
\hline Appendix 2.4: Stage 2 Questions for seniors & 163 \\
\hline Appendix 2.5: Question for Retirement Village managers & 165 \\
\hline Appendix 2.6: Questions for Designers/Engineers & 167 \\
\hline Appendix 2.7: Stage 3: ONLINE SURVEY & 168 \\
\hline
\end{tabular}




\section{List of Figures}

Figure

Page

Figure 1.1: Product innovation concepts explored with research participants 9

Figure 1.2: Maslow's Hierarchy of Needs 11

Figure 1.3: Consumer Decision Making Process Model 13

Figure 1.4: Business Model Canvas 14

Figure 2.1 Iterative research process 18

Figure 3.1: Overview of seniors (Total 23 interviewed) 38

Figure 3.2: Examples of step ladders currently used by seniors at home 50

Figure 3.3: Examples of step stools currently used by seniors at home 51

Figure 3.4: Initial product sketch 57

Figure 3.5: Product prototype of Simple Steps 61

Figure 4.1: Overview of Business Model Canvas (BMC) 77

Figure 5.1: Defining business ecosystems 102

Figure 6.1: Screenshot of step ladder review by Consumer NZ 113

Figure 6.2: Bailey step ladder 114

Figure 6.3: Ullrich step ladder 114

Figure 6.4: Screenshot of Nip-Glide webpage 118

Figure 6.5 Screenshot of SuperGold Card programme for businesses 122

Figure 6.6: Screenshot of SuperSeniors website promoting SuperCard offers 122

Figure 7.1 : Simple Steps prototype (now and future) 124

Figure 7.2: Screenshot from SGS website 127 


\section{List of Tables}

Tables

Page

Table 1.1: Outline of thesis structure

\begin{tabular}{|l|l|} 
Table 2.1 Summary of research design & 19
\end{tabular}

\begin{tabular}{|l|l|}
\hline Table 2.2: Summary of stakeholder assumptions & 21
\end{tabular}

\begin{tabular}{|l|l|}
\hline Table 2.3: Summary of participant selection & 23
\end{tabular}

\begin{tabular}{|l|l|}
\hline Table 2.4 Summary of open-ended questions for seniors & 25
\end{tabular}

\begin{tabular}{|l|l|}
\hline Table 2.5 Summary of questionnaire development for seniors & 28
\end{tabular}

\begin{tabular}{l|l} 
Table 2.6: Summary of questions for retirement village managers, designers & 30
\end{tabular} and engineers

\begin{tabular}{|l|l|l|l|l} 
Table 2.7: Summary of online survey development and questions & 31
\end{tabular}

\begin{tabular}{|l|l|}
\hline Table 2.8: Summary of data analysis methods & 33
\end{tabular}

\begin{tabular}{|l|l|}
\hline Table 3.1 Summary of tasks requiring access to high places & 38
\end{tabular}

\begin{tabular}{|l|l|l|} 
Table 3.2: Quotes from seniors which reflect frustrations & 41
\end{tabular}

\begin{tabular}{|l|l|}
\hline Table 3.3: Seniors' intention to move in the future & 43
\end{tabular}

\begin{tabular}{|l|l|} 
Table 3.4: Quotes from seniors relating to importance of need & 44
\end{tabular}

\begin{tabular}{|l|l|}
\hline Table 3.5: Application of SOC & 47
\end{tabular}

Table 3.6: Application of Maslow's hierarchy of needs: Access to high places as 48 a higher level need

$\begin{array}{ll}\text { Table 3.7: Current tools used } & 50\end{array}$

\begin{tabular}{l|l|l|l|l}
\hline Table 3.8: Alternative solutions & 53
\end{tabular}

\begin{tabular}{|l|l|} 
Table 3.9: Summary of preferred on product concept/solution & 55
\end{tabular}

\begin{tabular}{|l|l|} 
Table 3.10: Summary of views of sensor technology & 56
\end{tabular}

\begin{tabular}{|l|l|} 
Table 3.11 Importance of having a step ladder at home in three time periods. & 58
\end{tabular} 
Table 3.12: Scores awarded to each step ladder attribute based on level of importance

Table 3.13: Online survey respondents

Table 3.14: Tabulated responses to "Simple Steps looks appealing"

Table 3.15: Tabulated responses to "Simple Steps looks safe"

Table 3.16: Tabulated responses to "Simple Steps looks easy to use"

Table 3.17: Tabulated responses to "Simple Steps looks sturdy"

Table 3.18: Tabulated responses to preference for way sensor is incorporated within Simple Steps

Table 3.19: Tabulated responses to additional features willing to pay for

Table 3.20: Tabulated response to how Simple Step compares with what is available in the market

Table 3.21 Simple Steps - a product worth recommending?

Table 3.22: Key decision making considerations based on recurring comments from Stage $1 \& 2$ research

Table 3.23: Tabulated responses to "How likely will you buy Simple Steps at $\$ 100 ?$ “

Table 3.24 Tabulated responses to "How likely will you buy Simple Steps at Price at \$150?"

Table 3.25 Summary of stakeholders' validation of market and product opportunities

Table 4.1: Summary of Key Partners, Activities and Resources

Table 4.2: Customer relationship and segments

Table 4.3: Value Propositions

Table 4.4: Summary of cost structure and revenue implications

Table 4.5 : Summary of development of stakeholders assumptions

Table 4.6 : Summary of Opportunities and Barriers based on stakeholders 
Table 4.7: Summary of similar products that could be applied to Simple Steps' design philosophy

Table 5.1: Summary of HOMFl's financial and social goals

Table 5.2: Summary of opportunities and constraints based on research findings

Table 5.3: Summary of business model design recommendations

Table 5.4: Evaluation of the strengths and weaknesses of existing business models

Table 6.1: Brand positioning of HOMFI (Simple Steps)

Table 6.2: Summary of distribution strategy

Table 7.1: Types of IP protection in NZ

Table 7.2: Step ladder testing procedure

Table 8.1: Overview of team plan

Table 8.2: HOMFI Team in future

Table 8.3: Summary of development and manufacturing of Simple Steps

Table 8.4: Anticipated funding needed

Table 8.5: Proposed funding plan

Table 8.6: Break-even analysis

Table 8.7: Timeline of key activities 



\section{PART ONE: CONSUMER AND MARKET RESEARCH}

\section{CHAPTER 1: INTRODUCTION}

"The tragedy of old age is not that one is old, but that one is young" -- Oscar Wilde.

\subsection{Overview of project}

This is a research report on developing and commercialising assistive technology for the purpose of accessing high places at home. It aims to enable safety and independence for older consumers, set in the New Zealand context. Assistive technology is defined by Cowan \& Turner, as any tool that enhances ease and safety to support and maintain task performance which one would otherwise not be able to achieve (as cited in McCreadie \& Tinker, 2005). In the context of assistive technology for older adults, examples range from 'low-tech' simple aids such as walking sticks and frames (Edwards \& Jones, 1998) to 'high-tech' advanced home monitoring systems (Tinker, 2003). This chapter provides a background to the motivations behind this project, followed by specific research objectives and related opportunities. Next, it provides a discussion on the development of assistive technologies from an industry perspective, and also embodies a literature review on theories and frameworks that have guided the research.

\subsection{Inspirations and motivations}

As an eight year old child, I witnessed my grandfather attempting to fix a lightbulb while standing precariously on a ladder at home. I stood anxiously by the ladder, worried he might lose his balance, but he was adamant he would be fine. Twenty years later, a similar incident happened at home, with my parents. This time it was not the lightbulb, but an attempt to retrieve something from a high shelf. An offer of assistance was rebuffed, because what would their twenty-eight year old child know. I interpreted their resistance as a display of their desire for independence. Consequently, I would attribute this to be the "light-bulb" moment. I figured, the issue here was the risky tango between the need for independence and guarantees of safety, exacerbated by the inadequacies of current tools to access high places at home. Thus, I felt, if this was such a cause for concern for me, then this would be an opportunity to make things better; it was time to explore innovations to enable safer access to high places at home, particularly for ageing consumers. 
In a nutshell, the trepidation of senior family members attempting to reach high places at home propelled me to embark on this Master's project on Innovation and Commercialisation. As recommended by Kotler \& Keller (2005), product innovations should take a consumer-centric perspective where design considerations should be based on the needs and wants of the target market (i.e for this research, older customers). Thus, this research adopted a predominantly end-user (market-oriented) focus in the development of innovation and commercialisation strategies, set in the context of New Zealand's ageing population.

\subsection{1 "Successful ageing" movement}

As a self-directed researcher, I do not have an official project partner. However, this project is inspired by the movement of "Successful Ageing", advocating "cultural adaptation" in attitudes towards older people, and focusing on "discovering new ways of releasing age-specific potential" (Biggs, 2014, p.15). It is a campaign that encourages society to recognise that older people desire "a good life" that allows "personal agency" and "continuity in life patterns" (Schofield, Davey, Keeling \& Parsons, 2006, p. 278). In essence, it calls for a recognition of the positives that comes with an ageing population because older people will continue to be active participants of society, thereby creating opportunities for those who can anticipate their needs. In June 2018, New Zealand's Minster for Seniors, Tracey Martin, launched a renewal of a 2002 'Positive Ageing Strategy' that aims to "prepare for this maturing population", and suggests taking a "glass half-full" perspective on the issue, such as potential economic benefits (Vance, 2018). Consumers aged 65 and above are predicted to contribute $\$ 65$ billion to the spending economy by 2051 (Super Seniors, 2017).

A growing demand for smaller homes by older people is also an area I will explore as part of my research. This is based on my assumption that there will be greater need to utilise and access high places due to limited floor space in smaller houses. In research conducted by Davey (2006), a trend of downsizing in old age due to challenges of maintaining a large home and garden was revealed. As such, smaller houses "are generally preferred by older people" (Davey, 2006, p. 263). However, the New Zealand property industry appears to have neglected this demand. John Collyns, executive director of the Retirement Village Association, was quoted in a news article as saying, "The market has built big things and 
ignored the need for smaller homes" (Vance, 2018). As a result, there is a shortage of "smaller, accessible and adaptable housing...for older people" (Vance, 2018). This lack of anticipation and adaptation by industry players extends beyond property needs, and includes homewares and tools, such as solutions to access high places at home.

In a wider social and economic context, my research advocates seizing opportunities to adapt and cater to the needs of older consumers who want to age successfully. Therefore, any individual or organisation with the similar vision of supporting this movement towards Successful Ageing, and is interested in the development of technology for seniors, could potentially be a project partner in the future.

\subsubsection{Specific objectives of this research}

The objectives of this research project were to conduct a pilot study within the context of New Zealand:

1) To explore the needs, motivations, and challenges of access to high places at home among older people,

a) In order to develop innovations based on their needs and preferences to enable their safety and independence.

2) To develop and validate a business model to commercialise these innovations.

For the purpose of this research, innovation is defined as the development and implementation of better solutions that fulfil new or previously undiscovered/ unarticulated consumer needs. (Maranville, 1992).

\subsubsection{Opportunities related to my research:}

Opportunities related to this research can be illustrated through the Micro-MesoMacro framework. This framework enables perspectives from an individual or internal 'Micro' level, to the wider 'Meso' market or community environment, and finally, at a national or global 'Macro' context to identify commercial opportunities (Mason \& Harris, 2006). Here, I mainly describe opportunities taken from a social and economic perspective. 
Micro (specific individual needs): As part of "successful ageing", older individuals highly value independence (Garbriel \& Bowling, 2004; Godfrey, Townsend \& Denby, 2004) and "continuity in life patterns" (Schofield, Davey, Keeling \& Parsons, 2006, p. 278). Thus, they would likely want to continue engaging in activities that require access to high spaces at home. I further postulate that this need is important enough for older consumers to invest in a better tool than what is currently available (due to risks of falls). Hence, an opportunity to develop and commercialise an innovation exists.

Meso (market/social environment) : Current tools for access to high places at home are not ergonomically designed for older people and can be improved and made safer, especially to prevent falls. Ergonomics is defined here as designing things with "deliberate efforts" to accommodate users "in order to make [their] daily life and performance of tasks safe, efficient, and easy." (Kroemer, 2006, p.2). This absence of ergonomically designed tools presents opportunities for innovation.

Concurrently, there is an assumption that the people and communities around older people are concerned about the safety of current tools, respect their need for independence and, therefore, would be supportive of a better solution to help them continue with this activity. In addition, family members or care-givers of older people might be willing to recommend or purchase such tools for them to enable their safety and independence.

Macro (national trends and beyond): In 2016, New Zealand's Accident Compensation Corporation (ACC) announced a $\$ 30$ million investment aimed at reducing "falls and fractures for older New Zealanders" where funds will be channelled towards related programmes including "home safety assessment and intervention" (Beehive Government Press Release, 2016). Within the context of ACC, falls are also the "most common and costly cause of injury" for older people (Health Quality \& Safety Committee New Zealand, 2016). By 2025, it is expected that fall-related claims for seniors could cost the New Zealand government $\$ 418$ million annually (Health Quality \& Safety Committee New Zealand, 2016). 
Although there are no specific statistics indicating the number of falls caused by accessing high places at home among seniors, it would be reasonable to assume that falls do occur from such attempts, for example through the use of a ladder at home. In 2017, the total cost to ACC for ladder-related home injuries alone among older people (aged above 60 ) was approximately NZ\$4.7 million, with a total claim count of 6045 (ACC Statistics, 2018). This demonstrates an opportunity to explore safer solutions in relation to ladder improvements or alternatives among seniors.

\subsection{Proposed development strategy and business model}

In accordance with my research objectives, the proposed development strategy was to understand underlying needs, motivations and expectations of older consumers in order to develop innovations they desire. The project aimed to develop and pilot test innovation concept(s) in consultation with research participants. As part of this strategy, this research incorporated a methodology that allowed a range of potential ideas to be explored, enabling development of the innovation to be guided by participants. Reflective of this explorative strategy, the proposed business model is based on a customer-centric philosophy of "co-creation", defined as an emphasis for companies to not only understand consumer needs, but to collaborate with customers to create better innovation (Saarijärvi, 2012).

\subsection{Review of assistive technology in the industry}

In this section, I will discuss perspectives that has guided innovations of assistive technology for older consumers, while providing examples of both developing and commercialised products. Thereafter, I will elaborate on the product innovation concepts that were explored as part of this research.

\section{Innovations for inclusiveness}

Inclusive design is closely tied to earlier defined concept of ergonomics (refer p. 15). Fundamentally, it is ensuring and enabling confident and independent participation of everyday activities by everyone (Clarkson \& Coleman, 2015). Although this research specifically focuses on innovations to enable safe assess to high places at home, the issue has to be considered in a wider context of the home environment for a deeper understanding of the topic. 
Earlier in the chapter, I have established the importance of independence among seniors. However, physiological declines with age affect the ability for older people to remain safe and independent in their own homes (Marsiske et al, 1999; Birren \& Schaie, 2006). Consequently, innovations within the home environment that address such age-related physiological challenges should be implemented (Kelly, Fausset, Rogers \& Fisk, 2014).

In 2017, a project aimed at addressing the needs of an ageing population supporting independence at home through the development of inclusive innovations was spearheaded by Turkish bathroom specialist brand, VitRa and Sheffield Hallam University's Lab4Living (Seemann \& Barron, 2017). Lab4Living is a team of crossdisciplinary researchers who focus on "developing products, services and interventions that promote dignity and enhance quality of life" (Sheffield Hallam Univerisity Lab4Living, n.d). The project outcome was a research-focused publication of "a guide on inclusive bathroom design" where design considerations relating to an older person's physical strength, grip, vision, hearing and balance were set out (Vitra \& Sheffield Hallam University Lab4Living, 2017).

A key takeaway from this guide is the importance of designing for adaptability, due to evolving needs with age, so as to enable independence for as long as possible (Seemann \& Barron, 2017). It also highlights the benefits of a collaborative partnership between academia and industry.

\section{Incremental or radical innovation?}

The commercial success of innovation is dependent on consumer acceptance. Research has defined consumer acceptance as part of an emotional process that is related to goal achievement (Bagozzi \& Lee, 1999). Therefore, in order for innovation to be accepted and utilised by older people, it is crucial to understand the eventual goals of seniors in their task performance. Studies have shown low acceptance of assistive technology they find unfamiliar with and are high in technology, even if they acknowledge advanced technology is beneficial (Chen \& Chan, 2011).

The categorisation of product innovations as incremental or radical, which depends on the degree of design novelty (Mugge \& Dahl, 2013), would be applicable in this discussion. A concept with minimal deviation from the current design state of a product category i.e low 
novelty, would be considered an incremental innovation (Mugge \& Dahl, 2013).

Concurrently, a design with substantial to complete deviation from present solutions i.e high novelty, would be viewed as a radical innovation (Mugge \& Dahl, 2013).

\section{Incremental innovation}

Looking within the context of New Zealand, an example of an incremental innovation catered to older consumer is the launch of "Senior phone" by telecommunications provider, 2degress, in 2012. The touted selling points of this phone included "extralarge talking buttons" and "SOS emergency text buttons" (2degrees, 2012). Essentially, this is a similar product to a standard mobile phone, but with additional incremental innovation catered to the potential needs of older consumers.

\section{Radical innovation}

At the extreme end of radical innovations, industry players have been fervent in their pursuit of robotic technologies to aid mobility issues. For example, exoskeletons (robotic suits) are currently being developed and have been touted as solutions for older consumers to overcome physical limitations (Brewster, 2016). However, whether such advanced technologies will be acceptable to older consumers have not been substantiated in extant studies.

There is also much interest in the development of health monitoring and fall detection devices as means to maintain well-being of older people (Liu, Stroulia, Nikolaidis, Miguel-Crus \& Rincon, 2016). I consider such innovations radical because (as of current knowledge) they are typically available in the consumer market as a new product type or form, instead of being integrated into existing devices.

Such products are available in the commercial market. One example is a device by multinational technology company, Philips, with a device known as Philips LifeLine with AutoAlert (Philips Lifeline, 2018). This is a product that comes as a wearable (pendant) that automatically detects falls, and calls for help using "patented technology that constantly measures changes in height orientation to a horizontal position and velocity" (Philips Lifeline, 2018). A similar example by a New Zealand 
based company, Chiptech, is a fall detection pendant known as Pearl Advanced Pendant (Chiptech, 2018).

\section{Low to high tech innovations to access high places at home}

The review of the current assistive technology industry highlights several key takeaways which served as guiding points for the research. Firstly, the end goal of this project is to enable inclusiveness in tools designed for older people. Secondly, this research aimed to explore the acceptance of product innovation from low novelty (simple technology) to high novelty (advanced technology). The following Figure 1.1 shows the range of low to advanced technology innovation concepts (in related to accessing high places at home). These possible solutions were explored as part of the research process (elaborated in the Methodology chapter) before coming to a conclusion on the final product concept to pursue. Lastly, the acceptance of sensors for health monitoring and fall detection as part of the solution (to enhance safety) was explored. 
Figure 1.1: Product innovation concepts explored with research participants

Referring to Figure 1.1, the product innovation concepts that were explored with research participants are as follows:

1. Step ladder with additional side and top handles (Easylife Group, 2018).

2. A cycle lift that could propel a person vertically inspired by a Royal College of Art vertical transportation system (Morris, 2017).

3. A mini powered lift (small enough for home use).

4. A robotic exoskeleton suit that enables humans to achieve mobility breakthroughs (Brewster, 2016). 
5. Bringing things down in from the form of drop-down shelves. However, this idea is limited to accessing storage space and was explored as a secondary/ complementary concept.

\subsection{Literature Review}

\section{Independence}

The concept of independence is key to this research. It has various definitions including personal, emotional and social perspectives (Sixsmith, 1986). On a personal level, independence is defined as being to manage oneself (Peek, 2017). Emotionally, independence refers to autonomy and freedom to decide on what one wants to do (Ball, Perkins, Whittington, Hollingsworth, et al., 2004). Taken in a social context, independence involves not feeling obligated to others such as family members or the community (Peek, 2017).

The complexity of independence supports the significance of performing home tasks among older people, which include domestic activities that require access to high places at home (Coleman, Kearns \& Wiles, 2016). What is not known is how important this need is and underlying motivations behind it. Therefore, this research aimed to contribute to this knowledge gap.

\section{Baltes' theory of Successful Ageing}

Baltes' theory of Selection, Optimisation and Compensation (SOC) discusses methods of ensuring independence for successful ageing through on-going adaptive behaviour (Donellan, 2015). Although this is a theory applicable to the process of ageing throughout one's life course, it is particular beneficial in the discussion of ageing for older adults (Donellan, 2015). In essence, the processes of selection, optimisation, and compensation are continuous adaptive means to maximise gains and minimise losses that one experiences during the course of ageing (Freund, 2005). To elaborate, selection is a process of narrowing the number of goals that remain important to a person due to evolving limitations, as well as a "reconstruction of one's goal hierarchy or the search of new goals" (Freund \& Baltes, 1998, p. 531). Optimisation refers to the achievement of higher level goals through "the allocation and refinement of internal or external 
resources" (Freund \& Baltes, 1998, p. 531). Compensation attempts to retain certain abilities to engage in the same activity even with the knowledge of decline, by means of substitution (Donellan, 2015).

Based on the SOC model, the adoption of assistive technology is reflective of how one could adapt to the losses of ageing in order to maximise gains for successful ageing (Donellan, 2015).

\section{Maslow's hierarchy of needs}

To understand successful ageing within the context of consumer behavior, I selected Maslow's Hierarchy of Needs as a theoretical framework to further explore whether the task of accessing high places could be attached to higher level needs among older people. Maslow's theory presents human motivation on a hierarchy, where once lower needs are satisfied, one moves on to the next higher level of need (Schifman, Bednall, O'Cass, Paladino \& Kanuk, 2005). Figure 1.2 illustrates the different levels of need.

Figure 1.2: Maslow's Hierarchy of Needs

\section{REDACTED}

This hierarchical process is not linear and could involve one moving "back and forth between needs over time, depending on circumstances" (Thielke, Harniss, Thompson, Patel, Demiris \& Johnson, 2012, p. 474). This constant movement between different levels of need reflects similarity to the concept of continuous adaptation in Baltes' SOC theory. 
Although Maslow's theory have been questioned in literature, it remains a widely adopted framework in both academia and the commercial arena (Thielke et al, 2012). Some studies have also demonstrated relevance of Maslow's theory in the adoption of healthrelated technologies among older adults (Copelton, 2010; Neven, 2010). Therefore, for the purpose of this research, I consider Maslow's theory as a useful and relevant concept in understanding consumer behaviour of older people.

\section{Consumer decision-making process (CDMP) model}

The eventual goal of this research is to develop innovations that will be accepted and purchased by older consumers, thus leading to commercial success. Hence, it is important to consider factors that contribute and affect the process of consumer decisionmaking. Therefore, the Consumer Decision-Making Process Model (refer to Figure 1.2) was utilised as a basis for research design. The CDMP model is a marketing framework that identifies how consumers journey from the initial stage of need recognition to the act of purchase (Schifman et al, 2005). For the scope of this project, particularly focus (with reference to Figure 1.2) was placed on exploring need recognition, motivation and some aspects of social-cultural environment, in order to develop strategies for product, promotion, price and channels of distribution. 


\section{REDACTED}

\section{Stakeholder theory}

In relation to research sample, participants were selected based on Stakeholder Theory, which identifies the types of people or organisations that could contribute value to a business (Freeman, Rusconi, Signori \& Strudler, 2012). As illustrated by the CDMP model (refer to Figure 1.2), the consumer decision-making process is affected by external factors and involves other individuals or organisations. Further details would be further discussed in Chapter 2. 


\section{Business Model Canvas}

Lastly, I utilised the Business Model Canvas, which is a strategic management tool widely used in the commercial world to map out the blueprint of a feasible business model (Osterwalder \& Pigneur, 2010). Further details would be further discussed in Chapter 2.

Figure 1.4: Business Model Canvas

\section{The Business Model Canvas}

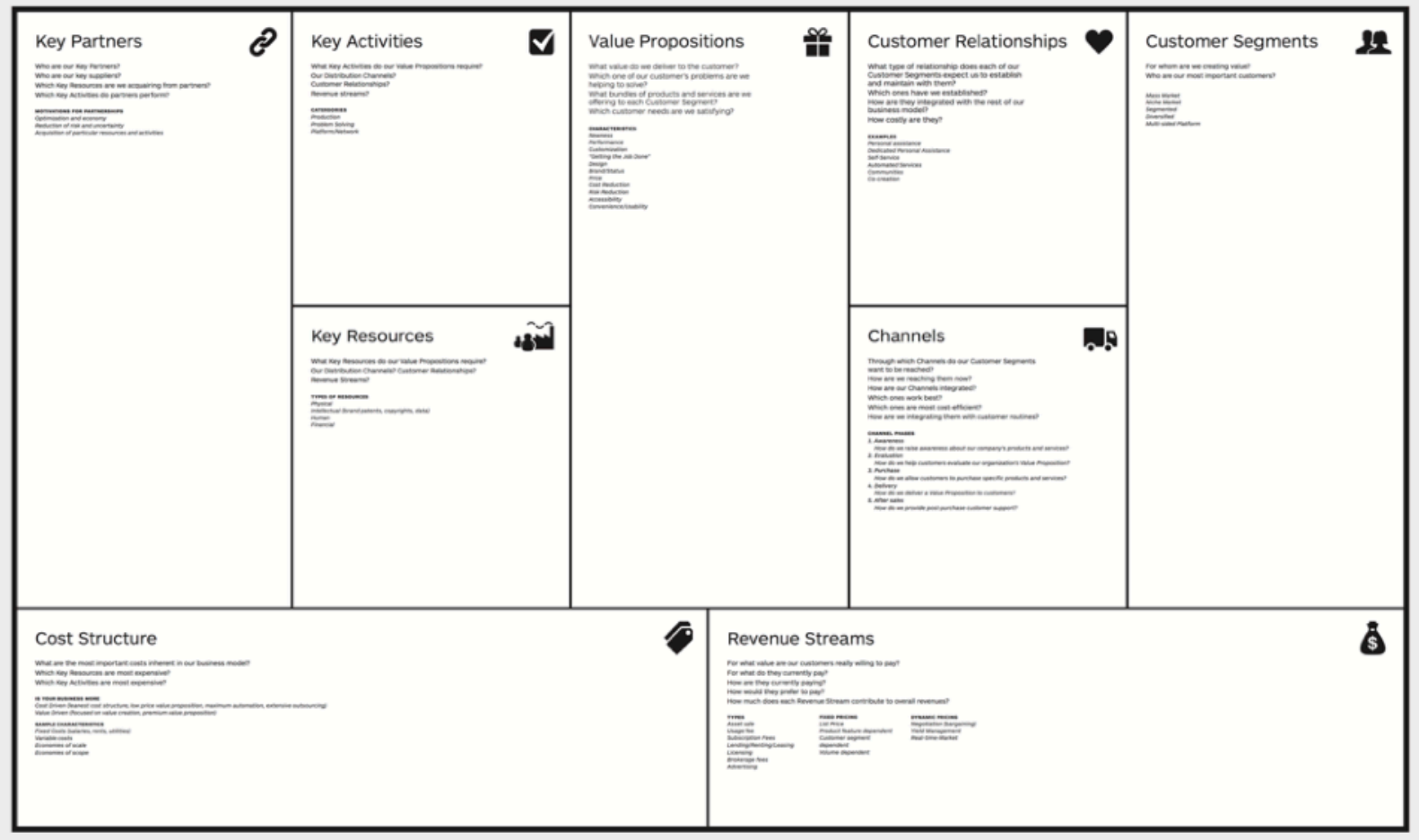

\subsection{Scope of research: Limitations and future investigations}

Due to time and resource constraints, this research is limited in scope in geography and physical product development. The findings of primary research is limited to Wellington, New Zealand. It was not within the scope of this project to develop a functioning product prototype for consumer testing, however, a realistic visual product representation was developed and validated through an online survey. Although this report is limited to New Zealand, the formulation of the methodology of this research was done with the consideration that this study could be adapted and replicated in other countries with an ageing population such as Singapore, in order to access overseas opportunities. Hence, 
the research was designed with a relatively clear structure grounded by ageing concepts and business frameworks, with the assumption that these ideologies are applicable in different contexts.

As this research was embarked when the idea was at an explorative stage, it was not feasible to expect that a product be produced or a business be set up. However, within reasonable means, I have presented the case and recommendations for a product and technology innovation, and also set out the potential strategies to commercialise the major innovations discussed in this thesis. The next steps, would be to further refine the product concept, and look into finding the right team to develop the product, and raise funds where necessary. These steps would be further elaborated in the Business Case (Part Two of this report).

\subsection{Summary of research and outline of thesis}

In summary, the research project is: Firstly, an explorative consumer behaviour study of older people in relation to their needs and motivations of accessing high places at home. Secondly, an evaluation of innovation and commercialisation opportunities that arise from this need. A combination of ageing, consumer marketing and business theories have been applied to the research, in order to explore the business model, market, product, resource requirements of the project. Due to the iterative nature of this research, the structure of this thesis deviates from a conventional format. Table 1.1 below provides an outline of the thesis. 


\begin{tabular}{|c|c|c|}
\hline Part & Chapter & Description \\
\hline \multirow[t]{4}{*}{ ONE } & 1: Introduction & $\begin{array}{l}\text { Provides an overview of the research including } \\
\text { inspirations, motivations, opportunities and related } \\
\text { technologies and relevant literature. }\end{array}$ \\
\hline & 2: Methodology & $\begin{array}{l}\text { Justifies and elaborates on the qualitative methodology } \\
\text { of the research. Includes assumptions made as part of } \\
\text { the research questions and key-decision making factors } \\
\text { in the research design. Provides details on participant } \\
\text { selection, as well as how data was collected and } \\
\text { analysed. }\end{array}$ \\
\hline & $\begin{array}{l}\text { 3: Findings and } \\
\text { analysis }\end{array}$ & $\begin{array}{l}\text { Presents data collected from research and relevant } \\
\text { analysis. This chapter focuses on presenting and } \\
\text { highlighting market and product development } \\
\text { opportunities, while teasing out relevant information for } \\
\text { business model implications. A product prototype is } \\
\text { revealed in this chapter. }\end{array}$ \\
\hline & 4: Discussion & $\begin{array}{l}\text { Based on information from Chapter 3, a potential } \\
\text { business model using the Business Model Canvas is } \\
\text { presented. Further analysis of information within the } \\
\text { Business Model Canvas framework is discussed. This } \\
\text { chapter also includes implications beyond the scope of } \\
\text { this research that could be relevant to future } \\
\text { commercialisation opportunities. }\end{array}$ \\
\hline TWO & $\begin{array}{l}5 \text { to } 8 \text { : Business } \\
\text { case and } \\
\text { recommendations }\end{array}$ & $\begin{array}{l}\text { Consolidates information from Chapters } 3 \text { and } 4 \text { and } \\
\text { provides a further development of business model. } \\
\text { Additional discussion of key research takeaways with a } \\
\text { commercial focus is presented and some new } \\
\text { information will be included. These chapters lay out } \\
\text { immediate and future plans and recommendations to } \\
\text { achieve commercialisation. This is meant to read as an } \\
\text { independent document, hence some parts may be } \\
\text { repetitive. }\end{array}$ \\
\hline
\end{tabular}




\begin{tabular}{|c|c|c|}
\hline Part & Chapter & Description \\
\hline & 9: Conclusion & $\begin{array}{l}\text { Summarises the research project and provides key } \\
\text { outtakes and implications for future development. This } \\
\text { chapter also outlines next steps for the project. }\end{array}$ \\
\hline
\end{tabular}

The report also includes a reference list and appendices after the Conclusion chapter. 


\section{CHAPTER 2: METHODOLOGY}

\subsection{Overview}

The research methodology took on an iterative process, as show in Figure 2.1 below.

Figure 2.1: Iterative research process

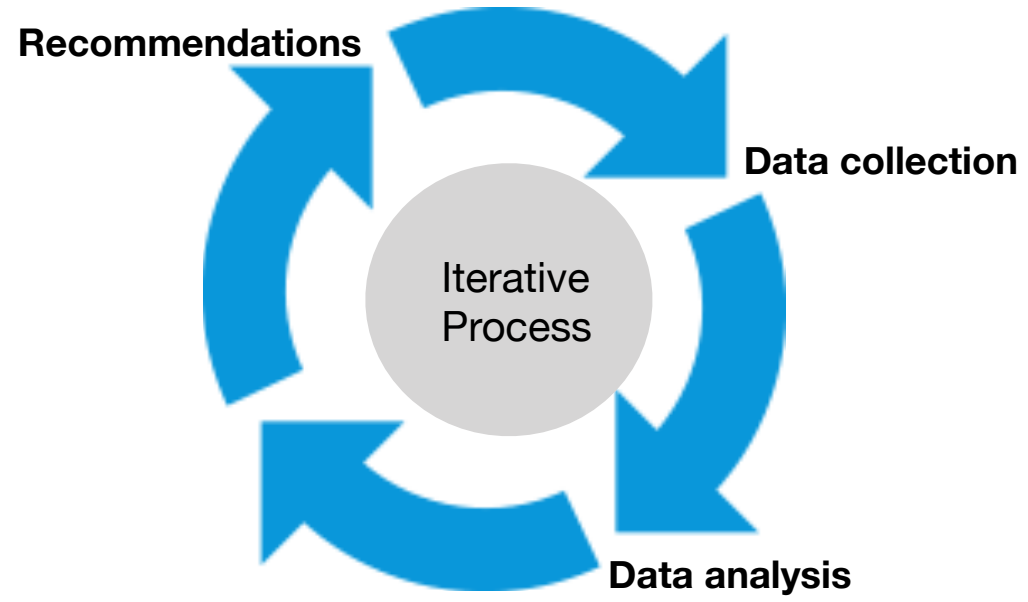

For clarity of presentation, the methodology design is presented in four main stages. My research focus was predominantly qualitative with minor quantitative components. I will steer away from calling this mixed-method research, as I placed a strong emphasis on employing qualitative methods from the beginning, while the decision to adopt quantitative tools evolved as a result of the iterative framework. Table 2.1 summarises my research design. A total of 40 people representing different participant categories took part in this research (i.e Seniors, Family members, Healthcare professionals, Retirement Village managers, Organisation representatives, Engineers and Designers). 
Table 2.1 Summary of research design

\begin{tabular}{|c|c|c|c|}
\hline Stage & Method & $\begin{array}{l}\text { Theoretical } \\
\text { framework }\end{array}$ & Participant category \\
\hline 1 & $\begin{array}{l}\text { Semi-structured, face to face } \\
\text { interviews } \\
\text { (explorative questions) } \\
{ }^{*} \text { Range of product concepts } \\
\text { presented }\end{array}$ & \multirow[t]{3}{*}{$\begin{array}{l}\text { Grounded } \\
\text { Theory }\end{array}$} & $\begin{array}{l}\text { Seniors }(n=18) \\
\text { Family }(n=4) \\
\text { Healthcare professionals }(n=4) \\
\text { NGOs and Government }(n=3)\end{array}$ \\
\hline 2 & $\begin{array}{l}\text { Semi-structured, face to face } \\
\text { interviews } \\
\text { (mix of explorative and } \\
\text { focused questions) } \\
\text { *Initial product sketch } \\
\text { presented }\end{array}$ & & $\begin{array}{l}\text { Seniors }(n=5) \\
\text { Retirement village manager } \\
(n=2) \\
\text { Engineer/Designer }(n=4)\end{array}$ \\
\hline 3 & $\begin{array}{l}\text { Online survey } \\
\text { (mainly closed questions) } \\
\text { *Product prototype } \\
\text { presented }\end{array}$ & & $\begin{array}{l}\text { Representation from all } \\
\text { participants }(n=21)\end{array}$ \\
\hline 4 & $\begin{array}{l}\text { Business Model Canvas } \\
\text { Analysis }\end{array}$ & $\begin{array}{l}\text { Business } \\
\text { Model } \\
\text { Canvas }\end{array}$ & N/A \\
\hline
\end{tabular}

\subsection{Assumptions (Research paradigms and frameworks)}

\section{Philosophical assumptions}

My research objectives essentially aim to understand the underlying needs, motivations and challenges of stakeholders, particularly end-consumers (older people), with regard to the issue of accessing high places at home. This is conducted with the aim of formulating a business strategy that will maximise the commercial success of relevant innovation(s). With the consideration that stakeholders would hold different perspectives, this strongly suggests employing a social constructionist viewpoint. A social constructionist viewpoint makes the "assumptions that there is no absolute truth" and that "reality is self and socially 
constructed by people ascribing meanings to make sense of the world" (Easterby-Smith, p. $63,2008)$.

It was necessary to adopt a qualitative methodology that allowed rich, in-depth discussions with research participants. A quantitative method would not be able to provide comprehensive understanding of consumer behaviour which is critical for this research. Furthermore, time and resource constraints would have prevented the surveying of large samples making it impossible to yield results of statistical significance.

My methodology was based by grounded theory, defined as a qualitative approach of "the discovery of emerging patterns in data" using a systematic process of data collection and analysis (Wash, Holton, Fernandez, Levina \& Glaser, 2015, p. 593). This is aligned with the explorative, non-prescriptive and iterative nature of this research, while providing a methodical framework. Through this methodology, it was expected that themes and phenomena would be observed that would guide the development of the product innovation and business model.

\section{Conceptual assumptions and research methodology questions}

The conceptual assumptions of Baltes' Theory of Successful Ageing (SOC), as well as Consumer Behaviour theories of motivation and consumer decision-making process model helped define the questions that were posed to research participants. These conceptual assumptions also guided the data analysis process.

\section{Business strategy assumptions}

The methodology design also revolved around validating the assumptions of the research questions as follows:

1) The assumption that there is a consumer need (market and product opportunities) for innovation, in relation to tools for accessing high places at home.

2) The assumption that there is potential to create and develop a successful business arising from this innovation (i.e a viable business model).

In particular, stakeholder theory defined the research participants, prioritised who to interview and the type of questions to ask. There was an assumption that all stakeholders would be somewhat supportive of the idea of developing innovations for safer access to high places at home, in order for the research to progress. Hence, a major aspect of the 
research sought to validate the following assumptions. Table 2.2 provides a summary of these stakeholder assumptions that guided research design.

Table 2.2: Summary of stakeholder assumptions

\begin{tabular}{|c|c|c|}
\hline $\begin{array}{l}\text { Stakeholder } \\
\text { category }\end{array}$ & $\begin{array}{l}\text { Participant } \\
\text { category }\end{array}$ & Assumptions to test \\
\hline $\begin{array}{l}\text { End } \\
\text { consumers }\end{array}$ & Seniors & $\begin{array}{l}\text { Seniors have a need for innovation and are } \\
\text { willing to purchase the new product. }\end{array}$ \\
\hline \multirow[t]{2}{*}{ Enablers } & $\begin{array}{l}\text { Government and } \\
\text { voluntary } \\
\text { organisation }\end{array}$ & $\begin{array}{l}\text { A certain level of support (whether financial or } \\
\text { non-financial) would be available from these } \\
\text { organisation to facilitate successful product } \\
\text { development and commercialisation. }\end{array}$ \\
\hline & $\begin{array}{l}\text { Engineers and } \\
\text { designers. }\end{array}$ & $\begin{array}{l}\text { Technological suppliers (engineers and/or } \\
\text { designers) are able to produce the innovation. }\end{array}$ \\
\hline Intermediaries & $\begin{array}{l}\text { Retirement village } \\
\text { managers }\end{array}$ & $\begin{array}{l}\text { Retirement villages could be part of the } \\
\text { distribution channel, bringing the product to end } \\
\text { consumers i.e. their residents who are the } \\
\text { potential end consumers. }\end{array}$ \\
\hline \multirow[t]{2}{*}{ Influencers } & $\begin{array}{l}\text { Family members } \\
\text { (of seniors) }\end{array}$ & \multirow{2}{*}{$\begin{array}{l}\text { Influencers support the product and/or are } \\
\text { willing to endorse and/or recommended the } \\
\text { product to consumers. }\end{array}$} \\
\hline & $\begin{array}{l}\text { Healthcare } \\
\text { professionals }\end{array}$ & \\
\hline
\end{tabular}

\subsection{Decision-Making Factors In Research Design}

Key factors in the decision-making process were also influenced by the criteria of accessibility, accuracy and adaptability (Easterby-Smith, 2008).

Accessibility: This was evaluated based on whether the method allowed accessibility to participants in a quick and economical manner. To manage time and resource constraints, I employed non-random sampling by utilising existing networks and employed a snowballing technique (O’leary, 2005). 
Accuracy: To minimise bias and maximise reliability of collected data, structural and disciplined approaches were employed in both data collection and analysis. As indicated in the four stages of the research process, this involved a systematic development of 1) semi-structured interviews with a wider group using explorative questions, 2) semistructured interviews with a smaller group using focused questions, and 3) a standard online survey presented to all interviewed participants as a means to further validate findings from the previous interviews. 4) Consolidating information in the Business Canvas Model served as a final validation of the primary data collected. Information gaps were identified and further secondary research was conducted.

In the first two research stages, I decided on face-to-face interviews as they would enable me to observe nuances (e.g body language, tone of voice) that would add depth to the research. At the same time, I administered a final online survey in stage 3 to remove personal bias that might be present in a face-to-face interview when it came to gathering feedback for the finalised product concept.

Adaptability: This research is intended to be a pilot investigation of a project that could have international potential. Therefore, the research design has to satisfy both structure and flexibility, in order to be adapted for future explorations in other countries. This is also the reason to adopt a semi-structured approach at the start of data collection. Semistructured interviews (as opposed to fully structured or open interviews) would allow a good mix of structure and flexibility to conduct the interviews in a time-efficient and guided manner, without sacrificing potential exploratory opportunities. The Business Canvas Model was chosen for its adaptability and easy application to a wide range of industries.

\section{Ethical considerations.}

Obtaining informed consent was of upmost importance in the research design consideration. This was ensured by giving participants the opportunity to consent or reject being involved with this project before the start of each interview. An information sheet (refer to appendix 1.0) describing and explaining my project was given to all participants in order to ensure they received sufficient information to make an informed decision. This was followed by giving all participants a consent form (refer to Appendix 1.1), in which they indicated their approval or disapproval of their participation in the study. As request for photography was involved for some of the participants (to photograph current tools they 
use at home), a separate form as indicated in Appendix 1.2 was provided to seek permission. All forms were granted approval from the Human Ethics Committee of Victoria University of Wellington on the date of 1 August 2017.

Confidentiality was also an important ethical consideration. It has been ensured that all data collected for this research was confidential by not using any names in the report. All interview data will be destroyed 1 year after research.

\subsection{Participant Selection}

As earlier indicated, participants were selected based on stakeholder theory. The following table 2.3 summarises the participant selection process.

Table 2.3: Summary of participant selection

\begin{tabular}{|c|c|c|}
\hline Participant & Selection criteria & Breakdown \\
\hline Seniors & $\begin{array}{l}\text { Dwelling type: } \\
\text { Retirement Village (independent style } \\
\text { residences) or Living in Community; } \\
\text { Apartment or House } \\
\text { - Age range ( } 60 \text { to } 90 \text { years old) } \\
\text { - Views from both genders } \\
\text { - Seniors living alone or with } \\
\text { someone }\end{array}$ & $\begin{array}{l}\text { Retirement village }(n=13) \\
\text { Community }(n=10)\end{array}$ \\
\hline $\begin{array}{l}\text { Family } \\
\text { Member }\end{array}$ & $\begin{array}{l}\text { - Age range } \\
\text { - Daughter or son relationship with } \\
\text { senior }\end{array}$ & $\begin{array}{l}\text { Age of family member: } \\
\text { 30s; Son }(n=1) \\
\text { 40s; Daughter }(n=1) \\
\text { 50s; Daughter }(n=1) \\
\text { 60s; Daughter }(n=1)\end{array}$ \\
\hline $\begin{array}{l}\text { Healthcare } \\
\text { profession } \\
\text { al }\end{array}$ & $\begin{array}{l}\text { Range of occupation that would have } \\
\text { interaction with seniors, especially in } \\
\text { relation to mobility issues }\end{array}$ & $\begin{array}{l}\text { Nurse }(n=1) \\
\text { Physiotherapist }(n=1) \\
\text { Occupational therapist }(n=2)\end{array}$ \\
\hline
\end{tabular}




\begin{tabular}{l|l|l}
\hline Participant & Selection criteria & \multicolumn{1}{l}{ Breakdown } \\
\hline $\begin{array}{l}\text { Voluntaryl } \\
\text { Governme } \\
\text { nt }\end{array}$ & $\begin{array}{l}\text { Organisations advocating rights of older } \\
\text { people }\end{array}$ & $\begin{array}{l}\text { Voluntary }(n=1) \\
\text { Government }(n=2)\end{array}$ \\
\hline $\begin{array}{l}\text { Engineerl } \\
\text { Designer }\end{array}$ & $\begin{array}{l}\text { Academic and commercialisation } \\
\text { experience }\end{array}$ & Engineer $(n=2)$ \\
\hline $\begin{array}{l}\text { Retiremen } \\
\text { t village } \\
\text { manager }\end{array}$ & Two different retirement villages & Designer $(n=2)$ \\
\hline
\end{tabular}

\section{Seniors}

Seniors living in independent style units within retirement villages and the community were recruited. This is based on an assumption that those living in independent type dwellings within a retirement village have similar needs to those living in the community. If validated, this also validates the assumption that retirement villages could serve as potential intermediaries. Further selection criteria such as age range (representation from "young old" to "older old"), gender and whether senior lived alone or with someone were included.

\section{Family members}

Family members from a range of ages were sought, in order to mirror the age-spread of the seniors being interviewed.

\section{Healthcare professionals:}

Different professionals were sought to gain a more comprehensive picture of their roles as potential influencers of seniors. As different healthcare personnel interact with patients in different settings, they might attribute different priorities to the same issue.

\section{Government and voluntary organisations}

Both viewpoints from government and voluntary organisations were sought to understand how much of a role they could play in the support and facilitating of product and business development. 


\section{Engineer/Designer}

Perspectives from both engineers and designers were included to gain insights into different aspects of product development possibilities and constraints. Designers tend to focus on the integration of aesthetics into product functionality, while engineers tend to have stronger knowledge of technical and manufacturing constraints. As this project has both an academic and commercial focus, the decision to seek designers and engineers with academic and commercial experience was made.

\section{Retirement Village managers}

Two managers from different retirement villages were interviewed for data richness.

\subsection{Data Collection}

\section{Stage 1: Semi-structured interviews (approximately 40 minutes per interview)}

\section{Participants recap (refer to Table 2.1): Seniors, Family members, Healthcare} professionals and Voluntary and Government organisations

Interview guides were developed for different participant categories. In this stage of the research the questions were explorative and mostly open questions. The questions at this stage delved into understanding the emotive side of things and employed laddering techniques, which probes the interviewees to reveal potential previously unarticulated higher-order needs (Reynold \& Gutman, 1988).

The following Table 2.4 provides a brief overview of the key questions for seniors:

Table 2.4 Summary of open-ended questions for seniors (Refer to Appendix 2.0)

\begin{tabular}{|c|c|c|c|}
\hline $\begin{array}{l}\text { To validatel } \\
\text { inform: }\end{array}$ & Question development & $\begin{array}{l}\text { Question type and } \\
\text { description }\end{array}$ & $\begin{array}{l}\text { Qn. } \\
\text { no. }\end{array}$ \\
\hline $\begin{array}{l}\text { Market need } \\
\text { and } \\
\text { opportunities }\end{array}$ & $\begin{array}{l}\text { Validate need of accessing } \\
\text { high places at home, } \\
\text { understand its importance } \\
\text { and underlying motivations. }\end{array}$ & $\begin{array}{l}\text { Tasks requiring access to high } \\
\text { places at home, frequency, } \\
\text { importance to continue doing } \\
\text { it and the reasons. }\end{array}$ & 1,6 \\
\hline
\end{tabular}




\begin{tabular}{|c|c|c|c|}
\hline $\begin{array}{l}\text { To validate/ } \\
\text { inform: }\end{array}$ & Question development & $\begin{array}{l}\text { Question type and } \\
\text { description }\end{array}$ & $\begin{array}{l}\text { Qn. } \\
\text { no. }\end{array}$ \\
\hline & $\begin{array}{l}\text { Understand consumer } \\
\text { dissatisfactions and potential } \\
\text { concerns regarding current } \\
\text { tool in order to identify } \\
\text { product innovation } \\
\text { opportunities. }\end{array}$ & $\begin{array}{l}\text { Tool(s) used to access high } \\
\text { places at home and } \\
\text { associated challenges and } \\
\text { risk concerns (either now or } \\
\text { anticipated) in using tool. }\end{array}$ & $\begin{array}{r}2,3 \\
5\end{array}$ \\
\hline & $\begin{array}{l}\text { Explore communication gaps } \\
\text { between older people and } \\
\text { their family members, so as } \\
\text { to identify potential } \\
\text { unawareness of need by } \\
\text { family members. }\end{array}$ & $\begin{array}{l}\text { Willingness to communicate } \\
\text { difficulties to family members }\end{array}$ & 4 \\
\hline \multirow[t]{3}{*}{$\begin{array}{l}\text { Product } \\
\text { development } \\
\text { opportunities }\end{array}$} & $\begin{array}{l}\text { Understand if there are } \\
\text { alternative perspectives on } \\
\text { the problem solution, which } \\
\text { could inform other types of } \\
\text { product innovation. }\end{array}$ & $\begin{array}{l}\text { Awareness of alternative tools } \\
\text { or solutions to access high } \\
\text { places at home }\end{array}$ & 7 \\
\hline & $\begin{array}{l}\text { Narrow focus on preferred } \\
\text { product innovation to inform } \\
\text { product development } \\
\text { priorities. }\end{array}$ & $\begin{array}{l}\text { An open question to elicit their } \\
\text { desired solution, followed by a } \\
\text { presentation of a range } \\
\text { product concepts (refer to } \\
\text { page } 22 \text { ) in order to further } \\
\text { narrow preferences. }\end{array}$ & 8,9 \\
\hline & $\begin{array}{l}\text { Evaluate opportunities of } \\
\text { developing sensor } \\
\text { technology as a way to } \\
\text { enhance tool safety, and } \\
\text { cater to potential unmet } \\
\text { consumer needs. }\end{array}$ & $\begin{array}{l}\text { Thoughts on desirability of } \\
\text { sensors to monitor health (as } \\
\text { a preventive tool) and/or to } \\
\text { detect and communicate falls } \\
\text { (as an emergency tool). }\end{array}$ & $\begin{array}{r}10 \\
11\end{array}$ \\
\hline
\end{tabular}




\begin{tabular}{|c|c|c|c|}
\hline $\begin{array}{l}\text { To validate/ } \\
\text { inform: }\end{array}$ & Question development & $\begin{array}{l}\text { Question type and } \\
\text { description }\end{array}$ & $\begin{array}{l}\text { Qn. } \\
\text { no. }\end{array}$ \\
\hline \multirow[t]{3}{*}{$\begin{array}{l}\text { Business } \\
\text { model } \\
\text { considerations }\end{array}$} & $\begin{array}{l}\text { Understand best channels to } \\
\text { disseminate information in } \\
\text { order to optimise product } \\
\text { awareness and exposure, } \\
\text { and ideal places to sell } \\
\text { product. }\end{array}$ & $\begin{array}{l}\text { Channels being used to } \\
\text { search for product information } \\
\text { and preferred way or place to } \\
\text { purchase product. }\end{array}$ & 12 \\
\hline & $\begin{array}{l}\text { Understand potential pitfalls } \\
\text { and good practices in } \\
\text { developing and marketing } \\
\text { products to older people. } \\
\text { This informs critical business } \\
\text { model strategies ranging } \\
\text { from development to } \\
\text { communication. }\end{array}$ & $\begin{array}{l}\text { Thoughts on the way products } \\
\text { for older people are being } \\
\text { designed and marketed. } \\
\text { Whether there are examples } \\
\text { of good products and factors } \\
\text { that could prevent purchase. }\end{array}$ & $13-15$ \\
\hline & $\begin{array}{l}\text { Further validate trend of } \\
\text { downsizing. Need to access } \\
\text { to high places at home could } \\
\text { grow due to lack of space, } \\
\text { thereby ensuring future need } \\
\text { and business sustainability. }\end{array}$ & $\begin{array}{l}\text { Thoughts on current home } \\
\text { size and intentions to move in } \\
\text { future. }\end{array}$ & 16 \\
\hline
\end{tabular}

Relatively similar questions were posed to family members, healthcare professionals, and government and voluntary organisations. Refer to respective appendices 2.1, 2.2 and $\mathbf{2 . 3}$ for full questionnaires.

\section{Stage 2: Semi structured interviews (approximately 20 minutes per interview)}

Participants recap (refer to Table 2.1): Seniors, Retirement Village managers, Engineers and Designers

A product sketch that was a consolidation of findings from Stage 1 was taken to another group of seniors, who were asked slightly different questions based on the themes that 
was gathered from the previous interviews. Refer to Chapter 3, page 57, Figure 3.4 for initial product sketch.

This was undertaken with the focus on refining initial ideas, to further test the concept and also served as an opportunity to further validate some of the previous assumptions, as a way to strengthen the initial research methodology. Table 2.5 and 2.6 summarises the questions in Stage 2.

Table 2.5 Summary of questionnaire development for seniors (refer to appendix 2.4)

\begin{tabular}{|c|c|c|c|}
\hline $\begin{array}{l}\text { To clarifyl } \\
\text { validate }\end{array}$ & Question development & $\begin{array}{l}\text { Question type and } \\
\text { description }\end{array}$ & $\begin{array}{l}\text { Qn. } \\
\text { no. }\end{array}$ \\
\hline \multirow[t]{2}{*}{$\begin{array}{l}\text { Product, } \\
\text { Market and } \\
\text { Business } \\
\text { model } \\
\text { opportunities }\end{array}$} & $\begin{array}{l}\text { Validate need of preferred tool } \\
\text { selected by seniors from Stage } \\
1 \text { to access high places at } \\
\text { home. This also further } \\
\text { validates the need of accessing } \\
\text { high places at home. }\end{array}$ & $\begin{array}{l}\text { Range of open ended } \\
\text { questions focusing on eliciting } \\
\text { details on what the tool is } \\
\text { being used for and the } \\
\text { purchase process behind it. }\end{array}$ & $\begin{array}{r}1 \text { to } \\
4\end{array}$ \\
\hline & $\begin{array}{l}\text { Explore if the need for product } \\
\text { changes over the course of } \\
\text { time and understand what } \\
\text { affects their decision to } \\
\text { continue or stop using the tool. } \\
\text { This validates/clarifies the need } \\
\text { to consider transitional phases } \\
\text { of ageing and its effects on } \\
\text { consumer behaviour. It further } \\
\text { informs potential safety features } \\
\text { to be included, at different } \\
\text { points in time. }\end{array}$ & $\begin{array}{l}\text { Rating scale question on } \\
\text { necessity of having tool at } \\
\text { home in three time periods of: } \\
\text { before, present and future. } \\
\text { Participants were also asked } \\
\text { to elaborate on their rating } \\
\text { reasons. }\end{array}$ & 5 \\
\hline
\end{tabular}




\begin{tabular}{|c|c|c|c|}
\hline $\begin{array}{l}\text { To clarifyl } \\
\text { validate }\end{array}$ & Question development & $\begin{array}{l}\text { Question type and } \\
\text { description }\end{array}$ & $\begin{array}{l}\text { Qn. } \\
\text { no. }\end{array}$ \\
\hline \multirow[t]{2}{*}{$\begin{array}{l}\text { Product } \\
\text { development }\end{array}$} & $\begin{array}{l}\text { Further clarify and validate } \\
\text { product attributes that are } \\
\text { important to consumers. }\end{array}$ & $\begin{array}{l}\text { Rating scale question on the } \\
\text { importance of a selection of } \\
\text { product attributes. A further } \\
\text { open ended question was } \\
\text { asked to find out if there are } \\
\text { other desired attributes not } \\
\text { within the list provided. }\end{array}$ & 6 \\
\hline & $\begin{array}{l}\text { Narrow down the monetary } \\
\text { value of additional product } \\
\text { attributes. This priorities the } \\
\text { type of product development to } \\
\text { focus on at the initial stages of } \\
\text { product launch. }\end{array}$ & $\begin{array}{l}\text { Open ended question on two } \\
\text { product attributes that } \\
\text { consumer is willing to pay } \\
\text { extra for. }\end{array}$ & 7 \\
\hline \multirow[t]{2}{*}{$\begin{array}{l}\text { Business } \\
\text { model } \\
\text { consideration } \\
\text { s }\end{array}$} & $\begin{array}{l}\text { Understand the purchase } \\
\text { behaviour of consumers in } \\
\text { order to formulate appropriate } \\
\text { business model strategies. }\end{array}$ & $\begin{array}{l}\text { Open ended question on } \\
\text { preferred way to purchase a } \\
\text { similar type of tool (e.g online } \\
\text { or in a store). }\end{array}$ & 8 \\
\hline & $\begin{array}{l}\text { Further understand the } \\
\text { potential of alternative } \\
\text { solutions. This helps to further } \\
\text { validate the need of the } \\
\text { preferred product option (from } \\
\text { Stage } 1 \text { findings) but also } \\
\text { identifies other product } \\
\text { opportunities for the future. }\end{array}$ & $\begin{array}{l}\text { Open ended questions on } \\
\text { opinions about drop-down } \\
\text { shelves, focusing on } \\
\text { desirability and comparison to } \\
\text { existing tool. }\end{array}$ & 9 \\
\hline
\end{tabular}


Table 2.6: Summary of questions for retirement village managers, designers and engineers

\begin{tabular}{|c|c|c|c|}
\hline $\begin{array}{l}\text { To validate/ } \\
\text { clarify: }\end{array}$ & Participants & Key summary of questions & Appendix \\
\hline $\begin{array}{l}\text { Market and } \\
\text { Business model } \\
\text { opportunities } \\
\text { (particularly as } \\
\text { an intermediary) }\end{array}$ & $\begin{array}{l}\text { Retirement } \\
\text { village } \\
\text { managers }\end{array}$ & $\begin{array}{l}\text { Perspectives on products } \\
\text { catered to older people and their } \\
\text { observations relating to } \\
\text { acceptance of assistive } \\
\text { technology. } \\
\text { Understanding the process to } \\
\text { establish a partnership with } \\
\text { retirement village as a potential } \\
\text { supplier of products to their } \\
\text { residents. }\end{array}$ & 2.5 \\
\hline $\begin{array}{l}\text { Product } \\
\text { development } \\
\text { possibilities and } \\
\text { business model } \\
\text { considerations }\end{array}$ & $\begin{array}{l}\text { Designer and } \\
\text { engineer }\end{array}$ & $\begin{array}{l}\text { - } \\
\text { pochnical and technological } \\
\text { product prototype. } \\
\text { Soliciting advice for product } \\
\text { improvements, intellectual } \\
\text { property (IP) protection and } \\
\text { regulatory requirements }\end{array}$ & 2.6 \\
\hline
\end{tabular}

\section{Stage 3: Online survey (approximately 5 minutes per survey)}

\section{Participants recap (refer to Table 2.1): Representation from all categories}

In this survey, a product prototype is presented. Refer to Chapter 3 for image of product prototype. Table 2.7 below summaries the type of questions in the survey and lays out the rationale behind them. Refer to Appendix 2.7 for the full set of questions. 
Table 2.7: Summary of online survey development and questions (Refer to appendix 2.7)

\begin{tabular}{|c|c|c|c|}
\hline $\begin{array}{l}\text { To validate/ } \\
\text { inform: }\end{array}$ & Question development & Question type and description & $\begin{array}{l}\text { Qn. } \\
\text { no. }\end{array}$ \\
\hline \multirow[t]{4}{*}{$\begin{array}{l}\text { Product } \\
\text { concept (is } \\
\text { it } \\
\text { desirable?) }\end{array}$} & $\begin{array}{l}\text { Test initial impressions and } \\
\text { visual attractiveness as a } \\
\text { gauge of potential willingness } \\
\text { to buy, thus leading to } \\
\text { commercial success. }\end{array}$ & $\begin{array}{l}\text { Likert scale questions (i.e level } \\
\text { of agreement with statement) } \\
\text { pertaining to perceived appeal, } \\
\text { safety, sturdiness and ease of } \\
\text { use of the product prototype. }\end{array}$ & $\begin{array}{r}1 \text { to } \\
4\end{array}$ \\
\hline & $\begin{array}{l}\text { Further clarify and validate } \\
\text { product attributes that } \\
\text { consumers are willing to pay } \\
\text { extra for. This priorities the } \\
\text { type of product development to } \\
\text { focus on at the initial stages of } \\
\text { product launch. }\end{array}$ & $\begin{array}{l}\text { Multiple-choice questions that } \\
\text { allows multiple answer selection } \\
\text { on product attributes one is } \\
\text { willing to pay extra for. }\end{array}$ & 6 \\
\hline & $\begin{array}{l}\text { Further validate and } \\
\text { understand the desirability of } \\
\text { sensor technology as part of } \\
\text { product innovation. It also } \\
\text { provides insights to product } \\
\text { development potential beyond } \\
\text { this context that could inform } \\
\text { future business model } \\
\text { opportunities. }\end{array}$ & $\begin{array}{l}\text { Multiple-choice questions on } \\
\text { preferred way sensor technology } \\
\text { is incorporated into product } \\
\text { prototype. }\end{array}$ & $\begin{array}{l}11, \\
12\end{array}$ \\
\hline & $\begin{array}{l}\text { Understand where the product } \\
\text { could improve to better meet } \\
\text { consumer expectations, and to } \\
\text { identify potential new areas of } \\
\text { product development such as } \\
\text { future product extensions. }\end{array}$ & $\begin{array}{l}\text { Open ended question that allows } \\
\text { respondents to include } \\
\text { suggestions to improve product } \\
\text { prototype. }\end{array}$ & 13 \\
\hline
\end{tabular}




\begin{tabular}{|c|c|c|c|}
\hline $\begin{array}{l}\text { To validate/ } \\
\text { inform: }\end{array}$ & Question development & Question type and description & $\begin{array}{l}\text { Qn. } \\
\text { no. }\end{array}$ \\
\hline \multirow[t]{2}{*}{$\begin{array}{l}\text { Market } \\
\text { positioning }\end{array}$} & $\begin{array}{l}\text { Understand whether product } \\
\text { prototype has competitive } \\
\text { advantage in the current } \\
\text { market. }\end{array}$ & $\begin{array}{l}\text { Likert scale questions (I.e } \\
\text { degree of positive/negative } \\
\text { emotion) pertaining to how } \\
\text { product prototype compares with } \\
\text { what is currently available in the } \\
\text { market. }\end{array}$ & 5 \\
\hline & $\begin{array}{l}\text { Understand whether product } \\
\text { prototype is a product worth } \\
\text { recommending, in order to } \\
\text { further validate its appeal and } \\
\text { competitive advantage. }\end{array}$ & $\begin{array}{l}\text { Likert scale questions (i.e } \\
\text { degree of likelihood) pertaining } \\
\text { to whether one would } \\
\text { recommend product prototype to } \\
\text { others. }\end{array}$ & 7 \\
\hline \multirow[t]{3}{*}{$\begin{array}{l}\text { Business } \\
\text { Model } \\
\text { strategy }\end{array}$} & $\begin{array}{l}\text { Understand the purchase } \\
\text { motivations of consumers in } \\
\text { order to tailor the marketing } \\
\text { message. }\end{array}$ & $\begin{array}{l}\text { Multiple-choice questions that } \\
\text { allows multiple answer selection } \\
\text { on whom the purchase of } \\
\text { product prototype would be for. }\end{array}$ & 10 \\
\hline & $\begin{array}{l}\text { Understand how important the } \\
\text { role of price plays in } \\
\text { consumers' purchase decision. } \\
\text { This informs the type of pricing } \\
\text { strategy, and thus production } \\
\text { considerations in the type of } \\
\text { business model formulation. }\end{array}$ & $\begin{array}{l}\text { Likert scale questions (i.e } \\
\text { degree of likelihood) pertaining } \\
\text { to purchase of product prototype } \\
\text { at two different price points of } \\
\$ 100 \text { and } \$ 150 \text {. }\end{array}$ & 8,9 \\
\hline & $\begin{array}{l}\text { Understand key decision } \\
\text { making factors in product } \\
\text { purchase in order to facilitate } \\
\text { sales, thus leading to } \\
\text { commercial success. }\end{array}$ & $\begin{array}{l}\text { Multiple-choice questions that } \\
\text { allows multiple answer selection } \\
\text { on key decision making factors } \\
\text { that would affect purchase. }\end{array}$ & 14 \\
\hline
\end{tabular}

\section{Stage 4: Consolidation of findings in Business Canvas Model}

Information was consolidated and analysed in order to formulate a business model (this is presented in the Discussion chapter). 


\subsection{Data Analysis}

Data was analysed through the method of coding and thematic analysis, and was done using a hybrid of deductive and inductive coding (Frereday, \& Muir-Cochrane 2006).

Deductive codes included themes from ageing, motivation and business theories, while inductive codes were recording based on emerging patterns. It was an iterative process of grouping and categorising data. At the final stage, key relevant information was put together in the Business Canvas Model as preparation for a business case.

Note-taking was conducted during semi structured interviews. Audio recording took place but full transcription was not conducted. Audio recordings were revisited to further pick up on themes that might have been missed out during note-taking. Table 2.8 provides a summary of how data was analysed.

Table 2.8: Summary of data analysis methods

\begin{tabular}{|c|c|c|}
\hline Stage & $\begin{array}{l}\text { Data collection } \\
\text { method } \\
\text { (recap) }\end{array}$ & Data Analysis description \\
\hline 1 & $\begin{array}{l}\text { Semi-structured } \\
\text { interviews } \\
\text { (open and } \\
\text { explorative } \\
\text { questions) }\end{array}$ & $\begin{array}{l}\text { Thematic coding and analysis was conducted with particular } \\
\text { emphasis on identifying emerging themes relating to } \\
\text { theories on motivation (Maslow's hierarchy of needs) and } \\
\text { successful ageing (Baltes' SOC) discussed in Chapter 1's } \\
\text { literature review. }\end{array}$ \\
\hline 2 & $\begin{array}{l}\text { Semi-structured } \\
\text { interviews } \\
\text { (mostly open } \\
\text { with some } \\
\text { Rating scale } \\
\text { questions in } \\
\text { interviews with } \\
\text { seniors) }\end{array}$ & $\begin{array}{l}\text { Thematic coding and analysis was similarly conducted. } \\
\text { Stage } 2 \text { analysis had a stronger focus on clarifying and } \\
\text { validating emerging patterns related to product/innovation. } \\
\text { Comparisons between Stage } 1 \text { and } 2 \text { findings were made to } \\
\text { identify discrepancies and similarities in order to further } \\
\text { validate Stage } 1 \text { findings and analysis. Tabulation of rating } \\
\text { scale responses was conducted. }\end{array}$ \\
\hline
\end{tabular}




\begin{tabular}{|c|c|c|}
\hline Stage & $\begin{array}{l}\text { Data collection } \\
\text { method } \\
\text { (recap) }\end{array}$ & Data Analysis description \\
\hline 3 & $\begin{array}{l}\text { Online survey } \\
\text { with mostly } \\
\text { closed } \\
\text { questions and } \\
\text { opportunity to } \\
\text { provide open- } \\
\text { ended answers }\end{array}$ & $\begin{array}{l}\text { Responses were tabulated in a spreadsheet and further } \\
\text { analysed for emerging patterns. Comparisons were made in } \\
\text { the information obtained from different participant } \\
\text { categories, as a way to observe potential patterns, and } \\
\text { again validate findings in previous Stages. Comments were } \\
\text { consolidated and summarised. }\end{array}$ \\
\hline 4 & $\begin{array}{l}\text { Business Model } \\
\text { Canvas (BMC) }\end{array}$ & $\begin{array}{l}\text { Information from Stage } 1 \text { to } 3 \text { of research was consolidated } \\
\text { and further analysed with an emphasis on business } \\
\text { frameworks such as Stakeholder Theory. Validation of } \\
\text { stakeholder assumptions further clarifies market, product } \\
\text { and business opportunities, thereby answering the project's } \\
\text { key research questions. Findings were then laid out within } \\
\text { BMC to identify critical factors for commercialisation } \\
\text { success. Information gaps were identified for further } \\
\text { secondary research and/or as implications for future } \\
\text { investigations. }\end{array}$ \\
\hline
\end{tabular}

\subsection{Reflections}

As this project was embarked at a very initial stage of idea development, i.e I did not set out to validate an exist product idea, it was a process of finding out what could be the potential innovation based on the need, then deciding on the strategy. Although I had a general plan of how the research design needed to take place, these were not set in stone and I tried to ensure there was enough flexibility from the initial plan to accommodate deviations from the original plan. The research methodology evolved progressively at various points of the data collection process but this was also reflective of the flexible approach I undertook from the start.

Some evolvements: 
- I experienced difficulties in getting the target number of family representatives (initially aimed for 6 but ended up with 4) but had more seniors than expected (initially aimed for 18 but ended up with 23). Thus, I made a choice to focus efforts on interviewing seniors. As a result, I took the opportunity to develop a new set of questions i.e second version of semi-structured interviews to further test/validate initial assumptions.

However, even if tools or techniques evolved, I would say the direction of the methodology remained relatively constant as the research focus and vision remained clear.

\subsection{Limitations}

\section{Sample size and selection bias}

I acknowledge that this research consists of a limited sample size. Selection bias could have occurred as sampling was non-random. A larger group of participants must be involved in further studies to obtain stronger quantifiable validations before financial investments. More product developmental work must be done, such as creating a functioning product prototype to be tested by participants.

\section{Scope}

Due to time and resource constraints, this research was limited to Wellington, New Zealand. This might suggest that the findings could thus only be representative of this location. However, being a developed and cosmopolitan city, Wellington offers similarities to other urban environments with an ageing population, such as Singapore. Thus, it would be fair to make assumptions that certain findings from this research could be translatable to other places.

The above-mentioned limitations were, however, taken into consideration during the research design process. For the scope of this thesis, I am confident that my methodology, which sought to validate and re-validate findings at each stage of the research, has resulted in findings that could be representative of a wider population segment. Therefore, I am confident that these limitations do not undermine the validity and value of this research. 


\subsection{Summary}

In summary, I have provided the rationale for my predominantly qualitative research methodology, and laid out the specific assumptions that were explored as part of this project. The following chapter describes the findings gathered and analysed using the methodology described in this chapter. 


\section{CHAPTER 3: FINDINGS \& ANALYSIS}

\subsection{Overview}

This chapter presents the findings and analysis of the data gathered from the research outlined in the methodology section. As a recap, my research began with:

1) Understanding the need of accessing high places at home among older people, in order to develop safer product innovation(s) based on consumer needs and preferences.

2) Following on, it aimed to investigate whether the innovation(s) could be realistically developed and commercialised (validated through the support of stakeholders), in the context of the New Zealand market.

My research was underpinned by several assumptions. As mentioned in the Methodology chapter, specific to my research topic, I synthesised relevant "successful ageing" theories, consumer behaviour concepts and business frameworks to formulate research questions, which also served as the basis of how I analysed the gathered information in a thematic manner. Sections 3.2 to 3.11 predominantly addresses research question 1 while Sections 3.12 and 3.13 addresses research question 2. Figure 3.1 provides an overview of seniors interviewed, broken down into categories. 
Figure 3.1: Overview of seniors (Total 23 interviewed)

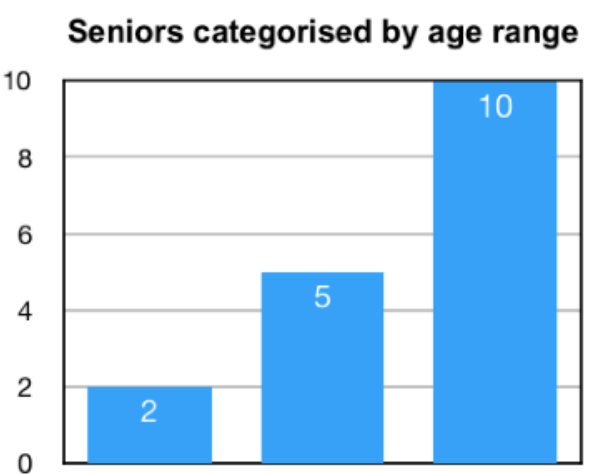

60 to 69

80 to 90

Seniors categorised by gender

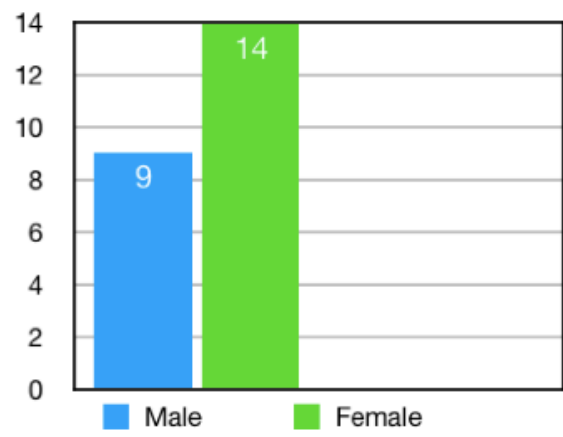

Seniors categorised by dwellings

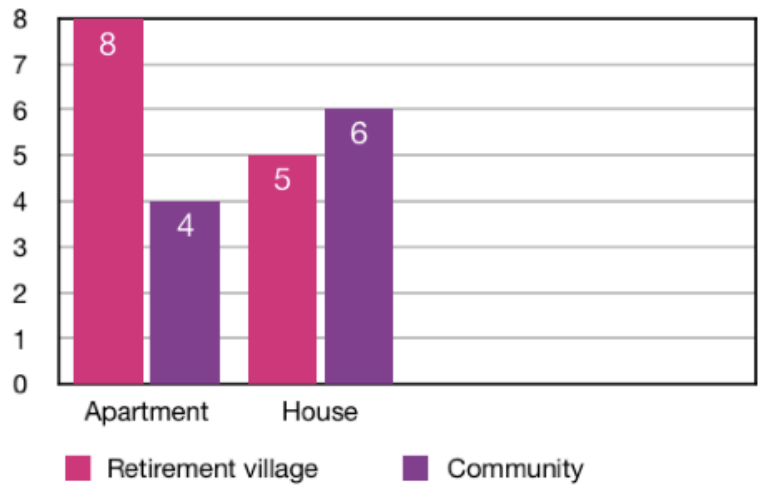

Seniors categorised by living arrangement

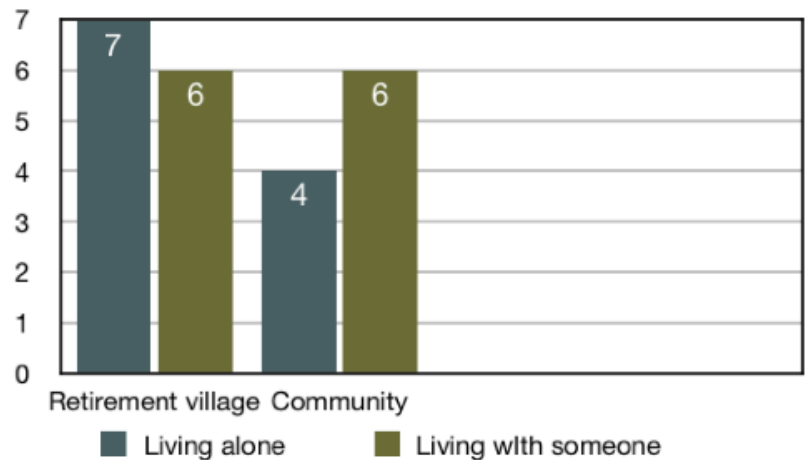

\subsection{Needs Recognition}

Table 3.1 below presents a summary of seniors' needs in relation to accessing high places at home.

Table 3.1 Summary of tasks requiring access to high places

\begin{tabular}{|l|l|l|}
\hline $\begin{array}{l}\text { Most common } \\
\begin{array}{l}\text { Storage (getting things down } \\
\text { and/or putting things up) }\end{array}\end{array}$ & Fairly common & Unique examples \\
\hline $\begin{array}{l}\text { Repair, cleaning and tidying } \\
\text { activities }\end{array}$ & Painting & Adjusting cuckoo clock \\
\hline & Gardening (e.g plant pruning) & \\
\hline & Smoke alarms & Projector set up \\
\hline
\end{tabular}




\section{Seniors' needs}

Most common: Referring to Table 3.1, one of the most common tasks that require access to high spaces is retrieving and storing things in high shelves and cabinets. A variety of examples including food, linen, books and documents were cited as items that regularly needed to be placed up and taken down. It was also very common to engage in general home maintenance tasks such as repair, cleaning and tidying activities.

Fairly common: The need to change lightbulbs was a fairly common example. Painting was often cited as something seniors enjoyed and wanted to do as long as possible. Those who live in a house with garden commonly engaged in gardening activities such as pruning tall plants. There were several instances of seniors who live in the community who cited needing to check and change smoke alarm batteries. Those living in retirement villages indicated they did not have this need as this task is being managed by on-site tradesmen.

Unique examples: There were examples of unique cases such as a specific need by a 90 year old senior (male) who lives alone in a retirement village apartment, to step on a stool to adjust a cuckoo clock, and another senior's (80 year old male, lives alone in a retirement village apartment) ad-hoc need to stand on a chair to set up a projector screen for an event at the retirement village.

\section{Other stakeholders' examples}

The existence or awareness of need is also further supported by other stakeholders who cite instances of seniors engaging in activities that require access to high spaces at home.

\section{Family member}

One of the daughters knows that her parents require access to high spaces at home in order to change the heat pump filter. A son is aware that his dad needs to get things down from high storage, and does all the lightbulb changing at home.

\section{Organisation representative}

One of the government representatives revealed how her grandmother, in her $80 \mathrm{~s}$, was still climbing onto a ladder to clean cobwebs at home. She further shared that her grandmother insisted on doing things herself as it was her pride. 
One of the engineers mentioned that his father-in-law, who is in his late 70 s, is still climbing ladders to paint the house, to which he indicates "is risky" but concedes that he has to respect his father-in-law's needs with the quote:

- "But how do you stop him, what can you do about it...except try to make it safer?"

\section{Health care professional}

One of the occupational therapists gave an example of a house visit where a senior climbed onto the table in order to access a plate kept in a high storage, as she wanted to show the item to her. She was not able to stop the older person as she was too quick and insistent.

Other healthcare professionals mentioned that cases where seniors suffer injuries from attempting to access high spaces at home are relatively common. This further substantiates the need to access high place among older people. At the same time, common incidences of injuries could suggest that current tools might be inadequate to ensure the safety of older adults.

Analysis: There are a variety of needs. A commonality observed was needs arising due to lifestyle and enjoyment of task. Although some of the stakeholders were interviewed, it was quite common for them to cite examples of seniors they were related to. This suggests that this need is in fact well observed in the community. The need by older people suggests deeper motivations, which will be further analysed in section 3.3.

\subsubsection{Unmet needs (frustration)}

Some of the seniors interviewed are unable to access high places at home due to physical limitations, such as hip, spinal, knee and shoulder problems. One senior (female, 85 , lives alone in a retirement village apartment) cited being "too short" to be able to access high places and expressed some unhappiness about the height of cupboards in the apartment she lives in (within a retirement village). She ended up customising her own cabinet because she "can't use" any of the kitchen storage. It appears that most of the seniors who are unable to access high places at home have unmet needs. When asked about the subject, most communicated a certain degree of resignation or frustration to their circumstances, with quotes presented in Table 3.2. 
Table 3.2: Quotes from seniors which reflect frustrations

\begin{tabular}{|c|c|c|c|}
\hline Seniors & Quote & & Emerging themes \\
\hline A & - & $\begin{array}{l}\text { "I can't reach high spaces. I have a home } \\
\text { help from ACCESS...but I don't like to get } \\
\text { (her) to do things for me." }\end{array}$ & Independence \\
\hline B & - & $\begin{array}{l}\text { "I can't do it anymore...my wife does it... } \\
\text { but I would like to be able to help out } \\
\text { more...because its important to feel } \\
\text { useful." }\end{array}$ & $\begin{array}{l}\text { - } \quad \text { Not wanting to } \\
\text { be a burden }\end{array}$ \\
\hline C & - & $\begin{array}{l}\text { "I can't...so I don't do it...I'm a very } \\
\text { cautious person... and it is dangerous for } \\
\text { me to try to get up there. I am aware if I } \\
\text { fall, I will cost the government so I am very } \\
\text { careful. Look at all my clothes...I just } \\
\text { leave them there. I don't care!" }\end{array}$ & $\begin{array}{l}\text { - } \\
\text { Independence } \\
\text { Dot wanting to } \\
\text { be a burden } \\
\text { Defence } \\
\text { mechanism }\end{array}$ \\
\hline
\end{tabular}

As an elaboration of the above point, when Senior A (who cannot access high spaces due to knee problems) was showed an example of a proposed improved step ladder with safety handles (refer page 9 , Figure 1.1, image 1), she immediately responded with:

- $\quad$ "Yes, I want a ladder like that! Those handles are very good, give me a ladder like that and I can do things myself! Is this available?"

Analysis: In this example, Senior A was instantly attracted to the idea of a safer step ladder, which will enable her to regain the independence that she had lost. Her obvious interest for the product and enquiry about its availability shows her strong desire for independence "to do things [herself]" also supports the assumption that there is a need for a safer tool to access high places at home by older people.

It is my interpretation that the inability to participate in the access of high places at home does not necessary indicate an absence of need. Instead, it is an acceptance that the need has been eclipsed by the presence of risks. Themes of desiring personal 
independence, not wanting to be a burden (social independence) and defence mechanism (defending one's inability to achieve the task as means of comfort) have been observed here.

\subsubsection{Covert needs (unawareness until prompted)}

In my interviews, there were a few cases of seniors who would start the interview claiming they have no need to access high places at home. However, as the interview progressed, they would reveal instances of having to use a tool to access high places.

For example, the 90 year old senior claimed that he had no need to access high places at home, yet as the interview progressed, he revealed he went through extensive research to purchase a "sturdy step stool" so that he could continue to adjust his cuckoo clock each month. This unawareness was also observed in Senior C (Table 3.2) who initially mentioned that she does not get up to any high places because it is "dangerous" and that she is "very careful". However, she later revealed that she would stand on two phone books if she needed to reach a high place to hang her clothes.

Analysis: This shows that apart from recognised needs, there are some needs which are unconscious. It is important to uncover covert needs and address unmet needs. Covert needs could result in potential safety hazards, hence, it is crucial to facilitate better self-awareness among older people about their actions at home. It would be advisable for them to adopt safer tools instead of engaging in unsafe behaviour without realising it.

\subsubsection{Future needs}

As an extension of the trend of downsizing mentioned in Chapter 1, there was further validation of this from the research findings. Table 3.3 presents a summary of senior's intention to move in the future. 
Table 3.3: Seniors' intention to move in the future

\begin{tabular}{|l|l|r|l|l|}
\hline $\begin{array}{l}\text { Current } \\
\text { dwelling }\end{array}$ & Type & $\begin{array}{l}\text { Number of } \\
\text { participants }\end{array}$ & $\begin{array}{l}\text { Plan to } \\
\text { move? }\end{array}$ & Where to? \\
\hline $\begin{array}{l}\text { Retirement } \\
\text { village }\end{array}$ & Apartment & 8 & Mostly no & N/A \\
\hline & House & 5 & Mostly yes & Apartment \\
\hline Community & Apartment & 4 & Mostly no & N/A \\
\hline & House & 6 & Mostly yes & Apartment \\
\hline
\end{tabular}

Most seniors interviewed either have downsized or have the intention to downsize. One of the seniors interviewed revealed that his motivation to purchase a step ladders that comes with a top hand rail was due to him having downsized from larger home to an apartment in a retirement village. Due to the limited space in his new abode, he wanted to optimise whatever high spaces he had at home. Hence, he bought high shelves, resulting in a need to buy a step ladder in order to access his storage space. This is a validation of my assumption in the Introduction. One of the retirement village managers also indicated that there are plans to build more apartment units due to limited land space, as well as increasing demand for smaller homes by older people.

Analysis: There is opportunity for future growth due to potential increased need of accessing high places at home.

\subsection{Importance of need}

For the seniors who are still able to access high spaces, this need was in general, relatively important for most interviewed, with some more so than others. A large number of responses indicated "very important" or "quite important" in comparison to seeking assistance. Several mentioned it was "fairly important" and a couple said "not that important" but would follow up with details which might imply a higher level of importance than what it is outwardly conveyed. Table 3.3 on page 52 presents some quotes arranged by level of importance, with the last column identifying emerging themes that will be discussed in the next section. 
Table 3.4: Quotes from seniors relating to importance of need

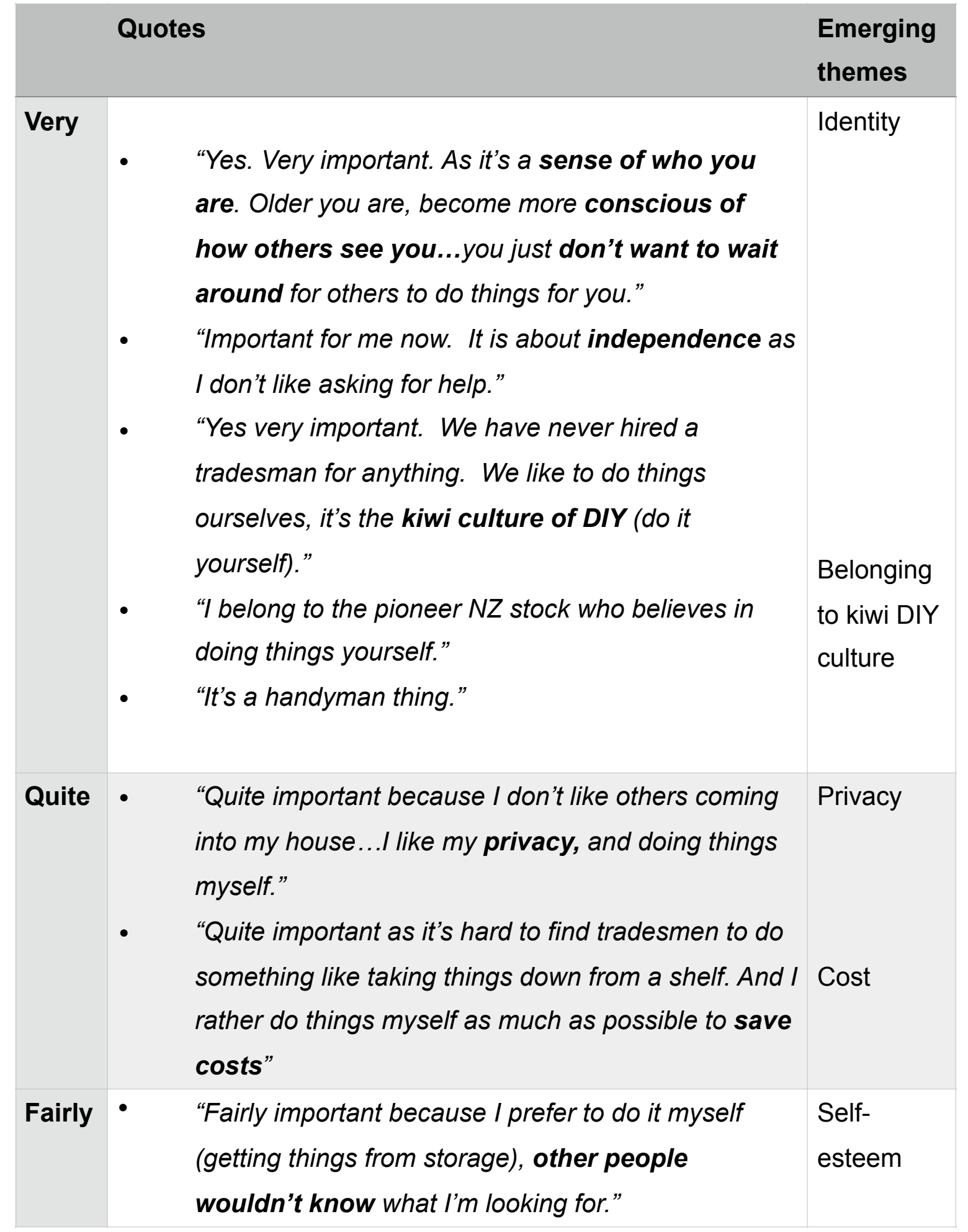




\begin{tabular}{|c|c|c|c|}
\hline \multicolumn{3}{|c|}{ Quotes } & $\begin{array}{l}\text { Emerging } \\
\text { themes }\end{array}$ \\
\hline $\begin{array}{l}\text { Not } \\
\text { that }\end{array}$ & $\bullet$ & $\begin{array}{l}\text { "Not that important...but I would want to save costs } \\
\text { and try to do things myself as much as possible } \\
\text { instead of getting a tradesman or painter. I am living } \\
\text { on pension and need to save money." } \\
\text { "Not that important...I guess it's something I am } \\
\text { willing to give up, and I have rearranged my } \\
\text { house in the last few years so that there is less } \\
\text { need to go high up. I've also invested in long- } \\
\text { saving bulbs. Just the occasional tasks...but if } \\
\text { the bulb needs changing, I would prefer to do it } \\
\text { myself". }\end{array}$ & $\begin{array}{l}\text { Cost, } \\
\text { elimination } \\
\text { of needs } \\
\text { but doesn't } \\
\text { mean no } \\
\text { need } \\
\text { (SOC) }\end{array}$ \\
\hline
\end{tabular}

\subsection{Motivation}

\subsubsection{Seniors: Independence as part of successful ageing}

Identify (self and social): The first quote in the "Very important" category illustrates the theme of independence that reflects the three dimensions of personal, social and emotional independence. This was earlier mentioned in Chapter 1, page 10. The quote suggests that personal identity, a "sense of who you are" is interconnected to the social aspect of "how others see you" and not wanting to "wait around for others", all of which contributes to the emotional wellbeing of how successful an older person feels about his or her ageing process. Therefore, independence has to be taken in a wider context of an individual's relationship and interaction with society. This suggests implications in the positioning and marketing communication of a new product in the market.

Belonging to Kiwi DIY Culture: The 2nd to 4th quotes in the "Very important" category further highlights the idea of independence as part of the wider "Kiwi Culture" of "do it yourself". This is especially prevalent in older adults who view themselves as "pioneer stock" and take immense pride in being able to manage 
home tasks independently, instead of relying on other people. This is also substantiated by one of the occupational therapists who suggested seniors often want to identify with the "kiwi bloke DIY culture" as a factor contributing to the need of accessing high places at home. Therefore, achieving independence implies being part of New Zealand culture and is meaningful and important because it provides older people with a strong sense of identity.

Hypothetical personality construction (that could be relevant to profiling the target consumer segment): I am a true New Zealander because I can do thing myself, I am independent, I am not afraid of ageing because I can still do that things I want to do. I am ageing successfully.

Privacy (protection of personal space is also a form of safety): One of the seniors stated "privacy" as a reason for preferring to do things herself. From this statement, I infer that privacy is related to a protection of personal space and is a way to safeguard personal safety. The reliance on others for assistance requires inviting (potentially) a stranger (e.g tradesman) into one's private space. This could be unnerving for some people, perhaps particularly for older women. Hence, one should not assume that availability of services would eliminated the desire for older people to do things themselves.

Saving costs (Preserving financial safety for independence): The theme of saving costs was also commonly observed. Several seniors noted that because they are only living on a pension, they need to be careful with money. I infer that the desire to save costs is linked to financial safety, which contributes to financial independence (i.e not having to rely on social benefits), where again the theme of independence within a social context of not being a burden to others comes out strong.

\section{Selection, Optimisation, Compensation (SOC) (Adjusting needs with course}

of ageing): The display of SOC can be inferred from the last quote in Table 3.3. For this senior, he made a choice to give up his need to access high places (narrow his selection of needs). The actions of rearranging items and investing in long-life bulbs suggests both evidence of optimisation and compensation. However, the 
critical point in his comment was where he stated he would prefer to do it himself when the long-life bulbs requires changing. This implies that the need to access high places independently is still evident.

Further example of the application of SOC to preserve independence for as long as possible is presented in Table 3.5 .

Table 3.5: Application of SOC

\begin{tabular}{|c|c|c|c|}
\hline $\begin{array}{l}\text { Profile of } \\
\text { senior }\end{array}$ & Selection & Optimisation & Compensation \\
\hline $\begin{array}{l}90 \text { year } \\
\text { old man } \\
\text { living in } \\
\text { retirement } \\
\text { village } \\
\text { apartment }\end{array}$ & $\begin{array}{l}\text { Cites the need to stand on } \\
\text { a step stool to adjust his } \\
\text { cuckoo clock on a monthly } \\
\text { basis. Further revealed } \\
\text { that in his } 80 \text { s which he } \\
\text { considers his "younger } \\
\text { day", he used to stand on } \\
\text { ladders to paint his house. } \\
\text { He has given that up now } \\
\text { because he understands } \\
\text { the risks involved. As can } \\
\text { be seen, with age and } \\
\text { acknowledge of physical } \\
\text { declines, he has adopted } \\
\text { the method of selection } \\
\text { (narrowing his needs) to } \\
\text { minimise losses and } \\
\text { maximise gains. }\end{array}$ & $\begin{array}{l}\text { Conducted a } \\
\text { relatively extensive } \\
\text { search for a sturdy } \\
\text { step stool. He } \\
\text { evaluated several } \\
\text { options by } \\
\text { physically going to } \\
\text { a few hardware } \\
\text { stores to shop for } \\
\text { his desired tool. } \\
\text { The step stool is } \\
\text { his means to } \\
\text { optimise his ability } \\
\text { to achieve the } \\
\text { independence he } \\
\text { desires. }\end{array}$ & $\begin{array}{l}\text { Acknowledges } \\
\text { that there will a } \\
\text { day when it would } \\
\text { be safer to ask for } \\
\text { help (i.e } \\
\text { retirement village } \\
\text { staff). But } \\
\text { believes what he } \\
\text { is currently doing } \\
\text { is within his ability } \\
\text { so thus, prefers } \\
\text { not seeking help } \\
\text { yet. }\end{array}$ \\
\hline
\end{tabular}

The application of SOC can be further analysed in the context of Maslow's hierarchy of needs. Refer to Table 3.6 on the next page. Findings suggests that the continuous process of going through each step of SOC could be related to highest level of need i.e self-actualisation. For example, a 80 year old man who also lives in a retirement village, expressed resolute desire for changing the lightbulbs in his home every month. He 
perceives this task as a "challenge" for him to overcome, and that each time he is able to successfully complete the activity, he feels good about himself. It can inferred that the achievement of household tasks is perhaps a reflection of one's ability to reach their (agespecific) potential, and an indication of successful ageing.

Table 3.6: Application of Maslow's hierarchy of needs: Access to high places as a higher level need

\begin{tabular}{|c|c|}
\hline $\begin{array}{l}\text { Maslow's hierarchy } \\
\text { of needs }\end{array}$ & Quotes \\
\hline $\begin{array}{l}\text { - Self- } \\
\text { actualisation }\end{array}$ & $\begin{array}{l}\text { - "I treat it like a challenge...to } \\
\text { overcome" }\end{array}$ \\
\hline Esteem & "prefer to do it myself" \\
\hline - $\quad$ Social & $\begin{array}{l}\text { - " "it's a handyman thing" } \\
\text { - } \quad \text { "Kiwi DIY culture" }\end{array}$ \\
\hline - $\quad$ Safety & "those handles will keep me safe" \\
\hline
\end{tabular}

\subsubsection{Other stakeholders: Importance of safety for successful ageing}

Findings reveal that other stakeholders (e.g family members, healthcare professionals, government and voluntary organisation representatives) placed a greater emphasis on safety, perceiving the safeguard of older people's physical safety as crucial for successful ageing. For example, their comments on seniors' need to access high places at home often conveyed disapproval and veered towards task avoidance. Some quotes as follows:

- "Older people really shouldn't be climbing (on ladders)"

- " "I would rather they just take things down."

Analysis: As an elaboration of Maslow's theory, other stakeholders appear to view the need to access high places mainly as a lower level need of safety. Therefore, in their perspectives, they are more concerned about the risks and harm that could occur. The problem with others' perception of ageing is that, we tend to remove the emotional attachments that people form with activities and tasks and often only see things from a 
"risk and safety" perspective. There is a failure to realise that beyond physical risks, there are emotional and mental risks. The feeling of inadequacy, uselessness and accumulative feelings of dependence (being a burden) may be more detrimental than physical injuries.

Application to commercialisation: It is important to recognise that older people want to continue with their life patterns. Hence, product innovation should emphasise making familiar tools better and safer for older people, instead of being overly revolutionary and attempting to eliminate need. The danger in radical innovation is consumer resistance, which would impede successful commercialisation.

\subsubsection{Common motivation among stakeholders: Successful Ageing}

Although the perspectives on the importance of the need to access high places at home differs between seniors and other stakeholders, it is evident that all participants agree that Successful Ageing is important. However, the way to achieve Successful Ageing is perceived differently. Again, the application of SOC is evident. Seniors prefer to transit gradually along a continuous process of SOC, while other stakeholders seem to view the Compensation stage as the most desirable way to achieve Successful Ageing, as it is the least risky, in their opinion.

Application to product commercialisation: This implies that product should take into consideration the transitionary aspects of ageing, such as an "adaptive" design. Hence, a modular concept is advisable. 


\subsection{Current tools used}

Table 3.7 provides an overview of current tools used by seniors to access high places at home.

Table 3.7: Current tools used

\begin{tabular}{|l|l|l|}
\hline Most common & Fairly common & Unique cases \\
\hline Step ladder & Step stool & Stacking phone books \\
\hline & Tradesman ladder & \\
\hline
\end{tabular}

Figure 3.2 and 3.3 shows photographs of tools used (taken during interviews at seniors' homes):

Figure 3.2: Examples of step ladders currently used by seniors at home
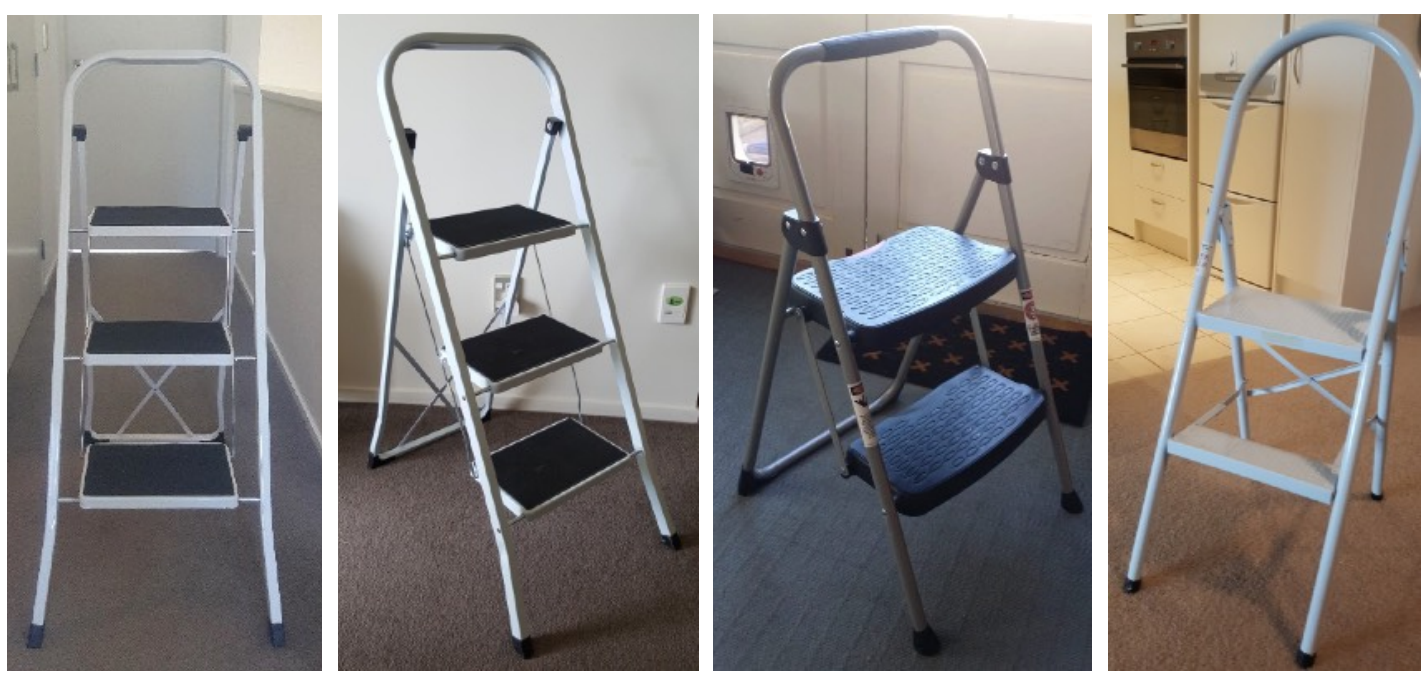
Figure 3.3: Examples of step stools currently used by seniors at home
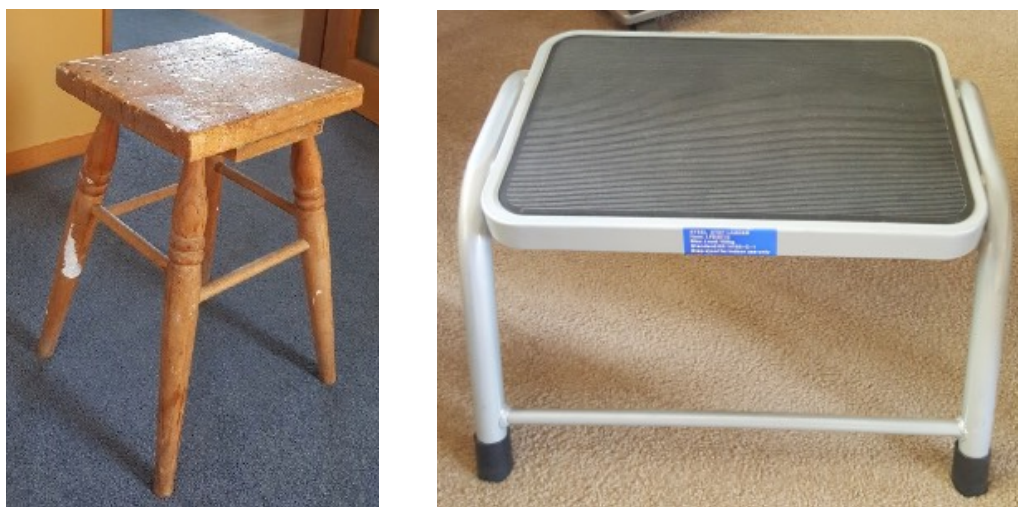

The most common tool used by seniors at home to access high place is a step ladder. There were also a few who cited using step stools. It was also quite common to have more than one type of tool to access high places i.e one step stool or step ladder for most tasks, but also a taller tradesman ladder for occasional activities such as painting or cleaning the roof.

Analysis: In their own way, older people are using whatever is available in their own homes as assistive technology, even if they do not realise it. The issue is that some "assistive technology" brings safety hazards. It appears that most also do realise there is risk involved, but perhaps lack of choice and information have served as a barrier to adopt safer practices and tools. These are important implications for marketing communication strategies, especially in creating greater awareness of assistive technology for older people.

\subsection{Current and anticipated challenges}

A majority of seniors who are still currently able to access high spaces with their existing tool, indicated that, with age, they anticipate that it would get more difficult to use the tool due to an expectation in a decline of their physical health. This is based on the assumption that there are no safer tools available.

The issues of balance and stability was common, with most believing that their health may deteriorate in the future. Several indicated they have had at least one of knee, hip or shoulder replacements. Common health conditions include: osteoarthritis, back problems, 
spinal issues, sore knees, shoulder problems, weak arms, painful joints, stiff muscles, and decline in vision.

Family members indicated that they think it is unsafe, either now or into the future, for their senior family members to be using the current step ladder. Healthcare professionals, in particular occupational therapists, think the current tool is risky. Government and voluntary organisation representations adopt a mentality of "it is risky" while acknowledging that older people tend to take such risks in order to showcase their independence. There is a general sentiment that more should be done to safeguard safety (in accessing high places), although no absolute consensus exists among stakeholders on how to achieve this.

Analysis and application to commercialisation: More safety features are needed in tools used for accessing high places. For example, features that provide additional stability support and perhaps feedback to aid in injury prevention. Input from other stakeholders should be included in the product development in order to gain their support in recommending tool to seniors. 


\subsection{Alternatives}

Table 3.8: Alternative solutions

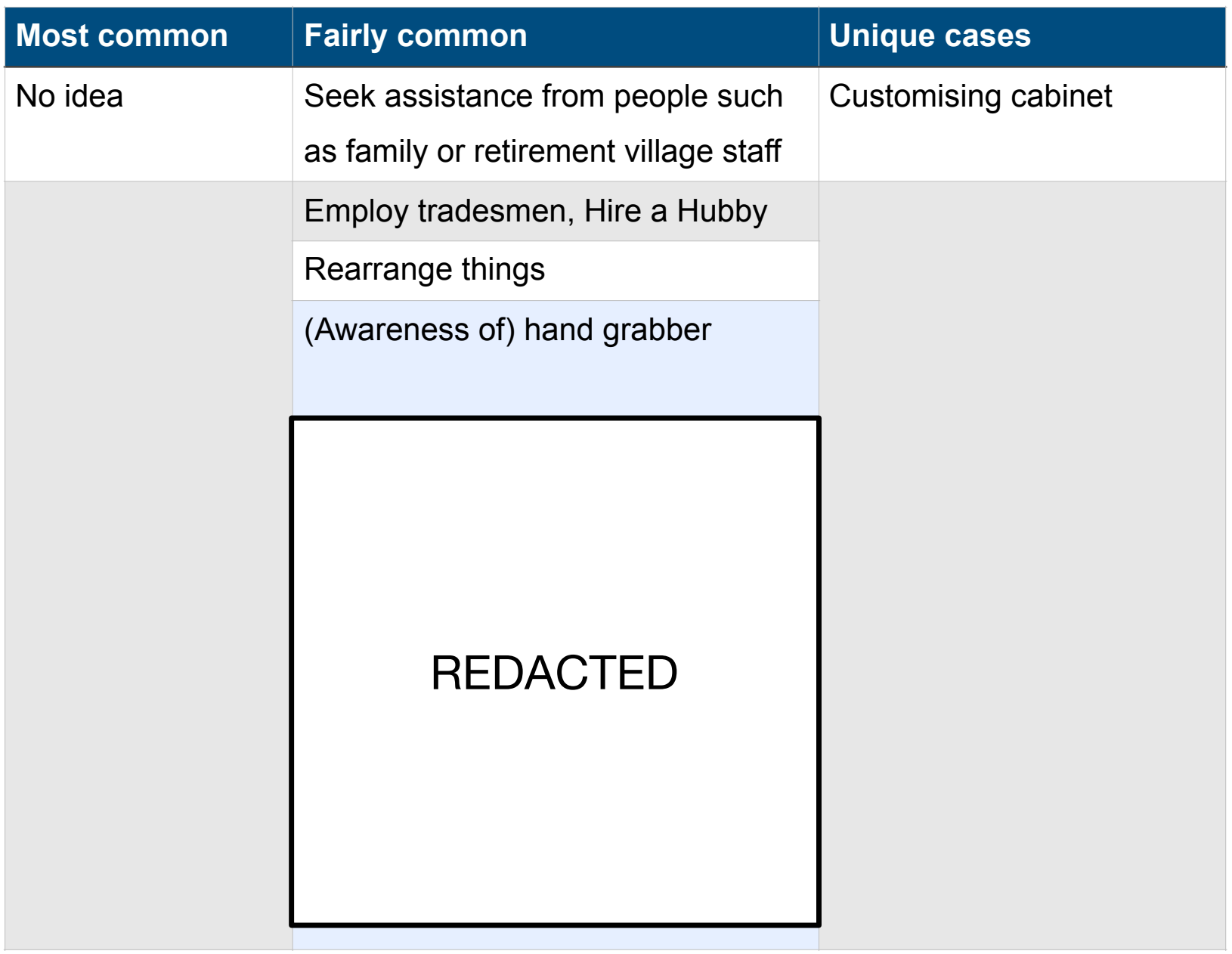

Most of the participants were not aware of alternatives and the most common response was "no idea". A few said they would employ tradesmen or call upon others such as grandchildren or children to help. Seniors living in a retirement village tend to call on onsite maintenance staff for help. Those living in the community appear to try to rely on themselves more often. However, even those in retirement villages indicated that they try to do most things independently. Some indicated they are aware of hand-grabbers as a possibility. One of the seniors has a hand-grabber at home. However, most would follow up with a comment that it is not good for heavy things and is more suited to pick things up from the ground and suggested to improve this tool.

Some mentioned that they have started to rearrange the house to keep things at a lower level to reduce the need to get up to high spaces. 
In general, the alternatives cited are usually compensatory methods of Selection, Optimisation and Compensation (refer page 10). Elements of unhappiness or frustrations were usually present when seniors talked about adopting methods of compensation. For example, the quote below illustrations this point:

* "I guess we could [hire a tradesman]... but you know we have never done that in our lives, and we just don't like to do that, but I guess if it comes to that point, we have to...[sigh]". -Couple (85 year old male and 80 year old female, living in a house in the community)

Analysis and application to commercialisation: This is further evidence that seniors often view compensatory methods as a reluctant last resort, which marks a point in time when they have no choice but to give up their independence. Again, this highlights the market and product opportunity to develop tools to enable and preserve independence for older people. It could also be worthwhile to explore the hand grabber to see if it is possible to improve on it as ideas for further product development and product extensions.

\subsection{Desired innovation/solution}

\section{Stage 1 Findings}

In the first stage of the research, participants were asked to select their preferred product concept based on the options (refer to page 9), as well as willingness to include sensor technology. Table 3.9 provides a summary of on the type of innovation or solution stakeholders prefer, while table 3.10 summarises stakeholder's views on sensor technology. 
Table 3.9: Summary of preferred on product concept/solution

\begin{tabular}{|c|c|c|c|c|}
\hline & Seniors & Family & $\begin{array}{l}\text { Healthcare } \\
\text { professionals }\end{array}$ & $\begin{array}{l}\text { Voluntary/ } \\
\text { Government }\end{array}$ \\
\hline Preference & $\begin{array}{l}\text { Mostly step ladder. } \\
\text { Minimal interest in bike, } \\
\text { lift and robotic suit. } \\
\text { *The drop-down } \\
\text { shelves garnered some } \\
\text { positive feedback } \\
\text { although most said they } \\
\text { would only use it if their } \\
\text { home came with it. It } \\
\text { would be a lot of work } \\
\text { retrofitting their existing } \\
\text { storage. }\end{array}$ & $\begin{array}{l}\text { Bike, lift or } \\
\text { combination } \\
\text { or avoid task. }\end{array}$ & $\begin{array}{l}\text { Physiotherapis } \\
\text { t and nurse: } \\
\text { Step ladder } \\
\text { Occupational } \\
\text { therapist: Lift } \\
\text { or moveable } \\
\text { spaces (in } \\
\text { future) or avoid } \\
\text { task. }\end{array}$ & $\begin{array}{l}\text { Lift or a } \\
\text { combination } \\
\text { of bike and lift. }\end{array}$ \\
\hline
\end{tabular}

The findings revealed that their preferred innovation was a tool that is as similar to the current tool as possible, hence, their preferred choice of innovation is an improved step ladder. Majority of seniors expressed desire for a safer step ladder that had handles, nonslip material, had a sturdier base, foldable (as storage is an issue), and lightweight so that it could be moved around easily.

Most seniors expressed that they find electronic (automated devices) complicated to operate. However, a majority of other stakeholders (family members, occupational therapists, voluntary and government organisations) preferred a solution that veered towards some form of automation, with the assumption that the need for lesser physical exertion (i.e climbing steps) equates to lesser risks. 
Table 3.10: Summary of views of sensor technology

\begin{tabular}{|l|l|l|l|l|}
\hline & Seniors & Family & $\begin{array}{l}\text { Healthcare } \\
\text { professionals }\end{array}$ & $\begin{array}{l}\text { NGOs and } \\
\text { Government }\end{array}$ \\
\hline $\begin{array}{l}\text { Sensor function } \\
\text { Health monitoring }\end{array}$ & Not supportive & $\begin{array}{l}\text { Mostly } \\
\text { supportive }\end{array}$ & $\begin{array}{l}\text { Some are } \\
\text { supportive }\end{array}$ & $\begin{array}{l}\text { Some are } \\
\text { supportive }\end{array}$ \\
\hline Fall detection & $\begin{array}{l}\text { Mostly } \\
\text { supportive }\end{array}$ & $\begin{array}{l}\text { Mostly } \\
\text { supportive }\end{array}$ & $\begin{array}{l}\text { Mostly } \\
\text { supportive }\end{array}$ & $\begin{array}{l}\text { Mostly } \\
\text { supportive }\end{array}$ \\
\hline
\end{tabular}

Most seniors welcomed idea of sensors embedded in the step ladder to detect falls, but were resistant to sensors to monitor state of health. There were a small minority who expressed support for the monitoring function, indicating it is good to know what is happening to their body so they can take preventive measures. They tend to be the "young old" i.e in their 60s. However, the oldest participant at 90 year old also said, "sensors are the way of the future".

The monitoring function is also popular with the physiotherapist, some family members, and government and voluntary representatives. It is not supported by occupational therapists as they indicated that their role is focused on getting a task done in the "most efficient and economical way...there and then" instead of reviewing and monitoring patient information.

\section{Analysis of differences in motivations and applications to commercialisation:}

Seniors appeared to desire an incrementally improved tool with potential for radical functions operated in the most familiar way as possible, while other stakeholders seemed to be more supportive of radical innovation that is meant to revolutionise the way a task is achieved but requires an unfamiliar way of operation.

This contrasted with the view of seniors who expressed their fear of electronic products due to concerns of the product malfunctioning and/or not knowing how to operate it correctly. This discrepancy between what others perceive as good for seniors and the opinions of seniors offers room for further exploration, and suggests more education and awareness needs to be done. 
It also appears that the focus for product development does not need to focus on sensors to monitor health (at least for now). However, the potential interest in fall detection sensors suggest this could be a desirable product attribute. It would be worthwhile to pursue its development.

As the target consumers are older people, the decision to focus on the desires of older consumers was made. With a higher than expected number of interested participants among older people in a retirement village, I decided to further validate the need of an improved step ladder in the next stage of the research.

\section{Stage 2 Findings: confirmation of step ladder as preferred solution}

With a very clear indication that the step ladder is the preferred option, I drafted an initial concept (refer to Figure 3.4) and sought feedback from five seniors living in a retirement village.

Figure 3.4: Initial product concept sketch

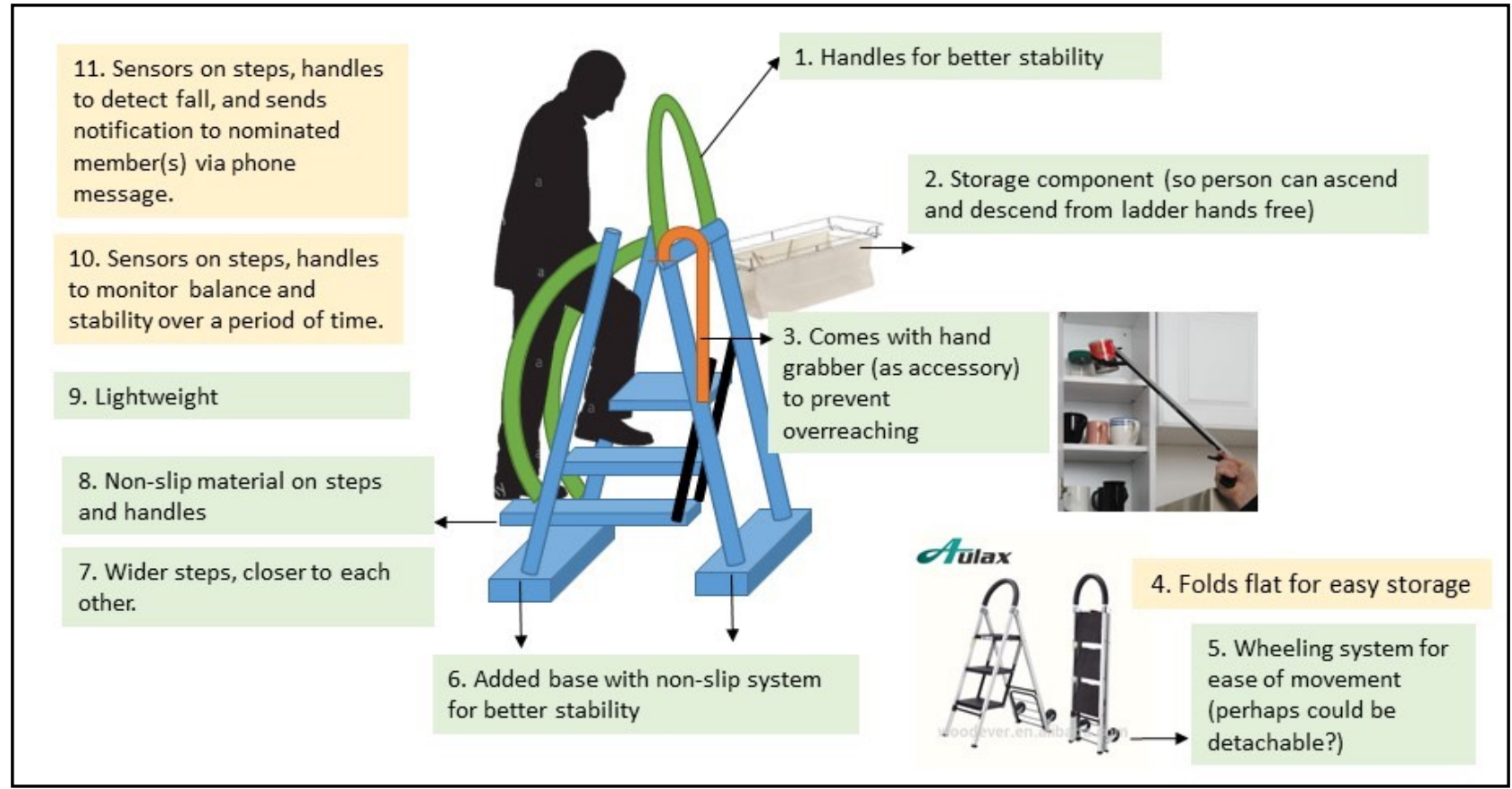

In this interview, the need for a step ladder at home was also validated. Table 3.11 shows a summary of findings. 
Table 3.11 Importance of having a step ladder at home in three time periods. (Scoring system: 1 least important - 10 most important).

\begin{tabular}{|c|c|c|c|c|c|}
\hline Time period & Senior 1 & Senior 2 & Senior 3 & Senior 4 & Senior 5 \\
\hline Before & 3 & 10 & $\begin{array}{l}\text { Had more } \\
\text { floor space } \\
\text { before due } \\
\text { to bigger } \\
\text { home, } \\
\text { hence, not } \\
\text { sure }\end{array}$ & 10 & 3 \\
\hline Now & 5 & 8 or 9 & 7 or 8 & 10 & 1 \\
\hline Future & Unsure & Unsure & Unsure & Unsure & 1 \\
\hline $\begin{array}{l}\text { Do they } \\
\text { have a step } \\
\text { ladder } \\
\text { now? }\end{array}$ & Yes & $\begin{array}{l}\text { No didn't } \\
\text { bring it with } \\
\text { her when } \\
\text { she moved } \\
\text { to retirement } \\
\text { village, but } \\
\text { looking for } \\
\text { one } \\
\text { (possibly to } \\
\text { rent). }\end{array}$ & Yes & Yes & No \\
\hline
\end{tabular}

All five seniors have had step ladders at some point in their lives. Four out of the five seniors indicated there is a need, although in varying degrees, now and before. Four were uncertain about the future indicating that "it depends" on their health. One indicates there is no longer any need now because of physical limitations and hence, there will be no need in the future.

\section{Need for an improved step ladder further validated}

Findings in Stage 2 corroborated with Findings in Stage 1 where similar attributes are 
desired. Table 3.12 shows how seniors scored different product attributes on a scale of 1 to 10 .

Table 3.12: Scores awarded to each step ladder attribute based on level of importance (where 1 is least important and 10 is most important).

\begin{tabular}{|c|c|c|c|c|c|c|}
\hline $\begin{array}{l}\text { Product } \\
\text { Attribute }\end{array}$ & Senior 1 & Senior 2 & Senior 3 & Senior 4 & Senior 5 & $\begin{array}{l}\text { Total } \\
\text { score }\end{array}$ \\
\hline Handle & 10 & 4 & 8 & 10 & 5 & 37 \\
\hline Storage bag & 8 & 5 & 9 & 5 & 5 & 32 \\
\hline Hand grabber & 1 & 1 & 9 & 1 & 1 & 13 \\
\hline Folds flat & 10 & 9 & 9 & 10 & 6 & 44 \\
\hline Wheels & 5 & 2 & 9 & 3 & 1 & 20 \\
\hline Sturdier base & 1 & 1 & 6 & 2 & 1 & 11 \\
\hline Wide steps & 10 & 3 & 8 & 8 & 1 & 30 \\
\hline $\begin{array}{l}\text { Non slip } \\
\text { material }\end{array}$ & 10 & 7 & 9 & 10 & 1 & 39 \\
\hline Lightweight & 10 & 9 & 9 & 9 & 6 & 37 \\
\hline $\begin{array}{l}\text { Fall detection } \\
\text { sensors }\end{array}$ & 1 & 1 & 6 & 9 & 1 & 18 \\
\hline $\begin{array}{l}\text { Health } \\
\text { monitoring } \\
\text { sensors }\end{array}$ & 1 & 1 & 7 & 6 & 1 & 16 \\
\hline
\end{tabular}

Top 3 attributes desired by seniors are:

1. Folds flat

2. Non-slip material

3. Handles and Lightweight (tie)

The findings did not reveal consensus on which attributes seniors would be willing to pay for as an additional cost. As a result, I developed a refined product concept based on desired features and attributes indicated by seniors, presented as a modular concept (refer to section 3.7.1). In this concept, it proposes the option to include additional 
attributes at additional costs, thereby providing consumer the options to customise their product.

\subsubsection{Development of Simple Steps}

\section{A co-developed product innovation: Simple Steps}

With reference to Figure 3.2 (on the next page), Simple Steps is an improved step ladder that comes in a modular concept, with options to include wheels, storage bag and safety sensors. It is assumed to incorporate the desired attributes of being lightweight, folds flat for easy storage, comes with non-slip materials and designed with wider steps. A tray and (detachable) storage bag was incorporated because several seniors mentioned challenges in coming down from a high place while carrying items.

Note: This concept was developed with the help of one the designers who was interviewed. 


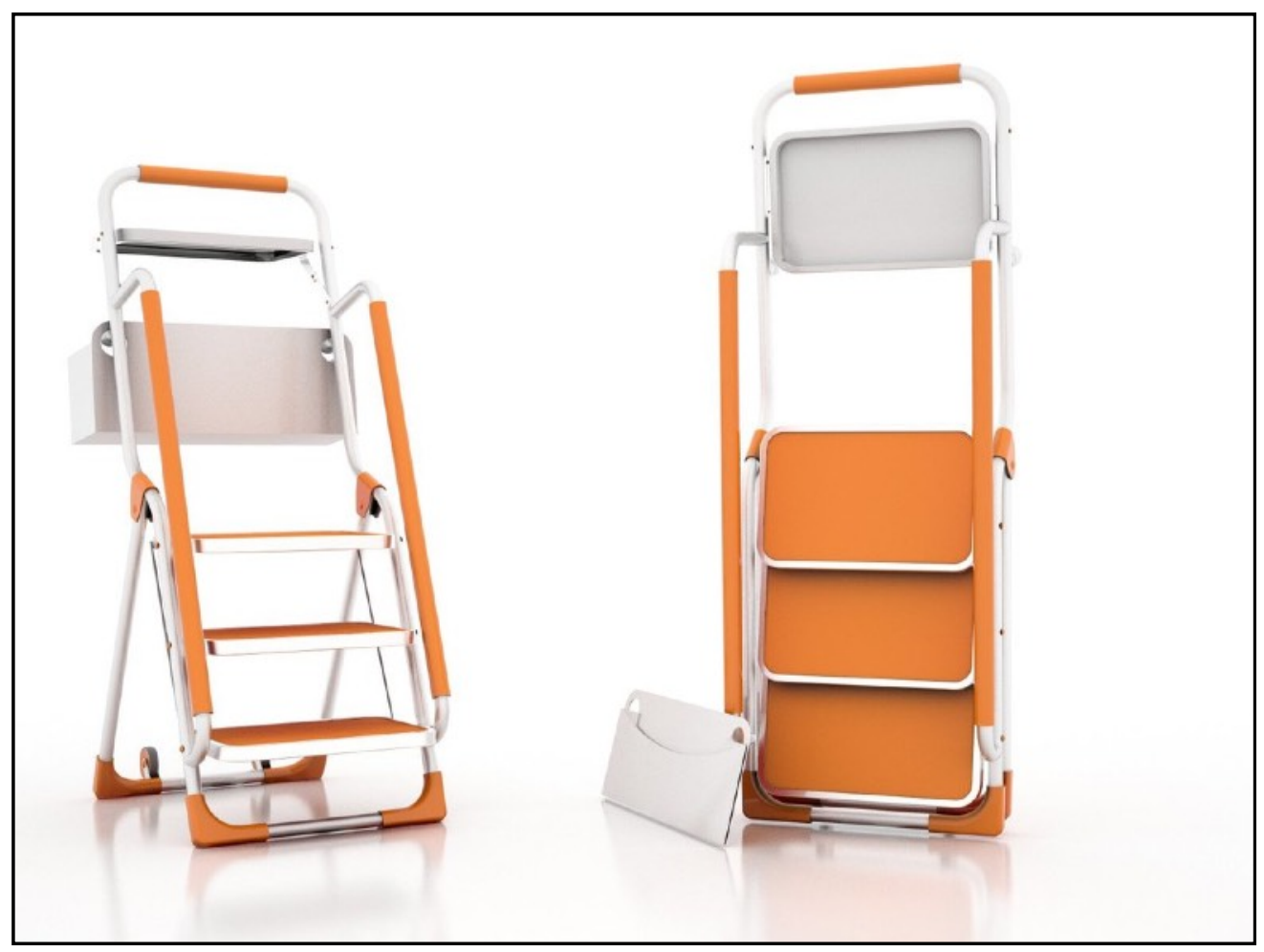

Standard product features:
- Top and side handles
- Sturdy base with quality non-slip polymer on four edges of ground
touch-points
- Quality non-slip polymer on steps and handles
- Lightweight (5kg)
- Folds out and folds up easily
- Storage tray at the top
- Dimension when in use: $1490 \mathrm{~mm} \times 670 \mathrm{~mm} \times 550 \mathrm{~mm}$
- Material: Aluminium body with non-slip polymer




\section{Stage 3 Findings: Online survey (refer to appendix 2.7)}

The online survey sought to gather consumer sentiment about Simple Steps from all stakeholders previously interviewed. This was done to understand potential commercial success of the product. Table 3.13 provides an overview of the category breakdown of respondents.

Table 3.13: Online survey respondents

\begin{tabular}{|l|c|c|c|c|c|c|}
\hline Legend: & $\begin{array}{c}\mathrm{SN}= \\
\text { Seniors }\end{array}$ & $\begin{array}{c}\mathrm{RV}= \\
\text { Retirement } \\
\text { Village } \\
\text { manager }\end{array}$ & $\begin{array}{c}\mathrm{EG}= \\
\text { Engineer }\end{array}$ & $\begin{array}{c}\mathrm{HC}= \\
\text { Healthcare } \\
\text { professional }\end{array}$ & $\begin{array}{c}\mathrm{FM}= \\
\text { Family } \\
\text { member }\end{array}$ & $\begin{array}{c}\mathrm{GV}= \\
\text { Govern } \\
\text { ment }\end{array}$ \\
\hline $\begin{array}{l}\text { Number of } \\
\text { respondents }\end{array}$ & 13 & 1 & 1 & 2 & 3 & 1 \\
\hline
\end{tabular}

\subsection{Validation of general attractiveness and desirability of Simple Steps}

Table 3.14: Tabulated responses to "Simple Steps looks appealing"

\begin{tabular}{r|c|c|c|c|c|c|}
\hline & SN & RV & EG & HC & FM & GV \\
\hline Strongly & 6 & 1 & 1 & & 3 & 1 \\
\hline Agree & & & & & & \\
\hline Agree & 6 & & & 2 & & \\
\hline Disagree & 1 & & & & & \\
\hline
\end{tabular}

Comments: "I like the new look - I like the features that are evident and the colour is easy on the eye too." - Senior (retirement village)

The majority of participants find Simple Steps visually appealing, except one senior (community) who indicated that she currently has a three-steps step stool which she finds more convenient. The step stool also functions as a high chair that does not need to be stowed and stored away. However, with the majority of positive responses, this result is encouraging as attractiveness is often the first point of interaction between consumer and product. 
Table 3.15: Tabulated responses to "Simple Steps looks safe"

\begin{tabular}{|l|c|c|c|c|c|c|}
\hline & SN & RV & EG & HC & FM & GV \\
\hline Strongly & 4 & & & & 1 & 1 \\
\hline Agree & & & & & & \\
\hline Agree & 9 & 1 & & 1 & 2 & \\
\hline Depends & & & & 1 & & \\
\hline Neutral & & & 1 & & & \\
\hline
\end{tabular}

Table 3.16: Tabulated responses to "Simple Steps looks easy to use".

\begin{tabular}{|l|c|c|c|c|c|c|}
\hline & SN & RV & EG & HC & FM & GV \\
\hline Strongly & 6 & & & & 1 & 1 \\
\hline Agree & & & & & & \\
\hline Agree & 6 & 1 & 1 & 1 & 2 & \\
\hline Neutral & 1 & & & 1 & & \\
\hline
\end{tabular}

Most perceive Simple Steps as safe and easy to use, which are good signs. However, it must be noted that the engineer indicated some safety issues with the slope angle. This must be rectified before the product goes into production.

Table 3.17: Tabulated responses to "Simple Steps looks sturdy"

\begin{tabular}{|l|c|c|c|c|c|c|}
\hline & SN & RV & EG & HC & FM & GV \\
\hline $\begin{array}{l}\text { Strongly } \\
\text { Agree }\end{array}$ & 6 & & & & 1 & 1 \\
\hline Agree & 7 & 1 & & & & \\
\hline Neutral & & & 1 & 2 & & \\
\hline
\end{tabular}

Comments: "I would need to test whether the wheels could accidentally be left in the open position" - Family member 
Most perceive Simple Steps as sturdy. However, the comment made by one of the family members suggest the importance of making Simple Steps available to be physically tested by potential customers.

\subsection{Clarification and validation of product attributes to develop}

Table 3.18: Tabulated responses to preference for way sensor is incorporated within Simple Steps

\begin{tabular}{|c|c|c|c|c|c|c|}
\hline $\begin{array}{l}\text { Sensor } \\
\text { type }\end{array}$ & SN & $\mathbf{R V}$ & EG & $\mathrm{HC}$ & FM & GV \\
\hline Embedded & 8 & 1 & 1 & 1 & 2 & 1 \\
\hline Wearable & 5 & & & 1 & 1 & \\
\hline \multicolumn{7}{|c|}{$\begin{array}{l}\text { Comments: } \\
\text { - "It is better to be embedded in the ladder as old people can be quite forgetful in } \\
\text { wearing accessory while using the ladder." - Senior (in the community) } \\
\text {. "Sensor linked to my medical alarm bracelet which I already wear" - Senior } \\
\text { (retirement village) } \\
\text { - "I don't see the value in personal sensors if you are looking to link with this } \\
\text { product. Either have it embedded or leave it out." - Physiotherapist }\end{array}$} \\
\hline
\end{tabular}

Majority of respondents prefer to have sensors embedded within the step ladder. However, there are also some participants who would consider wearables for more practical reasons such as seniors who already possess a wearable medical alarm device. This suggests some opportunities in pursuing wearable technologies, perhaps as another form of additional product feature. However, it it not within the scope of this project to further develop this option. 
Table 3.19: Tabulated responses to additional features willing to pay for

\begin{tabular}{|c|c|c|c|c|c|c|}
\hline $\begin{array}{l}\text { Additional } \\
\text { features }\end{array}$ & SN & $\mathbf{R V}$ & EG & $\mathrm{HC}$ & FM & GV \\
\hline None & 1 & 1 & & & & \\
\hline Storage & 3 & & 1 & 2 & 1 & 1 \\
\hline Sensor & 6 & & 1 & 1 & 1 & 1 \\
\hline Wheels & 9 & & & 2 & 3 & 1 \\
\hline
\end{tabular}

*Note: This question allowed multiple selection of answers.

\section{Comments:}

"Ideally I would like to include all optional features however it would be dependent on cost." -Government representative

Most popular attributes that seniors are willing to pay for, in order of popularity:

1. Wheels 2. Sensor 3. Storage

\subsection{Competitor Analysis}

Table 3.20: Tabulated response to how Simple Step compares with what is available in the market

\begin{tabular}{|c|c|c|c|c|c|c|}
\hline & SN & RV & EG & HC & $F M$ & GV \\
\hline $\begin{array}{l}\text { Much } \\
\text { better }\end{array}$ & 9 & 1 & 1 & & 1 & 1 \\
\hline $\begin{array}{l}\text { Somewhat } \\
\text { better }\end{array}$ & 3 & & & 2 & 2 & \\
\hline $\begin{array}{l}\text { Somewhat } \\
\text { worse }\end{array}$ & 1 & & & & & \\
\hline \multicolumn{7}{|c|}{$\begin{array}{l}\text { Comments: } \\
\text { - "Ours has no side rails" - (Senior, retirement village ) } \\
\text { - "I like the inclusion of the rails and the ability to place items on a tray/bag" - } \\
\text { (Occupational therapist) }\end{array}$} \\
\hline
\end{tabular}

In general, respondents perceive Simple Steps as better than the competition. 
Table 3.21: Simple Steps - a product worth recommending?

\begin{tabular}{|l|c|c|c|c|c|c|}
\hline & SN & RV & EG & HC & FM & GV \\
\hline $\begin{array}{l}\text { Very } \\
\text { likely }\end{array}$ & 5 & & & & 1 & 1 \\
\hline Likely & 7 & & & 1 & 1 & \\
\hline Neutral & 1 & & & & & \\
\hline Depends & & 1 & 1 & 1 & 1 & \\
\hline
\end{tabular}

Most seniors seem willing to recommend Simple Steps which is a good indication. This supports word of mouth marketing strategy. Other stakeholders seem more cautious about recommending. Perhaps they are aware of their role as an "expert". Hence, they would require more details and understanding of product before making recommendations. It would be important to make such information available to these stakeholders (influencers) in order to convince them.

\section{Other comments:}

A few enquired about a step ladder that could go higher. This is something to take note of as a potential product extension.

Some suggestions for improvements were also given:

- Physiotherapist : Wider and larger points of contact for base to floor

- Senior: To have a way of stopping a backward step when balance fails

The willingness by participants to provide feedback suggest stakeholders have a vested interested in the product development and creation of Simple Steps. I consider this an encouraging sign and a further validation that Simple Steps is an innovation that would be accepted in the commercial market. This also highlights a strong case for a co-creation business model with input from stakeholders. 


\subsection{Business model strategy considerations}

\section{Key Decision-making Considerations}

Table 3.22: Key decision making considerations based on recurring comments from Stage $1 \& 2$ research

\begin{tabular}{|c|c|c|c|c|c|c|}
\hline & SN & $\mathbf{R V}$ & EG & $\mathrm{HC}$ & FM & GV \\
\hline Good reviews & 5 & 0 & 1 & 2 & 3 & 1 \\
\hline $\begin{array}{r}\text { Recommended } \\
\text { by someone I } \\
\text { know }\end{array}$ & 4 & 0 & 0 & 1 & 3 & 1 \\
\hline $\begin{array}{r}\text { Able to test in } \\
\text { person }\end{array}$ & 10 & 1 & 1 & 2 & 3 & 1 \\
\hline $\begin{array}{r}\text { Adheres to } \\
\text { AUS:NZ } \\
\text { standards }\end{array}$ & 11 & 0 & 1 & 2 & 2 & 1 \\
\hline $\begin{array}{r}\text { Most } \\
\text { affordable }\end{array}$ & 6 & 0 & 0 & 1 & 2 & 0 \\
\hline
\end{tabular}

\section{Implications for business model:}

It appears that the most important factor is that the step ladder adheres to AUS:NZ standards, followed by the ability to test the product in person. Affordability also ranks relatively high for seniors. Therefore, in positioning Simple Steps, it must be priced at a relatively competitive pricing. However, the importance of adhering to safety standards suggests product safety and quality is critical. It would be more important to strike a good balance between cost and quality, and focus more on offering value for money, instead of a low-cost strategy. The importance of being able to test the product in person makes it essential for the business model to prioritise product availability in physical stores, and rules out employing an online sales model. 


\section{Price sensitivity at two different price points of $\$ 100$ and $\$ 150$}

Table 3.23: Tabulated responses to "How likely will you buy Simple Steps at $\$ 100$ ?"

\begin{tabular}{|c|c|c|c|c|c|c|}
\hline & SN & $\mathbf{R V}$ & EG & $\mathrm{HC}$ & $\mathbf{F M}$ & GV \\
\hline Very likely & 4 & & & & 2 & 1 \\
\hline Likely & 5 & 1 & 1 & 2 & 1 & \\
\hline Neutral & 1 & & & & & \\
\hline Depends & 2 & & & & & \\
\hline No need & 1 & & & & & \\
\hline
\end{tabular}

\section{Comments:}

- "Depends on need to upgrade existing ladder" - Senior (retirement village)

- 'Depends on availability - i.e. where sold. If easily available, then 'Very Likely' Senior (community)

Table 3.24 Tabulated responses to "How likely will you buy Simple Steps at Price at $\$ 150 ? "$

\begin{tabular}{|l|c|c|c|c|c|c|}
\hline & SN & RV & DE & HC & FM & GV \\
\hline Very likely & 1 & & & & 2 & \\
\hline Likely & 5 & & 1 & 1 & 1 & 1 \\
\hline Neutral & 3 & & & 1 & & \\
\hline Depends & 1 & 1 & & & & \\
\hline Unlikely & 3 & & & & & \\
\hline
\end{tabular}

\section{Comments:}

- "One third more is not inconsiderable." - Senior (retirement village)

- "The choice of buying the ladder would depend on my likelihood of falls. Also I live on a very limited income and there are two of us sharing expenses. We also have access to assistance by the property maintainers who are often called in to change light bulbs and attend to any work that requires a ladder. However if I were still at home in a residential address I may require a ladder of my own and this suggested model would be perfect." - Senior (retirement village) 


\section{Implications for business model:}

Seniors seem to be quite price sensitive. Finding appears to further validate the importance of keeping the product affordable. The above results suggests that it will be crucial to keep product manufacturing costs low. At the same time, the distribution strategy should ensure the product is available in physical stores. Although retirement villages have been identified as a potential intermediary, demand for Simple Steps may be higher among seniors within the community. However, results from this research have shown that some seniors living in retirement villages do desire to access high places independently, even though there are on-site tradesmen available. Hence, it is still worthwhile to include retirement villages as part of the distribution strategy. Moreover, Simple Steps could be promoted as a safer tool for older workers in the retirement village.

\section{Promotion and distribution considerations}

\section{Information search channels: Google, catalogue, emailer}

When asked (in a generic sense) about how they would go about searching for a safer product for access to high spaces or mobility tools, the most commonly cited source of information was through the Internet. More specifically, to "Google". However, those in their late 80 s tend to be less keen to search on the internet, preferring to go directly to stores or seek advice from others. A few cited magazine catalogues they receive by post, and one mentioned an e-newsletter.

\section{Reference groups (influencers): Peers, family, RV staff, GP or healthcare staff} Some mentioned they would seek expert advice from healthcare professionals, such as their family doctor, a regular chemist. For a few of the participants who live in a retirement village, they would seek advice from retirement village staff. Several participants also cited that they would ask for opinions and recommendations from peers, and some also mentioned family members. 


\section{Marketing message to emulate/avoid (based on current perceptions of how the market targets older people)}

\section{Seniors' perspectives}

Seniors were relatively divided on this topic. A few don't see themselves as "seniors", and that seniors were people in their "80s" or "90s". In contrast, a 90 year old man indicated he considers his younger days during the time he was in his $80 \mathrm{~s}$. However, a 60 year old man indicated that he saw himself as a senior because of his observations of his health declines, as well as, how others perceived him (i.e people treating him differently such as offers of assistance, which made him more aware of his "seniority").

Quite a number of seniors indicated they were unaware of products catered to older consumers. Several mentioned that they "switched off" when they saw advertisements targeted at older people and that they don't think they are considered "seniors". Some of the language used to describe their feelings towards senior-oriented products include: "sceptical", "suspicious", "stereotypical" and "manipulative".

However, there were also others who indicated that they think being marketed (as an older person) is a good thing as they would like more information about products catered to them. A few expressed more positive attitudes, citing the SuperGold card as something desirable, using words such as "good" "brilliant" and "wonderful" to describe it.

In general, there was a lack of awareness of what is available out there, and also where to look for products. A significant number of seniors expressed a desire to know more about products catered to their needs on the condition that it something they really need, and is proven and tested product by experts.

This highlights a need to reach out to seniors through effective avenues (such as through channels they frequent), and the necessity for information to be presented in a desirable and convincing manner. The Business Case further discusses this. 


\section{Other stakeholders}

One of the family members described the way products are marketed as "fearmongering" and suggests that marketing message should be more about "improving the quality of life".

There was consensus among government, voluntary organisations and retirement village personnel that most products in the market for older people are "ugly" and "not designed with aesthetics in mind". There was further elaboration that they believe it is important that things (for older people) "still look good" and "look cool". Some examples of good marketing and attractive products were given, such as the Nip-Glide (this is discussed in the Business Case, Chapter 6). It appears this specific example is considered positive marketing because it takes aesthetics as a key attribute and that the message portrays ageing as staying active and independent instead of vulnerable and needing assistance.

\section{Analysis}

This suggest a need to develop better communication strategies when it comes to seniors. The lack of awareness also suggests opportunities for greater public education and an "untapped" area in the market. The acceptance of one as an "older person" varies and is likely dependent on individual perspectives and perhaps the environment that one is in or have been in. This points to a need for further categorisations of older consumers into sub-segments, instead of generalising "older consumers" as a singular group.

\section{Product manufacturing and resource considerations}

\section{Can it be developed?}

The key takeaway is that, technologically, "anything is possible" in today's climate. It was suggested to consider working with a university design or engineer team, Callaghan Innovation, or a New Zealand based step ladder manufacturer such as Ullrich.

\section{Intellectual Property (IP)}

My interviews with designers and engineers also directed me to consider certain avenues for IP Protection. For example, the shape of the step ladder could be 
trademarked or as a design patent. For a sensor device, the algorithm could be patented. However, there is a general advice that patents, although useful, have to be carefully considered and sometimes other ways of protecting intellectual property could be more cost effective, such as trade secrets.

\section{Resources}

There was no specific organisation identified that would fund the project completely. However, the key takeaway was that opportunities exist through multiple avenues and it would be feasible to gather resources (for different purposes) from a range of sources. For example, Callaghan Innovation or universities could assist in product development and partial research grants are available. It was implied that ACC together with District Health Boards, might be interested to look into the project if a strong case can be made that the product innovation aids in fall prevention among older people - an area that ACC is particularly concerned about. Participants mentioned Office for Seniors (Super Seniors), Age Concern, Grey power and Retirement Villages Association as possible organisations to approach for further discussions or explorations. These institutions would likely be interested in some form or another, as long as the goal and outcome is bettering the interests of older people. Direct financial support may not be likely, however they would be able to facilitate connections to interested parties such as corporates or investors.

\subsection{Summary of stakeholders' validation of market and product opportunities}

Table 3.25 Summary of stakeholders' validation of market and product opportunities

\begin{tabular}{l|l|l|}
\hline \multicolumn{2}{|l|}{ Participant } & $\begin{array}{l}\text { Key findings } \\
\text { support? }\end{array}$ \\
\hline $\begin{array}{l}\text { Seniors (end } \\
\text { consumers) }\end{array}$ & $\begin{array}{l}\text { Most seniors are supportive of } \\
\text { the development of a better tool } \\
\text { to access high places at home. } \\
\text { Most respondents to the online } \\
\text { survey also validated the appeal } \\
\text { of Simple Steps. }\end{array}$ & $\begin{array}{l}\text { Relatively strong support, } \\
\text { suggesting market and product } \\
\text { opportunities. }\end{array}$ \\
\hline
\end{tabular}




\begin{tabular}{|c|c|c|}
\hline Participant & Key findings & $\begin{array}{l}\text { Analysis: Validation of } \\
\text { support? }\end{array}$ \\
\hline $\begin{array}{l}\text { Family } \\
\text { members } \\
\text { (Influencers) }\end{array}$ & $\begin{array}{l}\text { Family members varied in } \\
\text { opinions but appear to think } \\
\text { accessing high places is risky for } \\
\text { seniors. Therefore, the general } \\
\text { consensus was that they would } \\
\text { rather their senior family } \\
\text { members not engage in home } \\
\text { activities requiring access to high } \\
\text { places. However, their feedback } \\
\text { on Simple Steps was generally } \\
\text { positive. }\end{array}$ & $\begin{array}{l}\text { Moderate support. Might need } \\
\text { to convince this stakeholder } \\
\text { group to consider the need from } \\
\text { seniors' perspectives through } \\
\text { educational and awareness } \\
\text { campaigns. It would be } \\
\text { important to focus on } \\
\text { communicating safety aspects }\end{array}$ \\
\hline $\begin{array}{l}\text { Healthcare } \\
\text { professionals } \\
\text { (influencers) }\end{array}$ & $\begin{array}{l}\text { Healthcare professionals varied } \\
\text { in their opinions. Physiotherapist } \\
\text { appeared keen on health } \\
\text { monitoring sensors, while } \\
\text { occupational therapist preferred } \\
\text { task avoidance. }\end{array}$ & $\begin{array}{l}\text { of the innovation in order to } \\
\text { gain the support of this group of } \\
\text { stakeholders. }\end{array}$ \\
\hline $\begin{array}{l}\text { Designers/ } \\
\text { Engineers } \\
\text { (enablers) }\end{array}$ & $\begin{array}{l}\text { Validated the feasibility of the } \\
\text { product concept and provided } \\
\text { assurance that technology exists. } \\
\text { However, they did advise on } \\
\text { conducting more research on } \\
\text { scalability of production. }\end{array}$ & $\begin{array}{l}\text { Quite strong support. Apart } \\
\text { from validating the possibility of } \\
\text { production, participants } \\
\text { expressed interest in the project } \\
\text { and product. More research } \\
\text { needs to be done to understand } \\
\text { actual manufacturing costs. }\end{array}$ \\
\hline
\end{tabular}




\begin{tabular}{|c|c|c|}
\hline Participant & Key findings & $\begin{array}{l}\text { Analysis: Validation of } \\
\text { support? }\end{array}$ \\
\hline $\begin{array}{l}\text { Retirement } \\
\text { Village } \\
\text { managers } \\
\text { (intermediaryl } \\
\text { influencer) }\end{array}$ & $\begin{array}{l}\text { Although they acknowledge their } \\
\text { preference for older people to call } \\
\text { upon retirement village staff for } \\
\text { assistance, they recognise the } \\
\text { need for independence. Both } \\
\text { managers confirmed that regular } \\
\text { supplier exhibitions (where } \\
\text { product and services for older } \\
\text { people are showcased) are held } \\
\text { on premises on a regular yearly } \\
\text { basis. }\end{array}$ & $\begin{array}{l}\text { Relatively strong support. } \\
\text { Expressed willingness to } \\
\text { recommend Simple Steps to } \\
\text { residents and allow access to } \\
\text { supplier exhibitions. This } \\
\text { validates the intermediary role } \\
\text { of retirement villages. }\end{array}$ \\
\hline $\begin{array}{l}\text { Voluntary and } \\
\text { government } \\
\text { representatives } \\
\text { (enablerl } \\
\text { influencer) }\end{array}$ & $\begin{array}{l}\text { Mainly supportive of the initiative } \\
\text { of falls/injury prevention. } \\
\text { Independence is also seen as an } \\
\text { important topic but the focus is on } \\
\text { safety. }\end{array}$ & $\begin{array}{l}\text { Moderate support. It appears } \\
\text { this stakeholder group might } \\
\text { take a more passive role in } \\
\text { product development but could } \\
\text { offer secondary support such as } \\
\text { helping to raise awareness of } \\
\text { an older person's perspective. }\end{array}$ \\
\hline
\end{tabular}

In general, there is relatively good support from all stakeholders for this project. In particularly, findings have showed that there is strong support from end-consumers (seniors), who are the most important stakeholders. Therefore, market and product assumptions have been validated. 


\section{CHAPTER 4 - DISCUSSION}

This chapter provides key implications for the commercialisation process (i.e proposing a business model) based on further analysis of major findings within the Business Canvas Model analysis. This chapter will start with a summary of the business model, while sections 4.2 to 4.6 elaborate on the evidence-based analysis process. Section 4.7 suggests implications beyond the scope of this project.

\subsection{Summary Of Business Model}

A feasible business model for Simple Steps that would facilitate commercialisation is one that focuses on collaborations with key stakeholders.

- 1) Collaborate and consult with its target customers i.e older people. It should cocreate innovations with older consumers, in order to develop and deliver products catered to their needs.

- $\quad$ Simple Steps is the specific outcome of this project. However, the modular design philosophy that enables progressive acceptance of innovation should become a core company and brand value.

- 2) Collaborate with other stakeholders such as resource and technology suppliers, as well as distribution and promotion partners, in order to optimise costs. It should be "lean and mean" and save on operating costs so that prices can be kept low for consumers. For example, retail presence should be made available by leveraging on distribution and retail partners instead of setting up fully owned and operated stores. Promotion can be done mainly through the Internet, word-of-mouth, and through the community, to save on advertising costs - in particular, working with both government and voluntary organisations with an interest in the wellbeing of older people. 


\subsection{Elaboration of business model components}

Figure 4.1: Overview of Business Model Canvas (BMC)

\begin{tabular}{|c|c|c|c|c|c|}
\hline \multirow[t]{2}{*}{$\begin{array}{l}\text { Key Partners } \\
\text { (Key } \\
\text { Partners) } \\
\text { Designers, } \\
\text { engineers. } \\
\text { Retirement } \\
\text { villages } \\
\text { Age Concern, } \\
\text { Office for Seniors }\end{array}$} & $\begin{array}{l}\text { KeyActivities } \\
\text { (Key } \\
\text { Activities) } \\
\text { - Find a team } \\
\text { - Set up a company } \\
\text { - Look into grants }\end{array}$ & \multirow{2}{*}{\multicolumn{2}{|c|}{$\begin{array}{l}\text { Value Propositions } \\
\qquad \text { (Value } \\
\text { Propositions) } \\
\text { - Developed for } \\
\text { older people } \\
\text { - Safer } \\
\text { - Aesthetically } \\
\text { pleasing } \\
\text { - Modular } \\
\text { - Affordable }\end{array}$}} & $\begin{array}{l}\text { Customer Relationship: } 2 \\
\text { (Customer } \\
\text { Relationships) } \\
\text { - Long-term, } \\
\text { collaborative, } \\
\text { co-creation }\end{array}$ & \multirow{2}{*}{$\begin{array}{l}\text { Customer Segments } \\
\text { (Customer } \\
\text { Segments) } \\
\text { - Seniors, could be } \\
\text { sub-segmented } \\
\text { based on age } \\
\text { band (i.e young } \\
\text { old and older old) } \\
\text { - Family members } \\
\text { of seniors } \\
\text { (although not a } \\
\text { major focus) }\end{array}$} \\
\hline & $\begin{array}{l}\text { Key Resources } \\
\text { (Key } \\
\text { Resources) } \\
\text { - Find a team }\end{array}$ & & & $\begin{array}{l}\text { Channels } \\
\text { (Channels) } \\
\text { - Online } \\
\text { promotion but } \\
\text { physical store } \\
\text { presence }\end{array}$ & \\
\hline \multicolumn{6}{|l|}{ Cost Structure } \\
\hline
\end{tabular}

wwwbusinessmodelgeneration.com

The templates lene ate made aralatle on the ome CC lisence terms as the crignal canvas.

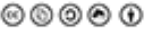

\subsubsection{Key Partners}

There are several types of partners to be considered for this project. They can be categorised as product, market and intermediaries.

In terms of product development, based on discussions with engineers and designers I have interviewed, it was suggested that I consider working with a university-supported organisation or a team of undergraduate students who may be keen to work on a practical project. For example, Callaghan Innovation. Alternatively, there is the possibility of working with an existing manufacturer in a related industry on a collaboration basis.

For the market sector, as seniors are the main target consumers, it would be important to work with organisations which have regular access and interaction with this segment of the population. Both official and unofficial partnerships would be highly beneficial in getting information and marketing messages to the target consumers. Some organisations that 
would be relevant include, Age Concern, Office for Seniors (Super Seniors), Grey Power, ACC and Retirement Villages Association.

Lastly, potential distributors of the product would need to be established. As a first step, it appears possible to work with retirement villages, such as through participating in their regular supplier exhibition fairs. Further distribution strategies will be discussed in the Business Case.

\subsubsection{Key Activities}

As the research concluded with the confirmation of a feasible concept in terms of consumer acceptance and general technological and technical design and engineering possibilities, the next key steps would be to develop the proposed product and test it physically. It would be essential to continue with the iteration process of feedback, refine and develop, and so forth. Concurrently, the foundations of creating a business have to be explored such as the registration of a company, putting a team together and exploring funding possibilities. More details will be discussed in the Business Case.

\subsubsection{Key Resources}

At the point of writing, it is difficult to identify tangible resources, such as capital or equipment. However, through this research, I have obtained several valuable intangible resources. One of it is knowledge. The in-depth understanding of older consumers and their needs and motivations has been crucial in informing the product innovation and development process. Secondly, this research has enabled me to discover potential partners to work with and I have since gathered a network of advisors for further development. Thus, I have gained the knowledge to search in the right places for more necessary resources.

I have also gained a group of potential ready customers who have indicated their willingness to purchase Simple Steps if it can be produced. They will also likely be able to assist in the promotion of the product, thereby achieving the goal of word-of-mouth marketing. 
Table 4.1: Summary of Key Partners, Activities and Resources

\begin{tabular}{|c|c|c|c|}
\hline & Key partners & Key Activities & Key resources \\
\hline $\begin{array}{l}\text { Product } \\
\text { (supplier) }\end{array}$ & $\begin{array}{l}\text { University (lab) } \\
\text { Callaghan } \\
\text { Innovation. }\end{array}$ & $\begin{array}{l}\text { Establish relationship, } \\
\text { put together a team, } \\
\text { apply to be part of } \\
\text { Callaghan's } \\
\text { innovation } \\
\text { programme. }\end{array}$ & $\begin{array}{l}\text { University networks. } \\
\text { For example, Victoria } \\
\text { University of } \\
\text { Wellington's } \\
\text { Engineering and } \\
\text { Design school. }\end{array}$ \\
\hline $\begin{array}{l}\text { Market } \\
\text { (customers and } \\
\text { influencers) }\end{array}$ & $\begin{array}{l}\text { Organisation and } \\
\text { places with access } \\
\text { to older people (RV, } \\
\text { NGOs, Gov, } \\
\text { communities etc) }\end{array}$ & $\begin{array}{l}\text { Establish } \\
\text { relationships with } \\
\text { organisations etc. }\end{array}$ & $\begin{array}{l}\text { Community and } \\
\text { organisation networks } \\
\text { (Retirement Villages, } \\
\text { seniors, Age Concern } \\
\text { etc) }\end{array}$ \\
\hline \multirow[t]{2}{*}{ Intermediaries } & Retirement village & Establish relationship. & $\begin{array}{l}\text { Build on existing } \\
\text { networks. }\end{array}$ \\
\hline & & Set up company & \\
\hline
\end{tabular}

\subsubsection{Customer relationship}

This project started with the intention of developing an innovation by understanding the needs of the target consumers. Thus, a co-creation relationship was assumed and research findings have also validated its effectiveness in creating products that meet the needs of consumers.

As can be seen from the research methodology, as well as through the progress of the product development, Simple Steps is an outcome based on continuous consultation with key stakeholders, especially with the target consumers. Many older people have also indicated that they wished more people would come and talk to them in order to find out what issues they are facing. This suggests there are commercial opportunities to fill such gaps. It would be desirable for a business model to establish a strong, consultative and collaboration relationship with older consumers for the long-term. This would reflect and truly deliver on the philosophy of developing assistive technology for older people. From the interviews, it was revealing that the majority of respondents did not like the current marketing message towards seniors. It is thus, important to create a positive first impression with the appropriate message in order to build good consumer relationships. 
Table 4.2: Customer relationship and segments

\begin{tabular}{|l|l|l|}
\hline \multicolumn{2}{|c|}{ Customer relationship } & \multicolumn{1}{l}{ Customer segments } \\
\hline $\begin{array}{l}\text { Product } \\
\text { development }\end{array}$ & Co-creation, feedback & $\begin{array}{l}\text { Seniors: age, gender, } \\
\text { dwelling, }\end{array}$ \\
\hline $\begin{array}{l}\text { Market } \\
\text { development }\end{array}$ & Word of mouth, loyalty (long-term) & \\
\hline $\begin{array}{l}\text { Channels } \\
\text { (sales and } \\
\text { after-sales) }\end{array}$ & $\begin{array}{l}\text { Online, community, physical stores, }, \\
\text { events, fairs }\end{array}$ & $\begin{array}{l}\text { Organisations, family } \\
\text { members }\end{array}$ \\
\hline
\end{tabular}

\subsubsection{Customer segments}

Research findings revealed that apart from seniors, who were assumed to be the main customer segment, there are also other potential customers. For example, some family members indicated their willingness and desire to purchase assistive technology for their older family members. This would imply that there is potential for the business model to pursue a multi-segmented strategy. It also implies a need to develop a separate strategy that is tailored to the buying behaviours of the family members of seniors. Additionally, the segment of older people could be further categorised based on different sub-segment characteristics such as demographics and psychographics. For example, this includes segments based on level of technology acceptance, i.e early adopters or late adopters and degree of physical abilities. It would be important to note the need for different communication and marketing strategies in order to target different segments.

It is also important to note the transitions of ageing. For example, a young old might think and behave quite differently from the older people. Within the senior segment, it is critical to acknowledge the different age range as well. 


\subsubsection{Channels}

When it came to information search, most interviewees indicated their first instinct would be to "google" on the internet, with a few mentioning that they might ask retirement village staff for advice or their peers and family. A small minority indicated they might look through catalogues sent to their homes, or electronic newsletters that they receive in the email inboxes. It is important to highlight that while seniors are willing to search for information online, they expressed a strong desire to test a step ladder in a physical store before making a purchase.

From the research interviews, the most commonly cited place to purchase a step ladder would be Bunnings or Mitre 10. When the question was expanded to include a more generic category of safety tools for older people, the majority of senior interviewees were unsure what stores were available, but a few mentioned Mobility Centre.

Other responses contributed by health care professionals and organisation representatives included direct sales representatives and at the hospital store. Retirement village managers also confirmed that exhibitions of external suppliers who cater products to older people are regularly held in-house.

This implies that is it critical to create a good online presence, such as developing a quality website with all necessary information and an easy-to-navigate interface. At the same time, it would be crucial to ensure that Simple Steps are available in physical locations in order to facilitate purchase. As earlier mentioned in the Key Partners section, the first step is to find out how to be part of the exhibitions held at retirement villages. Beyond retirement villages, the product could be demonstrated at relevant conferences related to ageing (e.g Age Concern conferences) and/or innovation and design (e.g Design4Health) to generate awareness and interest. Consignment ${ }^{1}$ partnerships with a range of boutiques, shops, galleries could also be established to ensure availability of Simple Steps in more places.

${ }^{1}$ Consignment is an arrangement in which an item is placed in the care of a business partner for purpose of selling. A commission is typically given to the consignee when item is sold. 


\subsubsection{Value propositions ${ }^{2}$}

Based on the final survey results, it appears that Simple Steps is perceived by participants as visually more appealing when compared to what is currently available in the market. This suggests that being aesthetically pleasing and attractive could be considered one of the value propositions. The modular design where there is flexibility to customise the type of product features, is also something that would serve as a unique offering and could be a competitive advantage. Having the possibility of an embedded fall detection sensor also adds to the competitive edge.

The survey results revealed that the most important factors in the decision making process were: adheres to safety AUS:NZ standards, being able to test the product in a physical store before purchase, and is affordable. Hence, Simple Steps should endeavour to deliver on those points in order to be the considered the step ladder of choice.

From a commercial perspective, it is important to remain competitive on several key aspects instead of delivering only on one unique selling point, as having a sole feature advantage could be easily replaceable or easily copied. However, if the value propositions or competitive advantage exists as a combination and amalgamation of several factors, such as product offerings, customer relationships, brand reputation and so on, it would be more likely to win the hearts of consumers and make them more willing to purchase the product.

Table 4.3 provides a summary of value propositions that Simple Steps should include.

Table 4.3: Value Propositions

\begin{tabular}{l|ll}
$\begin{array}{l}\text { Value } \\
\text { Proposition }\end{array}$ & Customer needs and wants & $\begin{array}{l}\text { Production/Business } \\
\text { capabilities } \\
\text { (recommendations) }\end{array}$ \\
\hline Function & Safe, adheres to NZ standards & NZ made \\
& Easy to use, enables independence & $\begin{array}{l}\text { Well-tested, experienced } \\
\text { manufacturer }\end{array}$ \\
& &
\end{tabular}

\footnotetext{
2 Value Propositions are product and service features that satisfy a customer need/create value for a customer (Osterwalder, 2010).
} 


\begin{tabular}{|c|c|c|}
\hline \multicolumn{2}{|c|}{ Proposition } & $\begin{array}{l}\text { Production/Business } \\
\text { capabilities } \\
\text { (recommendations) }\end{array}$ \\
\hline \multirow[t]{2}{*}{ Design } & Modular & $\begin{array}{l}\text { Good designer, good } \\
\text { communication with older } \\
\text { people }\end{array}$ \\
\hline & $\begin{array}{l}\text { For older people, attractive (doesn't } \\
\text { stereotype older people - looks } \\
\text { "young") }\end{array}$ & $\begin{array}{l}\text { Good quality, material/ } \\
\text { mechanisms, }\end{array}$ \\
\hline Cost & Affordable & $\begin{array}{l}\text { Establish supplier partnership } \\
\text { or work with university, apply } \\
\text { for grants from Callaghan } \\
\text { Innovation. }\end{array}$ \\
\hline Channel & $\begin{array}{l}\text { Easy to find (information on) and } \\
\text { buy - availability to test and buy }\end{array}$ & $\begin{array}{l}\text { Good website, marketing } \\
\text { collaterals, sales network in } \\
\text { convenient places, delivery } \\
\text { services }\end{array}$ \\
\hline
\end{tabular}

\subsubsection{Cost structure}

Findings revealed that cost is a significant concern in the purchase decision. Therefore, in positioning Simple Steps, it must have a relatively competitive pricing. This also relates to cost of production as the final selling price affects the amount of profit margin that can be achieved.

Although cost is a concern, it is also important to note, based on the online survey, the top decision factor is whether the step ladder adheres to the AUS;NZ regulatory standards. This suggests that product safety and quality are also critical. It would be more important to strike a good balance between cost and quality, and focus more on offering value for money, instead of simply pursuing a low-cost strategy. Areas where cost can be minimised include sales (retail) operations and promotional expenses. The business case will discuss cost and resource analysis in further detail. 


\subsubsection{Revenue streams}

The most likely revenue stream would come from asset sales i.e sale of Simple Steps. There are several sources of revenue within the concept due to the modular design system, where each additional attribute comes at an extra cost. For example, should the step ladder be priced at $\$ 100$, there could be additional revenue from selling the add-ons. There could also be potential to develop a range of other accessories that are related to the step ladder, such as the hand grabber, which was cited by several participants as something they have come across and thought might be useful. However, as a first step, it would be sensible, from a capital expense perspective, to focus on a core product. To facilitate the purchase process, sales strategies such as discounts, customer loyalty programme and warranties should be implemented.

Table 4.4: Summary of cost structure and revenue implications

\begin{tabular}{|l|l|l|}
\hline \multicolumn{2}{|l}{ Cost structure } & Revenue Streams \\
\hline $\begin{array}{l}\text { Product } \\
\text { development }\end{array}$ & $\begin{array}{l}\text { Minimise development } \\
\text { cost }\end{array}$ & $\begin{array}{l}\text { Seek funding (crowdfunding, investors } \\
\text { seed funding, development or securing } \\
\text { IP for sale, establishing brand (to } \\
\text { secure future brand value). }\end{array}$ \\
\hline \begin{tabular}{l|l|l|} 
Product \\
production
\end{tabular} & $\begin{array}{l}\text { On-demand production or } \\
\text { small scale productions, } \\
\text { deferred payment option }\end{array}$ & $\begin{array}{l}\text { Start small scale selling, e.g approach } \\
\text { retirement villages, communities and } \\
\text { organisations and personal networks. }\end{array}$ \\
\hline & & \\
\hline
\end{tabular}




\section{Cost structure}

\section{Product sales} launch

\section{Revenue Streams}

Make Simple Steps attractive to buy: cost (try not to incur shop rent, retail staff etc).

Streamline operations.

Keep team "lean and mean".

Consignment partnerships and low cost promotional strategies.
E.g Offer GoldCard discounts, payment plans.

Referral rewards, loyalty points

-Easy to buy: delivery, available in convenient locations,

-Risk free to buy: refund policies, warranties

-Also to include clear instructions of how to use product and its various features 


\subsection{Development of assumptions}

This section summarises some of the key assumptions that were developed during the course of the research. In some areas, the developments proved positive for commercialisation, while in others they indicated certain barriers. These points will be covered in section 4.4 .

Table 4.5 : Summary of development of stakeholders assumptions

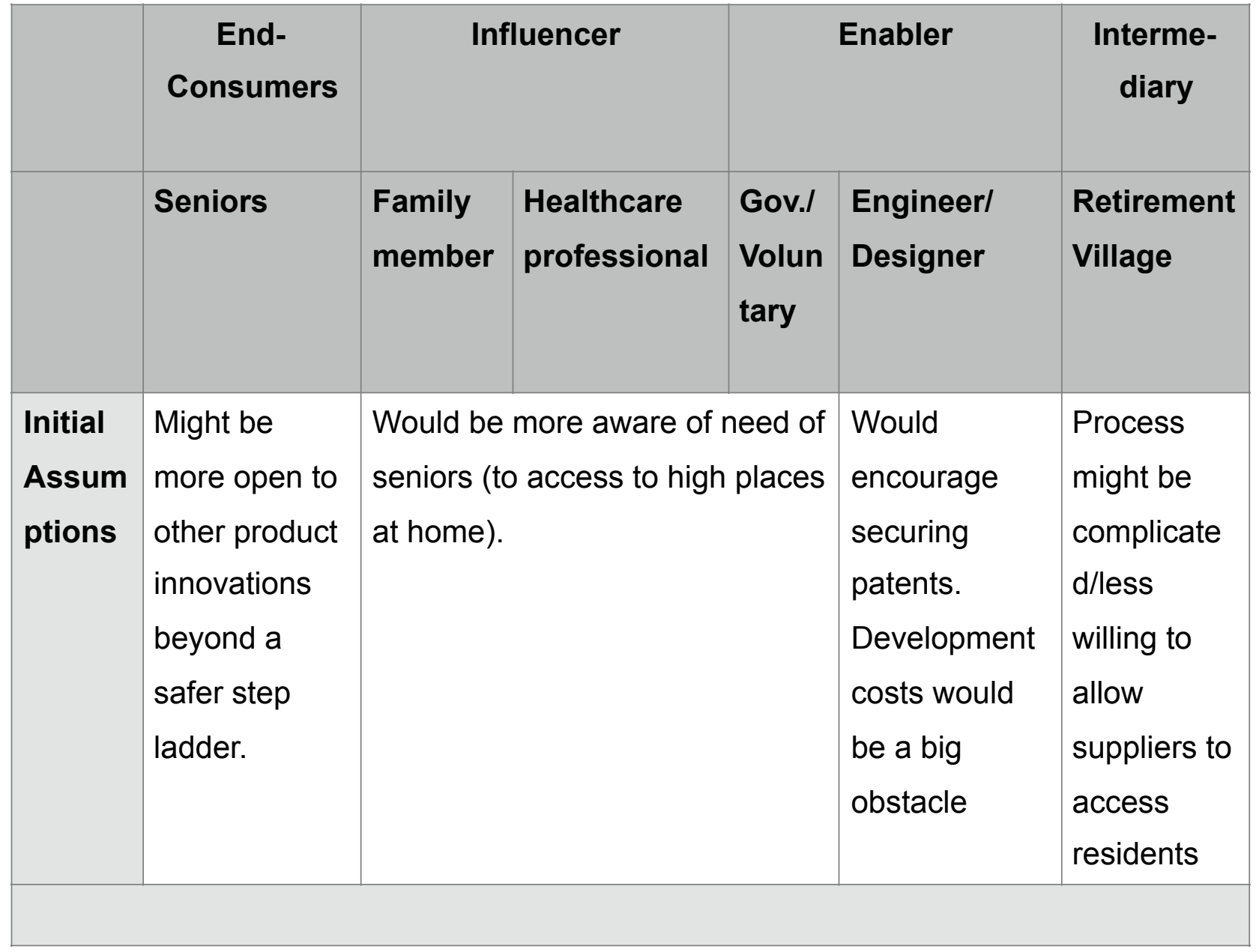




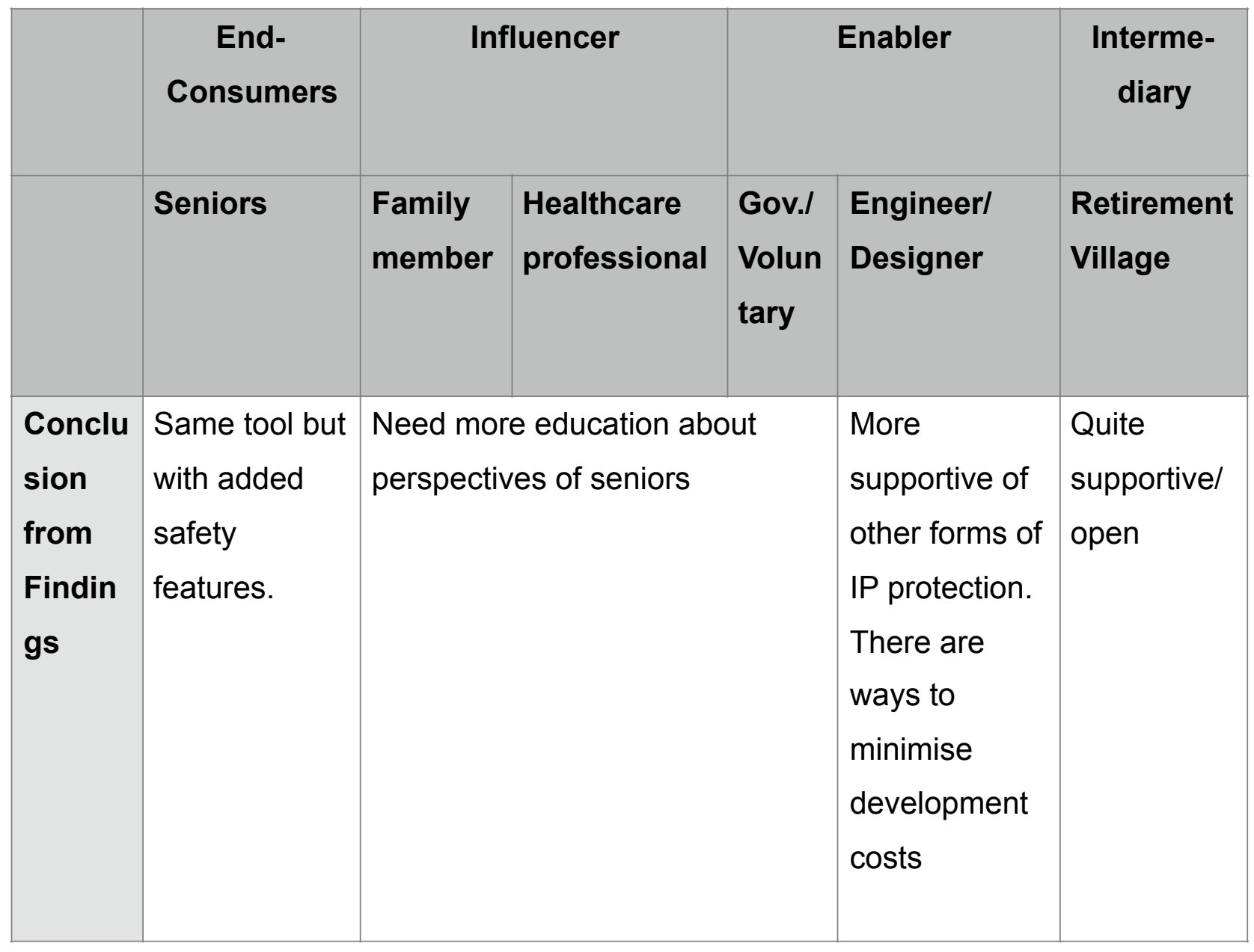

Referring to the above Table 4.5, there were several key assumptions attributed to each stakeholder group. The assumptions were made in relation to factors that would affect commercialisation of the innovation.

\section{End-consumers and preferred product}

For example, I initially assumed seniors would prefer a more automated solution as that would make the task physically less taxing. However, the findings indicated that seniors mainly wanted a better and safer, familiar tool, preferring to do things the same way as they have always done it.

\section{Influencers and awareness of seniors' need}

I had hoped and expected that family members and healthcare professionals would share similar perspectives with seniors on their need to access high places at home. However, it appears the lack of awareness, or perhaps misunderstanding of needs could be a major barrier in getting support from this stakeholder group. 


\section{Enablers and product development}

I assumed government and voluntary organisations (focusing on wellbeing of older people) might take a more proactive role in assisting with grants, but realised it would be more realistic that they would take on a non-financial, supporting role. Their role would be more of an influencer instead of an enabler in this project.

From a product development point of view, I had assumed a major obstacle would be finding a team and the costs involved. However, from the interviews with engineers and designers, it appears that the university could provide some very useful resources that would enable product development. As universities are government-owned, it appears that the government could, thus, still play the role of an enabler.

\section{Intermediary and access to end-consumers}

I was apprehensive about how receptive retirement villages would be to allow access to external suppliers. However, from the findings, both interviewed retirement villages seem relatively supportive and willing to provide access to their residents. 


\subsection{Opportunities and barriers}

The below table 4.6 summarises some of the key opportunities and barriers in the commercialisation of Simple Steps.

Table 4.6 : Summary of Opportunities and Barriers based on stakeholders

\begin{tabular}{|c|c|c|c|c|c|c|}
\hline & \multirow{2}{*}{$\begin{array}{l}\text { End- } \\
\text { Consumers } \\
\text { Seniors }\end{array}$} & \multicolumn{2}{|c|}{ Influencer } & \multicolumn{2}{|c|}{ Enabler } & \multirow{2}{*}{$\begin{array}{l}\text { Intermedia } \\
\text { ry } \\
\text { Retirement } \\
\text { Village }\end{array}$} \\
\hline & & $\begin{array}{l}\text { Family } \\
\text { member }\end{array}$ & $\begin{array}{l}\text { Healthcare } \\
\text { profession } \\
\text { al }\end{array}$ & $\begin{array}{l}\text { Gov.l } \\
\text { Volunta } \\
\text { ry }\end{array}$ & $\begin{array}{l}\text { Engineer/ } \\
\text { Designer }\end{array}$ & \\
\hline $\begin{array}{l}\text { Opportu } \\
\text { nities }\end{array}$ & $\begin{array}{l}\text { Receptive } \\
\text { to Simple } \\
\text { Steps, other } \\
\text { products for } \\
\text { older people }\end{array}$ & \multicolumn{3}{|c|}{$\begin{array}{l}\text { Genuine care and concern for } \\
\text { older people. In their own way, } \\
\text { want the "best" for seniors, even if } \\
\text { they do not realise their definition } \\
\text { of best differs from seniors }\end{array}$} & $\begin{array}{l}\text { Resources } \\
\text { from } \\
\text { university, } \\
\text { access to } \\
\text { talents }\end{array}$ & $\begin{array}{l}\text { Relatively } \\
\text { easy } \\
\text { access }\end{array}$ \\
\hline Barriers & $\begin{array}{l}\text { Marketing, } \\
\text { cost, } \\
\text { quality/ } \\
\text { proven it } \\
\text { works } \\
\text { (implied) }\end{array}$ & \multicolumn{3}{|c|}{$\begin{array}{l}\text { Same as above. Their lack of } \\
\text { understanding or } \\
\text { misunderstanding is a potential } \\
\text { barrier if they cannot be } \\
\text { convinced. }\end{array}$} & $\begin{array}{l}\text { Scalability, } \\
\text { ownership } \\
\text { of IP }\end{array}$ & $\begin{array}{l}\text { Dependent } \\
\text { on how } \\
\text { trustworthy } \\
\text { supplier/ } \\
\text { company is. }\end{array}$ \\
\hline
\end{tabular}

\section{End-consumers}

The biggest opportunity lies in unmet consumer needs. However, findings also revealed seniors tend to be unaware or unreceptive to marketing communications that target "older people", mostly because they dislike how the industry defines older consumers, or may not perceive themselves to belong to this market segment. Hence, this communication barrier needs to be bridged with marketing messages that are more sensitive and appealing to older people. For example, by not focusing on the concept of "older and needing help" but "living longer with independence and dignity". 
Other potential barriers to commercialisation (i.e product purchase) include cost and proven quality effectiveness. These factors are dependent on the product development and production process, which is one of the major "Unknowns" that will be discussed in the next section.

\section{Influencers}

For this stakeholder group, their perspectives could be seen as both opportunities and barriers. They have genuine care and concern for older people, and also believe in enabling Successful Ageing for seniors. However, their definition of what constitutes Successful Ageing is different from that of seniors. This could be an opportunity to educate and raise awareness of the needs of seniors, potentially developing a consumer movement. It might be an opportunity to create a strong brand that is synonymous with good designs for older consumers and becomes a leader in this industry.

\section{Enablers}

Being able to leverage on university resources for product development is a major opportunity in making this project happen. However, beyond development stage, the ease and scalability and commercial viability has to be further evaluated. This is another key Unknown that would be discussed in the next section.

\section{Intermediary and access to end-consumers}

Although there are opportunities to leverage on retirement villages as intermediaries to gain access to seniors, it was also indicated that access would only be given to be reputable and trustworthy suppliers. Hence, a major barrier for me at the time of writing would be the lack of a registered company, a proper brand and a trusted team. Thus, these are the next steps to take.

\subsection{What remains unknown and why}

\section{Product (details on development, manufacturing, scalability and costs):}

As it was not within the scope of this project to develop a theoretical concept into a physical prototype, the key unknowns are specific details of the product. Product concept 
has technically been validated as the technology exists, but there are several manufacturing unknowns, such as whether the product will be as fail-proof as imagined.

Some examples of these unknowns include product design and engineering questions such as: the exact measurements of angles, specific type of materials to be used, how all components would come together, would the folding out and up of the step ladder operate smoothly and seamlessly, how best to design or position handles, how to best to attach wheels and so on. In addition, the accuracy of the proposed sensor can only be assumed for now. The actual software engineering algorithm that would ensure this system works without fail has not been developed, although similar technology exists.

Most importantly, until a physical prototype can be tested, it would be difficult to ascertain manufacturing or operating constraints. Products need to be tested and retested for a period of time before it would be possible to make better predictions. Until the product design is finalised, it would also be challenging to evaluate scalability of production. Consequently, this also implies that actual costs to manufacture this product concept would at best be a very generic estimation based on various assumptions.

\subsection{Comparisons with previous research and similar products}

Although an actual product like Simple Steps does not exist, a range of relevant products with similar design principles and thought processes are applicable to validating its production possibilities. As table 4.7 shows, Simple Steps is an amalgamation of safety features and functions among a range of other products. 
Table 4.7: Summary of similar products that could be applied to Simple Steps'design philosophy

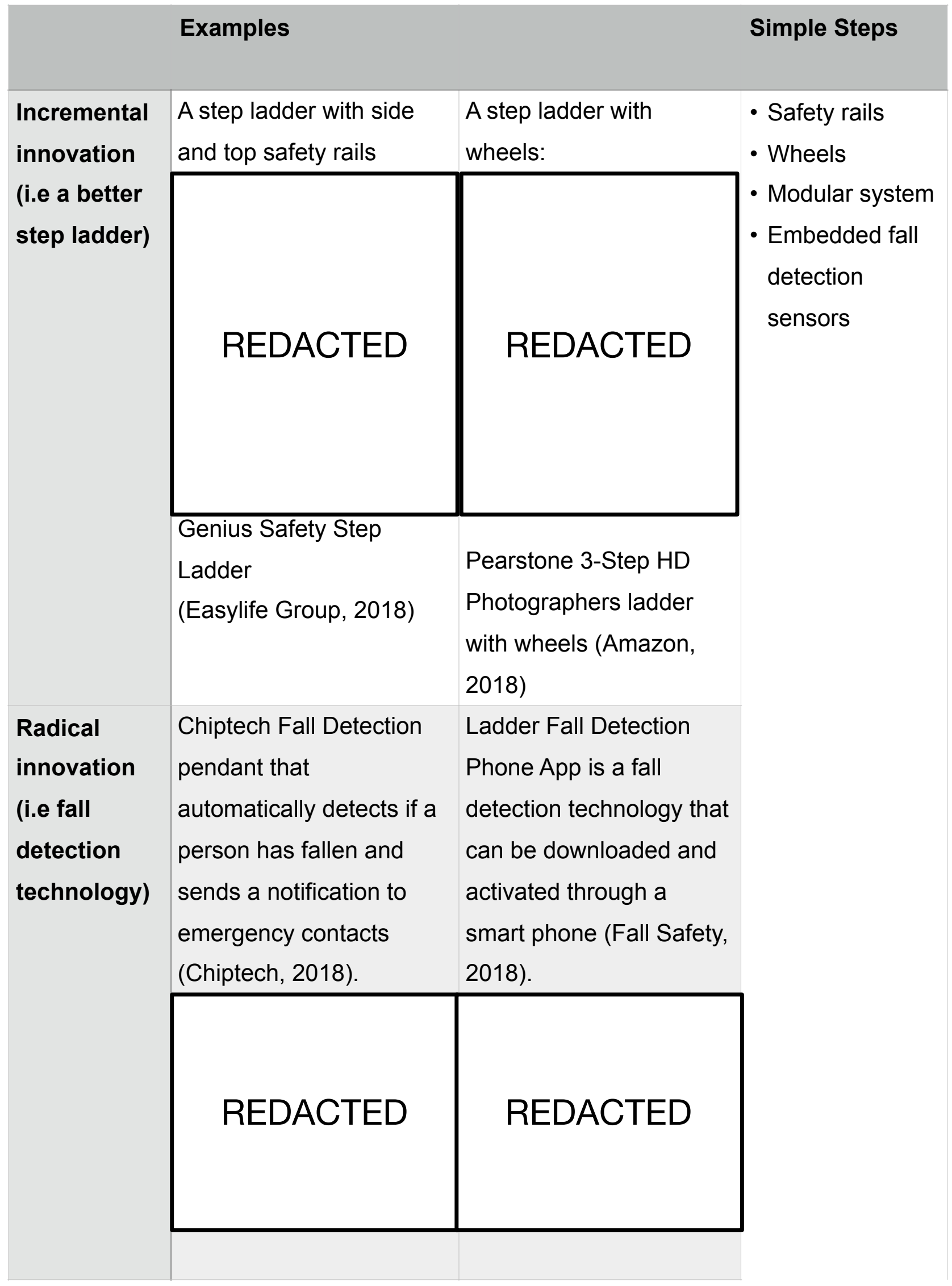




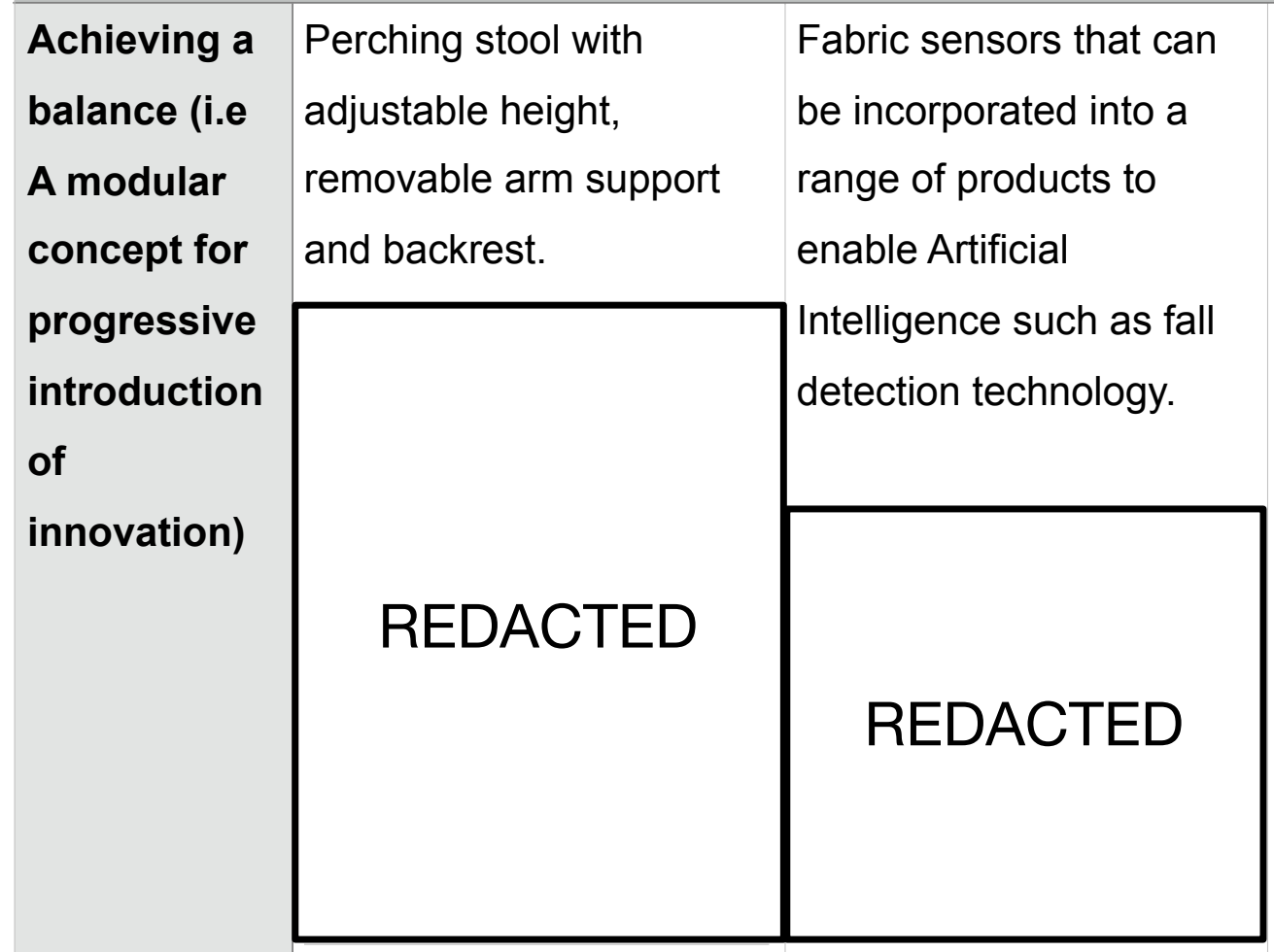

(Manage at Home, 2018)

(Bebop, 2018)

\subsection{Implications beyond this research}

\section{Market}

Firstly, the findings revealed a lack of genuine understanding of seniors by other stakeholders, suggesting there could be a range of neglected consumer needs in the market. Stakeholders such as family members, healthcare professionals and government or voluntary bodies, who are assumed to be campaigning for the rights of older people, tend to believe that taking away the need of engaging in certain tasks equates to safety and wellbeing. However, findings have shown seniors place a stronger importance on independence, and prefer not to be over-protected. In my interviews with seniors, several of them shared their desire for better tools in preserving independence in other aspects of 
their lives, for example in cooking or shopping for groceries. A quote that aptly expresses a common sentiment among seniors is:

- "I wished that people would just come and talk to us... and find out what we want."

This strongly suggests that beyond my specific project of helping seniors access high places in a safer way, many untapped opportunities exists in the consumer market. In particular, to cater to current unmet needs of older people.

\section{Product}

This project could be a firm step towards a new design philosophy movement — one with designing for older consumers in mind. For example, the modular concept of Simple Steps could be applied to other product designs. In the context of Successful Ageing, a modular product could make itself relevant throughout the transitions and phases of growing older, by being incrementally (or radically) safer, depending on the needs of the consumer. As highlighted in the findings, the crucial factor in ensuring acceptance of tools among older people is familiarity of product form, even if functions can be revolutionary (for example, inclusion of sensors). Thus, the implications beyond this project could be a paradigm shift in how tools are being designed for older consumers. As an extension of the above paragraph, another key design principle would be to develop assistive technology for older people that facilitates independence (and continuity of life patterns, if it is desired), instead of dismissing and overriding it. 


\section{Simple Steps}

\section{By HOMFI}
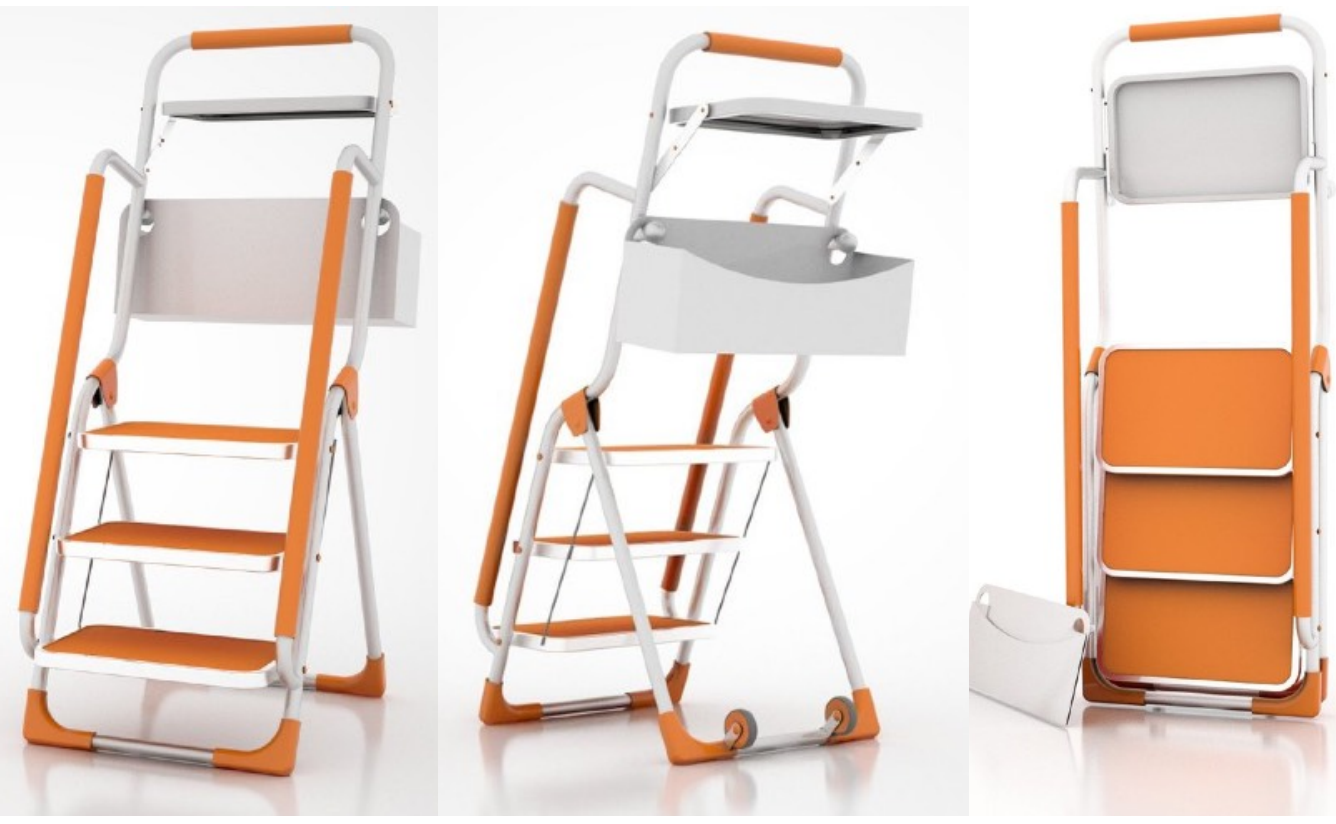

\section{Simple Steps:}

A modular step ladder system which you can customise to suit your needs.

A familiar tool with design innovation to enable, preserve or restore independence.

By HOMFI*:

A brand for older people created with older people.

[*Home Objects made for Independence]

Dear potential project partner/investor,

This proposal will guide you through the inspiration behind Simple Steps by HOMFI, its vision, philosophy and goals. It will provide a summary of the research conducted to date, and present information about the ambitions of the HOMFI concept in the long run, and how the company and brand intends to achieve its social and financial goals.

${ }^{*}$ NOTE: Some sections here may appear repetitive if you have read Part One of this report. 


\section{CHAPTER 5: BUSINESS MODEL DESIGN}

\subsection{Overview of Simple Steps}

Simple Steps is an improved step ladder focused on better safety for older consumers. It is a research-based innovation designed in consultation with a group of Wellington-based older New Zealanders aged between 60 to 90 . Feedback and suggestions made by these seniors were taken into consideration and its development feasibility validated by a pilot group of engineers and designers. The project outcome is a modular step ladder concept where consumers can customise their step ladder by choosing additional product features they desire and/or based on their budget. Simple Steps, in its standard product form, comes with side and top safety handrails and non-slip material on key contact areas such as handrails and steps. It is designed to have enhanced stability when folded out, yet remains relatively lightweight so it is easy to move around. It folds up flat so it does not take up much storage space. The additional features include: attachable and detachable wheels, storage bag, and embedded fall detection sensors (potentially to be available at a later stage).

\subsubsection{Vision}

Simple Steps by HOMFI aims to enable safe access to high spaces at home for seniors so they can continue doing the activities they want to do at home, stay independent and age successfully. HOMFI stands for Home Objects Made for Independence. The vision of HOMFI is to provide affordable innovations that preserve the independence of older people at home for as long as possible. The design philosophy focuses on making products that are easy to use, provides enhanced safety and are aesthetically pleasing. Simple Steps will be the first product to be launched by HOMFI, after which more products based on HOMFI's philosophy will be developed.

\section{As a brand}

HOMFI intends to be a brand known for co-created innovations and having a collaborative culture. It aims to develop innovations with older consumers for older consumers. It values the rights of older people to enjoy and maintain the life they desire but aims to 
make it safer, giving everyone peace of mind. It aims to be a brand that is synonymous with respect for independence in later years and a positive outlook of ageing.

HOMFI aims to develop products which are aesthetically appealing. It wants to enable older people to enjoy safer tools catered to them that look sleek and stylish, instead of looking like a medical or disability tool. A modular product design philosophy will be adopted to enable a product to meet the transitional needs of ageing, as well as to cater to different consumer needs.

\section{As a business model}

It aims to be a cost-conscious business model, leveraging on collaborations and keeping the operations and the team "lean and mean". Being cost-conscious allows savings to be passed on to consumers, thereby achieving the goal of keeping products affordable.

Elaborating on the above mentioned modular product design philosophy, this also makes it easier to roll out products in phases, enabling revenue generation with a minimum viable product $^{3}$, and facilitating multiple revenue streams.

\section{Working towards an ecosystem}

In order to leverage on partnerships and collaborations for cost-savings, HOMFI should work towards becoming an ecosystem for products and services catered to older people. The eventual goal is to create platforms and communities connecting all stakeholders to bring about positive impact for Successful Ageing in society. Section 5.5 elaborates on this point.

Minimum viable product: Product with enough features to satisfy initial group of customers (Osterwalder, 2010). 


\subsubsection{Financial and social goals}

The following table illustrates HOMFI's goals and the intended strategies to achieve them. Table 5.1: Summary of HOMFl's financial and social goals

\begin{tabular}{|l|l|l|}
\hline Goals & What & Ways to achieve goals \\
\hline Financial & $\begin{array}{l}\text { Be a profitable company } \\
\text { within 2 years (breakeven by } \\
\text { end of 1st year). }\end{array}$ & $\begin{array}{l}\text { Minimise cost, increase revenue. } \\
\text { Maximise collaborations, engage in co- } \\
\text { optition* and/or explore joint ventures* } \\
\text { that do not require major capital } \\
\text { Social }\end{array}$ \\
$\begin{array}{ll}\text { investments. } \\
\text { Be a company that creates } \\
\text { a positive impact on society, } \\
\text { in particular in relation to } \\
\text { enabling and ensuring } \\
\text { dignity and wellbeing of } \\
\text { older consumers. }\end{array}$ & $\begin{array}{l}\text { Ensure team and partners shares similar } \\
\text { brand culture. }\end{array}$ \\
\hline
\end{tabular}

Specific goals for Simple Steps (staggered stages in product launch to meet anticipated financial constraints)

1. Launch of Simple Steps (standard version)

2. Using revenue from the first sales of Simple Steps, invest in the development/ refinement of the additional product features (e.g wheels, fall detection sensor). *Potentially, the sensor technology might take a longer development time than the wheels. If that happens, wheels could go into market launch first.

3. Launch Simple Step with full range of additional product features.

4. Develop overseas sales network. 


\subsection{Assumptions that were tested}

Several key assumptions relating to the market, product and business model opportunities were tested as part of the research. Firstly, the crux of this project focused on testing the assumption that there is a need for older consumers to access high places at home independently in a safer way than what current tools offer. The research findings strongly validated this need (Refer to Chapter 3 ).

Secondly, it was assumed that other influential stakeholders such as family members, healthcare professionals and organisations that represent older people, would share the same sentiment on the issue. Findings revealed lack of understanding of this need. However, it also showed that other stakeholders have a genuine respect of seniors' need for independence.

Thirdly, it was assumed that government and/or non-government organisations might provide resources to aid the development of product innovation and/or facilitate the creation of a business model. This was partially validated. Some government resources exist for innovation development, but the major resource these organisations can offer would be the access to a network of relevant experts, talents, and supporting the dissemination of information (to help raise awareness and assist in promotion).

Lastly, assumptions were made that the product concept that arose from consultations with seniors, i.e Simple Steps, can be developed and produced. Engineers and designers interviewed validated this. Existing products and related technologies also point towards a favourable technological and manufacturing climate that will enable the concept of Simple Steps to become reality. 


\subsection{Assessment of Opportunities and Constraints}

The research conducted for this report included an assessment of opportunities and constraints. A summary is shown in table 5.2.

Table 5.2: Summary of opportunities and constraints based on research findings

\begin{tabular}{|c|c|c|}
\hline & Opportunities & Constraints (and implications) \\
\hline $\begin{array}{l}\text { Market } \\
\text { need }\end{array}$ & $\begin{array}{l}\text { Older consumers have } \\
\text { unmet needs with regards } \\
\text { to accessing high places } \\
\text { at home safely and } \\
\text { independently (refer to } \\
\text { Chapter 3). }\end{array}$ & $\begin{array}{l}\text { Consumers tend to be budget conscious so } \\
\text { production costs and other business costs } \\
\text { must be carefully managed. } \\
\text { Some instances of other stakeholders not } \\
\text { understanding or unaware of seniors' needs. } \\
\text { Awareness and education campaigns need } \\
\text { to be implemented. }\end{array}$ \\
\hline $\begin{array}{l}\text { Product } \\
\text { developm } \\
\text { ent }\end{array}$ & $\begin{array}{l}\text { There is potential access } \\
\text { to talent, and availability of } \\
\text { technology providers } \\
\text { through university or } \\
\text { government-backed } \\
\text { organisations, or through } \\
\text { collaborations with } \\
\text { relevant corporations. }\end{array}$ & Establishing a team and/or company \\
\hline $\begin{array}{l}\text { Resource } \\
\text { availability }\end{array}$ & $\begin{array}{l}\text { Apart from the above } \\
\text { point, resources exist in } \\
\text { the form of community- } \\
\text { based promotional } \\
\text { support. Organisations } \\
\text { such as Age Concern and } \\
\text { Super Seniors (by Office } \\
\text { for Seniors) could provide } \\
\text { valuable support in } \\
\text { helping to raise } \\
\text { awareness and exposure } \\
\text { of HOMFl's vision. }\end{array}$ & $\begin{array}{c}\text { structure to connect all relevant } \\
\text { contributors in an integrated system for } \\
\text { efficient and effective collaborations. A } \\
\text { strong brand that is trusted by consumers } \\
\text { and relevant stakeholders must be } \\
\text { created. }\end{array}$ \\
\hline
\end{tabular}




\begin{tabular}{|l|l|}
\hline \multicolumn{1}{|c|}{ Opportunities } & \multicolumn{1}{c}{ Constraints (and implications) } \\
\hline musiness & $\begin{array}{l}\text { There are opportunities to } \\
\text { develop more innovations } \\
\text { catered to older } \\
\text { consumers. There is a } \\
\text { gap in the market for a } \\
\text { business model that co- } \\
\text { creates solutions with } \\
\text { older consumers. Access } \\
\text { to older consumers is } \\
\text { available through } \\
\text { retirement villages. }\end{array}$ \\
\hline
\end{tabular}

\subsection{Business Model Design Recommendations}

Table 5.3: Summary of business model design recommendations

\begin{tabular}{|c|c|c|}
\hline $\begin{array}{l}\text { Business model } \\
\text { design (refer to } \\
\text { page } 77 . \text { ) }\end{array}$ & Ways to achieve & $\begin{array}{l}\text { Evidence this is } \\
\text { achievable in current } \\
\text { business environment }\end{array}$ \\
\hline $\begin{array}{l}\text { Collaborative, co- } \\
\text { create with } \\
\text { consumers }\end{array}$ & $\begin{array}{l}\text { Create interactive communication } \\
\text { channels and multiple points for } \\
\text { feedback, e.g online or in-person. }\end{array}$ & These point towards \\
\hline \multirow[t]{2}{*}{$\begin{array}{l}\text { Design focused, } \\
\text { Cost-conscious }\end{array}$} & $\begin{array}{l}\text { Establish a community, platform } \\
\text { or network of suppliers in key } \\
\text { areas of design, manufacturing } \\
\text { and technology for effective and } \\
\text { efficient innovation and } \\
\text { development. }\end{array}$ & $\begin{array}{l}\text { adopting an eco-system } \\
\text { mentality. Refer to below } \\
\text { section } 5.4 .1 \text { for evidence } \\
\text { on the rise of business } \\
\text { ecosystems. }\end{array}$ \\
\hline & $\begin{array}{l}\text { Leverage on collaborative } \\
\text { partnerships with suppliers, } \\
\text { retailers and distributors. }\end{array}$ & \\
\hline
\end{tabular}




\section{REDACTED}

\subsubsection{Rise of business ecosystems}

\section{Rise of communication technologies}

The world has grown increasingly connected and interlinked through the rise of communication technologies. With the growth of internet and social media, the gap between consumers, company and other stakeholders have greatly minimised. Feedback can be easily collected through these channels and consumers have the opportunities to co-create solutions with companies. At the same time, information can be rapidly disseminated - i.e "going viral". This has become a promotional strategy that many brands try to achieve as it has potential for tremendous exposure at little cost.

\section{Rise of collaborations and the sharing economy}

Accessibility of communication and information has also enabled collaborations and partnerships across industries to be established more easily. Business ecosystem are essentially business platforms and/or communities which "enable and encourage the participants of a diverse range of (large and small) organisations, and often individuals" to come together to "create, scale, and serve markets beyond the capabilities of any single organisation" (Kelly, 2015). Collaborations have also facilitated the "sharing economy" 
where "platform businesses have established entirely new ecosystems that enable vast numbers of participants to share access to their previously idle or under-utilised assets" (Kramer \& Pfitzer, 2016). The concept of co-working offices is a good example of a sharing economy that HOMFI could utilise to save on operating costs.

\section{Rise of social impact through business ecosystems}

Participants of a business ecosystems, including consumers, are often "bonded by some combination of shared interests, purpose, and values" (Kelly, 2015). This benefits the sustainability of an ecosystem as stakeholders share a commitment to a cause, and would likely value a long-term relationship with the business and other participants.

\subsection{Creating an eco-system to achieve HOMFl's vision and goals}

\section{Strategy governed by Vision}

For the purpose of this report, I define the critical success factor of a business model as catering to the consumer need, producing quality and affordable products and being financially prudent as a company ( $\mathrm{Ng} \& \mathrm{Kee}, 2017)$. In order to ensure commercial viability, it is typically dependent on minimising costs for maximum returns. However, HOMFI is a business model that aims to not only be profitable, but to provide social value, particularly for older consumers. It envisions itself as a "Socially Responsible Company", which I define as a company that contributes to the greater good of the community, by advocating the needs of our target consumers, older people. As such, one key point of differentiation and value proposition of the HOMFI business model is to focus on the cocreation of products and innovation with its customers.

As revealed from the research findings, there is currently a demand in the market among older consumers for safer home tools that are not yet available. As an extension from the Business Model Canvas analysis, HOMFI wants to create a long-term, value-based relationship with customers, focused on catering to their needs. This could be facilitated by establishing good customer feedback systems through creating a strong brand community.

From the findings, customers have indicated a strong preference for physical shops to test the product i.e Simple Steps before purchase, and that Bunnings or Mitre 10 were the first 
places that came to mind when they want to shop for a step ladder. In view of that, it is clear that Simple Steps has to have physical presence and should not rely on an online business model. However, a major constraint in delivering on that is the cost to set up retail stores in prominent and easy to access locations. The following sections suggest some recommendations on how to optimise operating costs.

\section{Business ecosystems to optimise operating costs}

Business ecosystems essentially evolve from existing business models. They succeed by attempting to replicate a business model's strengths while minimising weakness by innovating business processes. In the context of HOMFI, I evaluate two traditional business models in the homeware industry. One is a vertically integrated manufacturerretailer business model represented by international home furnishing brand, Ikea. The other is a distributor business model, represented by home tools chain-store Bunnings and Mitre 10.

The recommended business model for HOMFI would be a combination of a vertically integrated manufacturer and retailer, yet without full ownership of manufacturing facilities and retail operations. With reference to the table below, HOMFI would ideally be a cross between the business model of IKEA and Bunnings or Mitre10, but with much lesser asset liabilities (i.e ownership of manufacturing facilities and physical stores). It could reduce the cost of manufacturing by outsourcing production to Original Equipment Manufacturers, or through a supplier partnership, but to retain design control and distribution and marketing rights. 
Table 5.4: Evaluation of the strengths and weaknesses of existing business models

\begin{tabular}{|c|c|c|c|}
\hline Company & Business Model & Strength to emulate & Weaknesses to eliminate \\
\hline Ikea & $\begin{array}{l}\text { Vertical } \\
\text { integrated home } \\
\text { furnishing store, } \\
\text { which is } \\
\text { designer, } \\
\text { manufacturer, } \\
\text { retailer and } \\
\text { franchiser. }\end{array}$ & $\begin{array}{l}\text { A very strong } \\
\text { international brand, } \\
\text { which differentiates } \\
\text { itself with the vision to } \\
\text { "offer a wide range of } \\
\text { well-designed, } \\
\text { functional home } \\
\text { furnishing products at } \\
\text { prices so low that as } \\
\text { many people as } \\
\text { possible will be able to } \\
\text { afford them" (Ikea, } \\
2018 \text { ) }\end{array}$ & $\begin{array}{l}\text { As a company that owns its } \\
\text { supply chain, it has massive } \\
\text { asset liabilities. In the } \\
\text { countries the brand is } \\
\text { present in, it typically only } \\
\text { has one or a few mega } \\
\text { stores, as opposed to being } \\
\text { available in many locations. }\end{array}$ \\
\hline Bunnings & $\begin{array}{l}\text { Hardware chain } \\
\text { store, focused on } \\
\text { a being a } \\
\text { distributor. }\end{array}$ & $\begin{array}{l}\text { Extensive physical } \\
\text { presence in the New } \\
\text { Zealand market and has } \\
\text { an established brand } \\
\text { reputation for affordable } \\
\text { home tools. }\end{array}$ & $\begin{array}{l}\text { Similar to lkea, the } \\
\text { operation costs to maintain } \\
\text { its distribution networks are } \\
\text { very high. Unlike Ikea who } \\
\text { has strong control over } \\
\text { product designs, distributors } \\
\text { do not have much control } \\
\text { over the design process. }\end{array}$ \\
\hline Mitre 10 & $\begin{array}{l}\text { Similar to } \\
\text { Bunnings, but } \\
\text { operates as a co- } \\
\text { operative. }\end{array}$ & $\begin{array}{l}\text { The social value of a } \\
\text { co-operative is similar to } \\
\text { the vision for HOMFI. }\end{array}$ & Similar to Bunnings. \\
\hline
\end{tabular}

\section{Reduce manufacturing costs, establish supplier networks}

Citing the example of Simple Steps, this business model can be achieved by having it as a product conceptualised and designed by HOMFI, but manufactured by an external contracted manufacturer. In the New Zealand context, Ullrich is a ladder manufacturer 
which could potentially be a supplier. The retail and marketing rights would remain with HOMFI. This would enable HOMFI to operate on less financial outlays.

At the product development stage, it would potentially be feasible to work with the engineering and/or design faculty of a university or with innovation labs such as Callaghan Innovation. As a business model, HOMFI would be a coordinating platform between all suppliers. HOMFI should work towards establishing a community, platform or network of suppliers in key areas of design, manufacturing and technology.

\section{Innovative distribution partnerships}

The other major financial outlay is the operational costs of having physical stores. Shop rental and staff employment would require significant financial investments. In order to reduce such costs, it would be recommended for HOMFI to, as an initial step, seek strategic retail partnerships and collaborations and offer Simple Steps to partner retailers to achieve product presence in physical stores. As such, HOMFI would be able to save on rental costs of a store, as well as, all other associated costs such as staff, electricity and payment system. At the same time, HOMFI should endeavour to establish its own lowcost showroom space that is relatively accessible to the public as a way to strengthen its brand image. For example, renting an affordable gallery space to display Simple Steps could be an option. Alternatively, renting a private suite in a co-working office city location, where customers can make an appointment to view and test the product, could also be an option. Section 6.8 further elaborates on the distribution strategy.

\section{Utilising shared resources, focus on creating a strong brand community to encourage word-of-mouth promotion}

As mentioned earlier, a co-working office is a good way to minimise business costs. To save on marketing and promotion costs, HOMFI should focus on generating word-ofmouth among the community. The spread of information could be boosted by going through organisations such as Age Concern, Super Seniors, through retirement villages and SuperGold Card programme. Section 6.7 elaborates on creating a strong brand.

\section{To summarise the business model design recommendation:}

To work towards a business ecosystem, it starts with being a hybrid of the existing business model of: A vertically integrated business, such as IKEA, a retail chain, such as Bunnings, and the concept of a co-operative, such as Mitre 10. The key idea is to 
establish strategic partnerships to reduce need for financial resources, while at the same maximising impact in terms of being available and accessible to customers, and delivering on HOMFI's vision and goals. 


\subsection{Target consumers}

\section{Older consumers who desire independence - but what does it mean?}

The main target market of Simple Steps by HOMFI is older consumers who value independence, desire continuity of life patterns, and feel a sense of belonging to the "Do it yourself Kiwi Culture". Specifically, the project was focused on older adults who have needs of accessing high places at home.

To define the term "older" is however not straightforward as different organisations have their own perception of when a person can be considered senior. For example, the Super Seniors defines older people as "65 and above" (Super Seniors, 2018) while Grey Power represents anyone over the age of 50 (Grey Power, 2018).

This research included older participants from the age of 60 to 90 , who are living independently in a range of dwellings including within retirement villages and in the community. Views were collected from older adults who lived in both apartments or houses.

The key takeaway of the project findings is to recognise that there are specific needs of older consumers at different age bands, as well as different lifestyle patterns which would all constitute desiring independence. A 60 year old's needs would likely be significantly different from that of a 90 year old. Findings suggest that those under the age of 70 would most likely be living in a house in the community, while those over 80 tend to be living in an apartment and have a higher chance of being part of a retirement village complex, based on this project's sample population. The living situation would also affect the type of needs relating to accessing high places. For example, those in a house with a garden would likely have gardening needs, while those in apartments might have more need to access high shelves because of this is a way to maximise limited space.

In the current society, a 60 year old or a 90 year old may both be considered "older adults" in the most generic terms, resulting in specific needs and wants of older people at different stages of life being neglected. Such distinction must be acknowledged by society and 
industries so that products catered to sub-segments of the generic "older consumer" can be developed. Hence, solutions need to be adaptable and anticipate changing desires with time by constantly seeking feedback from consumers. The availability of Simple Steps as a modular concept and HOMFI's goal to be a brand that co-creates solutions with consumers attempts to address and anticipate these differences in consumer needs.

\section{Secondary target market}

Apart from older consumers, a secondary target market would be people who care for seniors, such as family members. Although I identified some support in this segment through the research, the findings suggests that the biggest market remains with seniors themselves. The research results revealed that most older people strongly prefer making their own purchase decisions, again strengthening the case for respecting their need for independence. However, that is not to say that the secondary market segment should be ignored, rather in the prioritisation of resources, the immediate marketing strategy would target seniors.

Moving beyond the consumer market, there could be potential to target organisations and businesses with step ladder needs. For example, specific to this project, Simple Steps could be sold to retirement villages either for the usage of their own staff (such as an onsite tradesman) or to be available for their residents to lend.

\subsection{Where product adds value - why do consumers need Simple Steps?}

In its simplest sense, Simple Steps is a better, safer step ladder. The safety features of Simple Steps, in particular the addition of side and top handles, as minor an innovation as it might appear, creates great value for older consumers by enabling, preserving and restoring (lost) independence (refer to page 41). Current tools in the market do not offer enough safety features to provide older people with the confidence that they can continue to live independently. Referring to Chapter 3, there is strong evidence to show that older people greatly value their independence, ascribe emotional attachments and meanings to home tasks and desire a continuity of life patterns for as long as possible. Therefore, the greatest value of Simple Steps by HOMFI would be the facilitation of both safety and independence, thereby contributing to an older person's dignity, self-worth and allowing 
them to age successfully. Consequently, this would allow people who care about older adults such as family members, to have peace of mind.

In addition, the modular concept of Simple Steps provides autonomy in enabling choice and flexibility. This concept is not widely available in current step ladders in the market. By allowing consumers to select additional product attributes at additional costs, it gives consumers the ability to pay the minimum price if those features are unnecessary. This would help older consumers save costs, which based on research findings, is a key factor in their purchase decisions. At the same time, it also offers the choice to "upgrade" the step ladder in future, if needs change with time. Thus, this enables Simple Steps to "age successfully" with its consumer by meeting their needs at different times of their lives, reflecting the long-term customer relationship the HOMFI brand aims to achieve.

\subsection{Current solutions in market}

Based on research findings, Simple Steps was developed because the most common solution that older consumers are using to access high places at home is a step ladder (refer to Chapter 3 ). Although there are other alternatives such as using hand grabbers, tailor-made cabinets with lower shelves and hiring tradesmen, the step ladder appears to be the most widely used and desired tool. Thus, the competitor analysis in section 6.5 will focus on comparing Simple Steps with other step ladders in the New Zealand market.

\subsection{Market's reaction to Simple Steps}

\section{General appeal and how it compares with competition}

General sentiments from all research participants towards Simple Steps are positive. According to the final online survey results, favourable responses to key aspects of Simple Steps were recorded (refer to Chapter 3 ). These aspects refer to the product's appeal, perceived safety and ease of use, as well as being seen as better than what is currently available in the market. The findings are encouraging for the further development of Simple Steps and related technology. 


\section{Receptiveness to the modular concept}

Based on research findings, the majority of participants selected to include at least one of the three given additional product features (wheels, storage bag, fall detection sensor) (refer to Chapter 3). There was an option to choose "none" (i.e to not include additional product attributes), which was selected by one senior. The most popular option was wheels, followed by an embedded fall detection sensor device, then storage bag. The varying popularity levels of these different product attributes is further validation of a modular product concept. From a consumer perspective, customers are given the autonomy to customise their product. From a business and production point of view, it allows the company to be more reactive to consumer demands. It enables HOMFI to be more nimble in introducing new and desirable additional product attributes, while less popular product attributes could be more easily removed from the production line, without major disruptions to the manufacturing process.

\section{Price sensitivity}

The research placed a hypothetical price of Simple Steps at $\$ 100$ and $\$ 150$ to compare how likely consumers would buy the product at different price points (refer to Chapter 3). Evidence suggests that a competitive price is a relatively important consideration in the purchase decision of Simple Steps. However, a premium for better quality and additional options appears to be acceptable to some. Simple Steps would need to achieve a good balance of price and quality. This relates to positioning strategies which will be discussed in Section 6.7.

\section{Willingness to recommend the product to others}

Most participants indicated they would recommend Simple Steps to others. This is very positive news and further validation that Simple Steps is an attractive product. It also suggests that HOMFI would be able to leverage on word-of-mouth marketing to promote Simple Steps. This is the most cost-effective marketing strategy to generate awareness and interest of a product. 


\subsection{Barriers to change}

\section{Need and cost to upgrade to a better step ladder.}

For those who already possess a step ladder, the biggest obstacle would be whether Simple Steps offers enough added value at an attractive enough price for consumers to make the switch. Although it does appear that Simple Steps possesses competitive advantage, at the current point of writing, price is an unknown. However, based on research findings, there is a clear indication that Simple Steps should be priced competitively. This suggests adopting a target costing strategy in the production process which would be discussed in Chapter 7 .

\section{Accessibility to test and buy}

Being able to physically test the product before purchase ranked highly on consumer's key decision making factor (refer to Chapter 3). Availability of the product in convenient locations would thus affect the likelihood of purchase. Therefore, it is crucial to enable Simple Steps to be easily accessible in a range of locations. This will be discussed in section 6.8 which elaborates on distribution strategies.

\section{Negative marketing messages}

Stereotypical, patronising and manipulative marketing messages (advertisements) were mentioned as undesirable and barriers to acceptance (refer to Chapter 3). It is therefore important that in all marketing communications, Simple Steps by HOMFI does not overemphasis "older" being synonymous with frail or weak. Rather, the message should be positive. Essentially, the image of an older person should be one that is strong as opposed to weak, and assistive tools should be seen as facilitating independence instead of assisting the "needy". This will be discussed in the positioning strategies covered under section 6.7 .

\section{Confidence to operate the tool easily}

A key takeaway from the findings was how older consumers value continuity of life patterns, which translates into the need for familiar tools. The adoption of new equipment or technology by older people is heavily dependent on how easy it can be used and operated with minimal learning. Otherwise, older consumers might get frustrated and give up on utilising devices that can enhance safety. This highlights the need for intuitive 
product design that takes little learning for one to be proficient in handling. In the context of Simple Steps, it must be ensured that, for example, the product is easy to fold out and up, wheels attach and detach easily, and the fall detection sensor is activated with simple navigation. To further enhance confidence in tool operation, good and clear instruction guides are also important.

\subsection{Competitor Analysis}

\section{Direct competitors}

In the context of Simple Steps, direct competitors are other step ladders available to purchase in New Zealand. Figure 6.1 below presents the test results of a step ladder review conducted by Consumer NZ, which reviewed 16 step ladders in the New Zealand market. The step ladders were subjected to safety tests listed in the AUS:NZ ladder standards. Most step ladders sold in retailers do not adhere to AUS:NZ ladder standards as it not a mandatory requirement. The findings by Consumer NZ stated that the only stepladder that passed all safety tests does not include a grab rail, which is an important safety feature. This further validates the importance of the safety handles that Simple Steps has.

Figure 6.1: Screenshot of step ladder review by Consumer NZ

\section{REDACTED}


Adherence to AUS:NZ ladder standards topped the list in older consumers' key decisionmaking factor. Hence, further competitor research was conducted on step ladders that are compliant with this safety standard, one from Australian brand, Bailey, and the other from New Zealand ladder manufacturer, Ullrich.

Figure 6.2: Bailey step ladder

\section{REDACTED}

Figure 6.3: Ullrich step ladder

\section{REDACTED}

Both Bailey and Ullrich step ladders emphasise safety, durability and their compliances with AUS:NZ standards as key selling points. Features which Simple Steps also highlight. Based on product information listed above for the two step ladders, it appears that the 
Bailey step ladder would be a stronger competitor of Simple Steps, compared with Ullrich. However, neither step ladder offers side handles, nor offers the option for a fall detection sensor, product features which have demand among older consumers. Simple Steps also offers more specific safety features for older consumers such as wide steps and non slip material on handles and steps. Overall, Simple Steps also wins on visual appeal and looks easier to use.

It must be noted that price information on this two step ladders was not available. Hence, a price review could not be conducted. There was also no specific information on the location availability of these two products. However, Bailey and Ullrich ladders are typically not sold through distributors such as Bunnings and Mitre 10, which are places older consumers have consistently mentioned they go to source a step ladder. Instead, their focus is on catering to commercial clients such as businesses in construction industry. This suggests an opportunity for Simple Steps to engage in co-optition ${ }^{4}$ with these brands, as they do not necessarily compete with Simple Steps for the same group of consumers. Simple Steps could potentially collaborate with the above ladder manufacturers on a project-specific partnership, such as a joint venture ${ }^{5}$. This in in line with HOMFI's aim to minimise product development costs, and to work towards an ecosystem business model, as indicated in Chapter 5.

It should again be highlighted that although this project focused on step ladder innovations, the HOMFI concept does not endeavour to be a step ladder company, but a brand that eventually offers a range of safer home tools for older people. This is also how Simple Steps aims to further strengthen its competitive advantage through brand positioning.

\footnotetext{
4 Co-opetition: Collaborating with organisations traditionally considered as competitors (Angwin, Cummings, Smith, 2011).

5 Joint venture: A business partnership between two or more distinct entities where resources are invested for the purpose of a specific project (Angwin, Cummings, Smith, 2011).
} 


\subsection{Positioning}

The below table 6.1 provides an overview of how Simple Steps intends to position itself in the market, and the corresponding implementation strategies.

Table 6.1: Brand positioning of HOMFI (Simple Steps)

\begin{tabular}{|c|c|c|}
\hline $\begin{array}{l}\text { Brand position } \\
\text { (image) }\end{array}$ & Elaboration & Ways to implement \\
\hline $\begin{array}{l}\text { Quality product } \\
\text { that meets } \\
\text { stringent safety } \\
\text { standards }\end{array}$ & $\begin{array}{l}\text { As per my research findings, } \\
\text { consumers place very high } \\
\text { importance on the criterion that } \\
\text { Simple Steps adheres to AUS;NZ } \\
\text { standards. It is intended that } \\
\text { Simple Steps would be designed } \\
\text { to meet those standards, or } \\
\text { equivalent international } \\
\text { standards. Thus, the brand } \\
\text { position of Simple Steps should } \\
\text { emphasis on its high safety and } \\
\text { quality standards. }\end{array}$ & $\begin{array}{l}\text { Testing certifications should } \\
\text { be prominently displayed on } \\
\text { all marketing communication } \\
\text { and collaterals of Simple } \\
\text { Steps. This includes } \\
\text { website information, any } \\
\text { flyers, brochures, and on the } \\
\text { physical product packaging. }\end{array}$ \\
\hline $\begin{array}{l}\text { Affordable price } \\
\text { (with a possible } \\
\text { slight premium) but } \\
\text { value for money }\end{array}$ & $\begin{array}{l}\text { HOMFI intends to be a socially } \\
\text { responsible company and thus, } \\
\text { should cater to the needs of the } \\
\text { masses. Therefore, the brand } \\
\text { should not be seen as exclusive } \\
\text { or only catering to a select group } \\
\text { of older consumers. Although } \\
\text { quality would be emphasised in } \\
\text { the brand image, the price } \\
\text { positioning should be affordable. }\end{array}$ & $\begin{array}{l}\text { This has to be implemented } \\
\text { through the manufacturing } \\
\text { process, with further } \\
\text { investigations required to } \\
\text { figure out exact costings } \\
\text { details. Ideally, a } \\
\text { collaboration with a } \\
\text { manufacturer can be } \\
\text { established (as mentioned } \\
\text { in the previous section) }\end{array}$ \\
\hline
\end{tabular}




\begin{tabular}{|c|c|c|}
\hline $\begin{array}{l}\text { Brand position } \\
\text { (image) }\end{array}$ & Elaboration & Ways to implement \\
\hline $\begin{array}{l}\text { Created with older } \\
\text { consumers, for } \\
\text { older consumers } \\
\text { with a positive } \\
\text { message on ageing } \\
\text { (ie. focusing on } \\
\text { conveying } \\
\text { "possibilities and } \\
\text { safety", instead of } \\
\text { "limitations and } \\
\text { danger”) }\end{array}$ & $\begin{array}{l}\text { One of the key findings was that } \\
\text { older people find the current } \\
\text { marketing messages targeted at } \\
\text { seniors "stereotypical" and often } \\
\text { "manipulative". It is mostly } \\
\text { viewed in a negative manner for } \\
\text { those who have been exposed to } \\
\text { marketing communications for } \\
\text { older consumers. The negative } \\
\text { perceptions of products for } \\
\text { seniors has to be overcome. } \\
\text { Otherwise, it runs the risk of } \\
\text { having the marketing message } \\
\text { completely ignored by target } \\
\text { consumers. }\end{array}$ & $\begin{array}{l}\text { This has to communicated } \\
\text { through an integrated } \\
\text { marketing campaign where } \\
\text { a consistent message is } \\
\text { conveyed across all } \\
\text { promotional channels. For } \\
\text { example, storytelling } \\
\text { through videos, brochures, } \\
\text { public relation events, } \\
\text { education and promotional } \\
\text { workshops etc. (refer to } \\
\text { figure } 6.4 \text { below) }\end{array}$ \\
\hline $\begin{array}{l}\text { Enhanced safety in } \\
\text { familiar tools to } \\
\text { enable/restore/ } \\
\text { preserve } \\
\text { independence }\end{array}$ & $\begin{array}{l}\text { Independence is important for } \\
\text { older people, and they want to } \\
\text { maintain independence in a } \\
\text { familiar way, through the use of } \\
\text { familiar tools. }\end{array}$ & \multirow[t]{2}{*}{$\begin{array}{l}\text { This has to be implemented } \\
\text { through the design of the } \\
\text { product. It would be part of } \\
\text { the design philosophy and } \\
\text { brand value of HOMFI. } \\
\text { (refer to Figure } 6.4 \text { below) }\end{array}$} \\
\hline $\begin{array}{l}\text { Discreet, } \\
\text { unobtrusive } \\
\text { assistance that } \\
\text { enables continuity } \\
\text { of life patterns (i.e } \\
\text { Successful Ageing) }\end{array}$ & $\begin{array}{l}\text { Findings reveal that familiarity of } \\
\text { tool is key to acceptance of } \\
\text { assistive technology. }\end{array}$ & \\
\hline
\end{tabular}

Examples of positive marketing (given by some of the research participants).

Recent zimmer frame innovation called Nip-Glide by New Zealand innovators might shed some light on the type of marketing message to adopt. 


\section{REDACTED}

\section{Communication strategies for HOMFI (Simple Steps) to adopt}

Nip Glide utilises attractive visuals and portrays older people as active members of society who are enjoying life. This image on the home page of its website shows an independent woman using a red zimmer frame, looking positive, emanating strength and elegance. The colour choice of the zimmer frame - red, further emphasises vibrancy and energy. Overall, the visual portrays the assistive technology (zimmer frame) as a lifestyle tool that will aid in enhancing vitality of life. The image speaks of "successful ageing". These are visual cues that Simple Steps/HOMFI could take note of its marketing campaigns. 


\subsection{Distribution of Simple Steps}

This project investigated the possibility of getting access to seniors through retirement villages, which was validated (refer to Chapter 3 ). This might be one of several distribution strategies to take, although this channel needs further exploration with managers of retirement villages. It may not offer the most extension exposure, but it would potentially be the most cost-effective method that offers direct access to target customers.

Research findings revealed that while one of the key purchase decisions is the ability to physically test the step ladder, the first point of information search is typically conducted through the Internet. Bunnings and Mitre 10 are the most popular places to shop for a step ladder. At the same time, there is general lack of awareness of any place (or brand) that offers safer tools for older people, with the exception of a few who have knowledge of a store called Mobility Centre that sells a range of mobility tools. Hence, the distribution strategy is closely tied to the brand strategy of establishing HOMFI as a brand that creates "safer home tools for older people, co-created with older people".

\section{Key implications for distribution strategies:}

1. Clear, easy-to-find information about Simple Steps/HOMFI must be present online.

2. Enable Simple Steps to be physically available for consumers to test in various locations. Be nimble and establish as much physical presence as possible through strategic partnerships such as participating in events and collaborating with a range of retailers.

3. Utilise both online and in-person strategies to grow brand awareness and exposure, to facilitate product purchase and/or referrals.

Simple Steps aims to generate maximum consumer awareness, exposure and be available in the widest possible options for purchase, while incurring minimal costs. This requires some creativity and unconventional partnerships. The following table 6.2 summarises the distribution plan for Simple Steps by HOMFI. 
Table 6.2: Summary of distribution strategy

\begin{tabular}{|c|c|c|c|}
\hline & $\begin{array}{l}\text { INCREASE } \\
\text { AWARENESS AND } \\
\text { EXPOSURE }\end{array}$ & $\begin{array}{l}\text { ENHANCE } \\
\text { INTEREST/ } \\
\text { DESIRE }\end{array}$ & $\begin{array}{l}\text { ENCOURAGE } \\
\text { ACTION (BUY) }\end{array}$ \\
\hline Channels & $\begin{array}{l}\text { Information about } \\
\text { Simple Steps/HOMFI }\end{array}$ & $\begin{array}{c}\text { To test Simple } \\
\text { Steps }\end{array}$ & $\begin{array}{c}\text { To buy Simple } \\
\text { Steps }\end{array}$ \\
\hline $\begin{array}{l}\text { Online: website, } \\
\text { blogs, e- } \\
\text { newsletters, } \\
\text { Google } \\
\text { Advertisements, } \\
\text { Search Engine } \\
\text { Optimisation (SEO) }\end{array}$ & $\begin{array}{l}\text { Communicate a clear } \\
\text { brand story, detail what } \\
\text { product has to offer with } \\
\text { attractive visuals. } \\
\text { Ensure fonts are easy to } \\
\text { read (not too small), } \\
\text { colours have good } \\
\text { contrast and the website } \\
\text { is easy to navigate. } \\
\text { Encourage information } \\
\text { sharing. }\end{array}$ & $\begin{array}{l}\text { Clear } \\
\text { information } \\
\text { about places to } \\
\text { test and buy } \\
\text { Simple Steps. }\end{array}$ & $\begin{array}{l}\text { Set up an e- } \\
\text { commerce store (on } \\
\text { the HOMFI website) } \\
\text { to enable } \\
\text { consumers who } \\
\text { have already tested } \\
\text { Simple Steps to buy } \\
\text { online (and have it } \\
\text { delivered). }\end{array}$ \\
\hline $\begin{array}{l}\text { Social media: } \\
\text { Facebook, } \\
\text { Instagram, } \\
\text { Youtube }\end{array}$ & $\begin{array}{l}\text { Utilise strong visuals to } \\
\text { convey the HOMFI } \\
\text { brand, create videos that } \\
\text { showcase Simple Step in } \\
\text { use (by seniors) and } \\
\text { clear instructional } \\
\text { information. Encourage } \\
\text { information sharing. }\end{array}$ & \multicolumn{2}{|c|}{$\begin{array}{l}\text { Clear links to HOMFI website to } \\
\text { enable audiences to find out more } \\
\text { details. }\end{array}$} \\
\hline
\end{tabular}




\begin{tabular}{|c|c|c|c|}
\hline & $\begin{array}{c}\text { INCREASE } \\
\text { AWARENESS AND } \\
\text { EXPOSURE }\end{array}$ & $\begin{array}{l}\text { ENHANCE } \\
\text { INTEREST/ } \\
\text { DESIRE }\end{array}$ & $\begin{array}{l}\text { ENCOURAGE } \\
\text { ACTION (BUY) }\end{array}$ \\
\hline Channels & $\begin{array}{l}\text { Information about } \\
\text { Simple Steps/HOMFI }\end{array}$ & $\begin{array}{c}\text { To test Simple } \\
\text { Steps }\end{array}$ & $\begin{array}{c}\text { To buy Simple } \\
\text { Steps }\end{array}$ \\
\hline Retirement villages & $\begin{array}{l}\text { Distribute collaterals } \\
\text { such as flyers and } \\
\text { brochures with brand and } \\
\text { product information. } \\
\text { Seek permission to place } \\
\text { advertisements on } \\
\text { noticeboards or at } \\
\text { reception counter. }\end{array}$ & \multicolumn{2}{|c|}{$\begin{array}{l}\text { Participate in supplier exhibitions } \\
\text { and/or explore whether the HOMFI } \\
\text { could organise demonstration events } \\
\text { on premises. }\end{array}$} \\
\hline $\begin{array}{l}\text { Events (e.g } \\
\text { conferences, trade } \\
\text { fairs, pop-ups, } \\
\text { demonstrations) }\end{array}$ & \multicolumn{3}{|c|}{$\begin{array}{l}\text { Distribute collaterals such as flyers and brochures with brand } \\
\text { and product information. Participant in relevant events or } \\
\text { organise events in partnership with NGOs and/or government } \\
\text { organisations (e.g Age Concern, SuperSeniors, Grey Power etc } \\
\text { to showcase and demonstrate product. }\end{array}$} \\
\hline $\begin{array}{l}\text { Promotion } \\
\text { partners* (e.g } \\
\text { Galleries/ } \\
\text { Bookstores, Hobby } \\
\text { boutiques, } \\
\text { Convenience } \\
\text { stores “diaries") }\end{array}$ & \multicolumn{3}{|c|}{$\begin{array}{l}\text { Explore partnerships with shops where staff members need to } \\
\text { use a step ladder for their own operations. Propose to offer } \\
\text { Simple Steps (either free or subsidised, depending on } \\
\text { negotiations) for the store's own use, with the agreement that at } \\
\text { least one set of Simple Steps would be displayed in a visible } \\
\text { location in store and that consumers can try it. Negotiate to } \\
\text { allow promotional information to be placed at the store for an } \\
\text { advertising fee. }\end{array}$} \\
\hline $\begin{array}{l}\text { Consignment } \\
\text { partners* (e.g } \\
\text { Homeware/ } \\
\text { Furniture stores, } \\
\text { Paint shops) }\end{array}$ & \multicolumn{3}{|c|}{$\begin{array}{l}\text { Explore consignment partnerships with shops that sell products } \\
\text { or services related to home tools and items (i.e a commission } \\
\text { will be paid to them for every sale). Alternatively, explore if they } \\
\text { would be interested in the promotion partnership (above). }\end{array}$} \\
\hline
\end{tabular}




\begin{tabular}{|c|c|c|c|}
\hline & $\begin{array}{l}\text { INCREASE } \\
\text { AWARENESS AND } \\
\text { EXPOSURE }\end{array}$ & $\begin{array}{l}\text { ENHANCE } \\
\text { INTEREST/ } \\
\text { DESIRE }\end{array}$ & $\begin{array}{l}\text { ENCOURAGE } \\
\text { ACTION (BUY) }\end{array}$ \\
\hline Cha & $\begin{array}{l}\text { Information about } \\
\text { Simple Steps/HOMFI }\end{array}$ & $\begin{array}{l}\text { To test Simple } \\
\text { Steps }\end{array}$ & $\begin{array}{c}\text { To buy Simple } \\
\text { Steps }\end{array}$ \\
\hline $\begin{array}{l}\text { Major distributors: } \\
\text { Bunnings, Mitro, } \\
\text { MegaMarts (e.g } \\
\text { Kmart, Warehouse) }\end{array}$ & \multicolumn{3}{|c|}{$\begin{array}{l}\text { A distribution partnership with major chain stores could be } \\
\text { considered (at a later stage). This is not a strategic focus during } \\
\text { the brand building of HOMFI. Although an easy way to establish } \\
\text { physical product presence, distributors typically take a very } \\
\text { substantial portion of project margins, which will affect overall } \\
\text { profitability and sustainability of the company. They also do not } \\
\text { offer strong branding opportunities for HOMFI to differentiate } \\
\text { from other suppliers. Once HOMFI has established itself as a } \\
\text { recognised brand, HOMFI would be in a much stronger position } \\
\text { to negotiate terms with these major distributors. }\end{array}$} \\
\hline
\end{tabular}

It would also be wise for HOMFI to become a SuperGoldCard partner to increase exposure to target consumers. Existing business partners of SuperGold Card could be potential HOMFI collaborators. As shown in Figure 6.5, the benefits of being part of the SuperGold Card programme is self-explanatory. Figure 6.6 further illustrates the added advantage of cross-promotion of SuperGold Card offers on the Super Senior website, increasing consumer awareness of businesses that partner with SuperGold Card.

Figure 6.5 Screenshot of SuperGold Card programme for businesses 


\section{REDACTED}

\section{Further elaboration of distribution strategy:}

An integrated strategy where distribution of information (of brand and product) should be well aligned with distribution of Simple Steps. To create brand and product interest by moving away from the conventional idea that step ladders should only be available at home tool shops. Enable Simple Steps to be more accessible and gain more exposure among the public and generate word of mouth. Utilise online and social media channels to reach out to family members and other stakeholders, who would likely convey information to seniors. Engage in strategic partnerships with organisations focused on older people to further increase message exposure. Involve older consumers in the development of marketing content e.g get older consumers to be part of testimonial videos. This will enhance credibility and also create a higher chance of the message being shared within the community. Simple Steps should be offered through retail partners where foot-traffic is high and in places familiar to and/or frequented by older consumers. 


\section{CHAPTER 7: PRODUCT VALIDATION AND DEVELOPMENT}

\subsection{Product features needed and why}

Figure 7.1 : Simple Steps prototype (now and future)

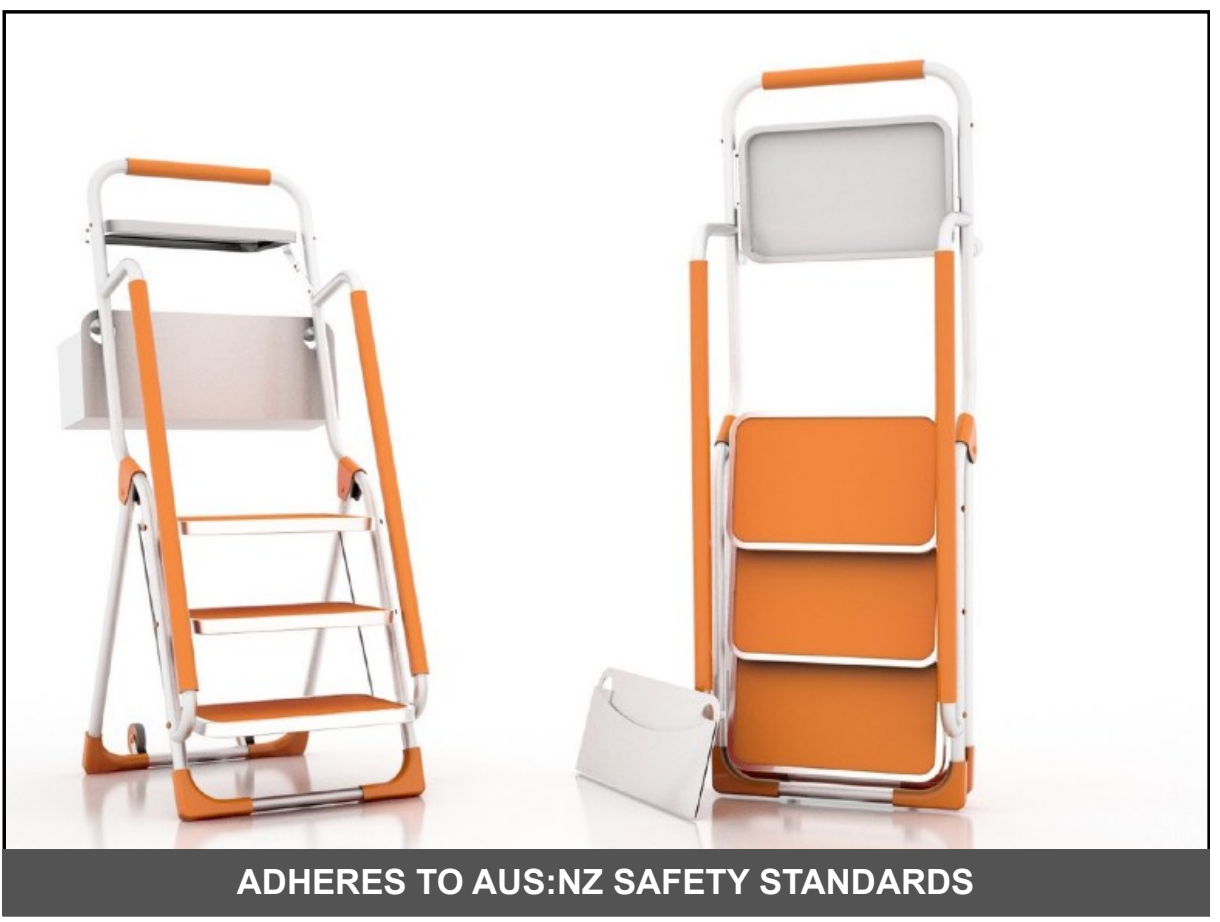

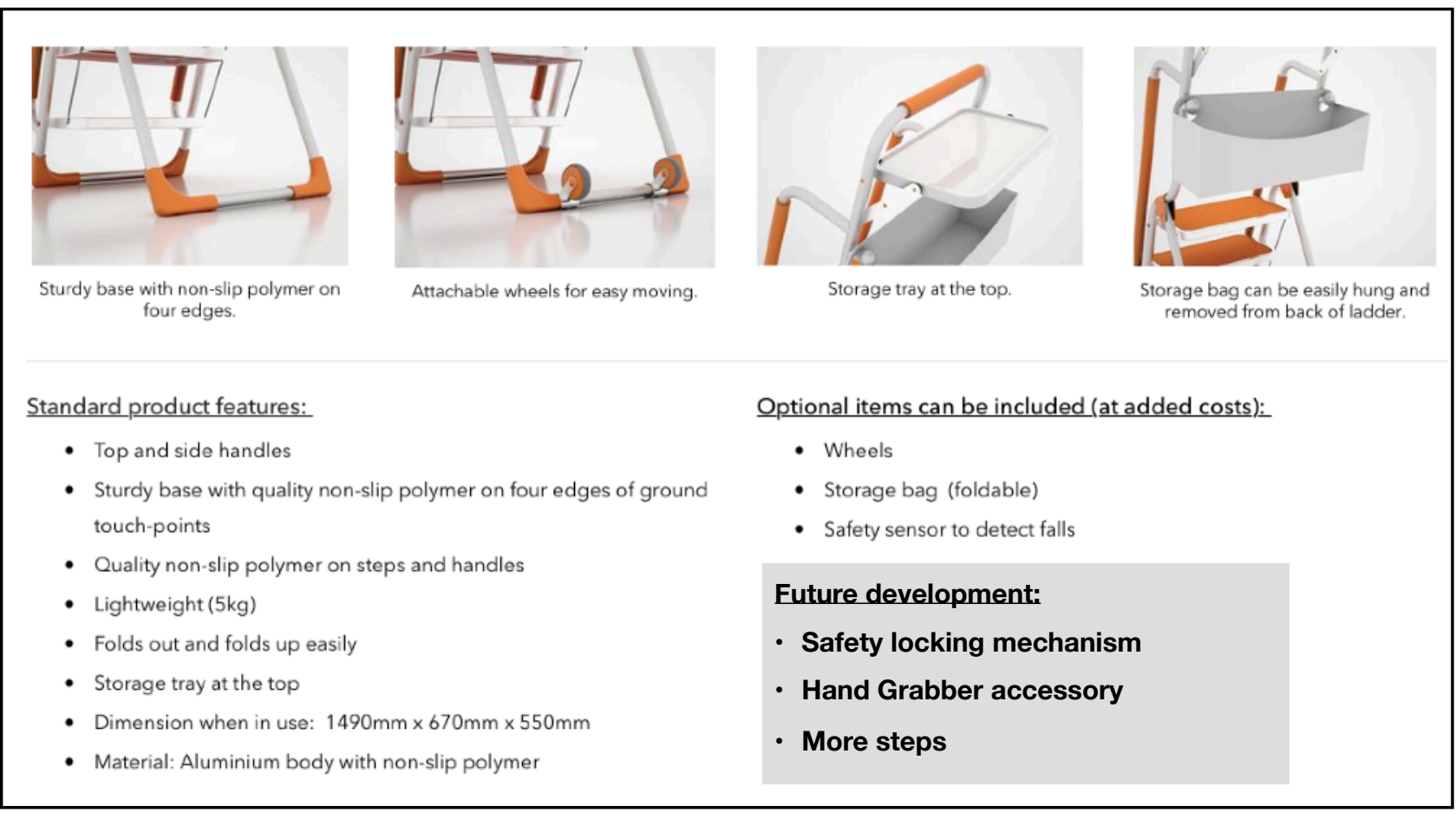




\section{Current product features validated through consumer research}

Simple Steps have been developed as part of this research based on consultation with its target consumers (older people). As illustrated in Figure 7.1, it is a modular concept that is available as a standard step ladder, with the option to include additional features at extra costs. In developing Simple Steps, one of the most critical features is the inclusion of side and top handles, which most seniors who participated in the research interviews were very keen on. This incremental innovation to the step ladder design drastically improves the usage safety of the tool. It has the potential to enable consumers to recover lost independence, as illustrated by an example of a senior who currently reluctantly relies on external assistance for household tasks (refer to page 41).

Other step ladder features such as being foldable, lightweight yet sturdy, has wide steps and non-slip materials were also desired by older consumers. Hence, these were included and assumed in the development of Simple Steps.

Based on overall consumer sentiment gathered from research findings, the concept's most desired additional features apart from the standard version, would be wheels, followed by fall detection sensors, then storage bag (refer to page 65). Results also revealed that step ladders which meet AUS:NZ ladder standards are important to consumers (refer to page 67), thus, HOMFI should endeavour to meet those product requirements.

\section{Development of product features for the future}

As the research did not conclude with a finalised prototype of Simple Steps, the development of the product could continue with more consultations with stakeholders. For example, an additional safety mechanism involving the folding out and up of the step ladder was raised by an engineer, a family member and an occupational therapist as a potential feature to consider. Based on their experiences, they mentioned that injuries from step ladders tend to result from not placing the feet at their maximum distance, and the concern that older people might find the opening up of a folded step ladder somewhat troublesome. It was suggested that the opening and closing of the step ladder be made more seamless and effortless. A locking or alert mechanism that ensures the step ladder is fully opened for maximum stability would further enhance safety of usage. The design of this locking system could also be patented, adding to the competitive advantage of Simple Steps as no current ladder device in the market offers this safety feature. 
Additionally, there were suggestions of having a step ladder that has more than the current three steps. This implies that there is potential demand for step ladders of different heights among older consumers. Having step ladders of different heights would add to the product line offering, and help to increase revenue streams. There could also be further development of the hand grabber as a possible accessory to Simple Steps (refer to page 53-54).

\subsection{Development, testing and regulations}

\section{Development}

Conversations with engineers and designers as part of this research focused on understanding the logical steps to take to bring a concept to a manufacturable state. The following lists provide an overview of a step-by-step approach to take for future development:

1. Work with designers to finalise the design concept or potentially a few concepts.

2. Next, the concept should be taken to a team of engineers or a manufacturer to validate the feasibility of the design, with focus first on the manufacturability.

3. More rounds of iteration should be expected.

4. Once a finalised prototype concept is ready, a detailed costing would be required, where the production process would include one-off products for testing, before larger production cycles are considered.

5. With a physical prototype, a series of testing would need be conducted. First, with a small group of people such as HOMFI team members. Then with a larger group, and should involve crucial stakeholders such as end consumers and their influencers (e.g family members, healthcare professionals). Again, rounds of iteration would be expected to refine and revise the product.

\section{Testing}

In New Zealand, it is not a government requirement to put a step ladder through professional testing agencies. However, the value of such tests might be worth investigating and could increase brand trustworthy and reliability, thereby strengthening customer relationships. For example, SGS, an international company with a New Zealand 
branch, specialises in inspection, verification, testing and certification of a wide range of consumer products (SGS, 2018). Working with a testing agency as such would provide assurance on product performance, safety, quality, and also ensure regulatory requirements of international markets are met. An excerpt of the testing services that relates to step ladders from the SGS website is showed in Figure 7.2.

Figure 7.2: Screenshot from SGS website

\section{REDACTED}

\section{Regulations}

It is not mandatory to build a step ladder that conforms to New Zealand ladder safety standards (Consumer NZ, n.d). However, as mentioned, adhering to safety standards 
ranked high as a key decision-making factor in the purchase of a step ladder (refer 67). Hence, HOMFI would endeavour to develop Simple Steps to AUS:NZ standards, or more stringent international standards, considering the eventual aim is to pursue a global strategy. This point further substantiates working with a professional testing agency such as SGS (as mentioned above), as this helps to accelerate market access of Simple Steps into countries beyond New Zealand.

In the interviews with engineers and designers, it was pointed out that a standard step ladder typically only falls under the regulation of the New Zealand Consumer Guarantees Act, which is applicable to any consumer products (Consumer Protection, 2018). However, the inclusion of fall detection sensors would constitute electrical components. Thus, it would need to adhere to Electrical Safety Regulations (WorkSafe New Zealand, 2017).

\subsection{Manufacturing costs}

As a finalised prototype was not produced within the timeframe of this project, accurate manufacturing costs are not available. However, taking reference from the average price point of step ladders in the current New Zealand market could provide a rough gauge on possible manufacturing costs (of a standard step ladder). This method makes assumptions about the profit margin of step ladder manufacturers, and works backwards to estimate the total product cost. For example, if a step ladder costs $\$ 150$ on the market, then assuming the supplier takes a $40 \%$ gross profit margin, the total cost of goods (which includes other costs such as labour and overheads) would be $60 \%$ of $\$ 150$, which is $\$ 90$.

Based on this simplified calculation, it would imply that manufacturing cost has to be lower than this price. *Note: This is based on a direct selling business model where the supplier sells directly to consumers and does not need to provide additional margins to an intermediary such as a retailer or distributor.

Using this method is also relevant to the concept of target costing (Gagne \& Discenza, 1995), where the market demand provides a guide for the pricing strategy of a product. In the research, it was observed that consumers tend to be price sensitive in the purchase of step ladders, hence, launching a new product at a competitive price would likely produce 
better results. However, most consumers have also indicated that they are willing to pay more for additional safety features. Thus, an assumption can be made that the target manufacturing cost could afford to be slightly higher than that of a standard step ladder which does not come with safety hand rails and/or attributes.

The main concept of target costing also places an emphasis on keeping production costs streamlined. If the production costs exceeds what is allowed based on the target costing method, then the product has to be redesigned. When that happens, certain attributes have to be compromised or more economical material has to be used. For example, a designer gave advice on using economical materials designed differently to achieve similar functional outcomes. It was pointed out that, based on the design of Simple Steps, top quality non-slip materials are typically expensive and would result in high manufacturing costs. One way to overcome it would be to innovate on the design processes to achieve similar functions at a lower cost. He cited an example of imprinting raised patterns on a more economically priced non-slip material to increase friction, thereby enhancing the functionality of a standard product. This method of budget-based innovations are similarly supported by another engineer interviewed. He indicated that a logical approach would be to list down all desired features, work with a designer to create a visual, then take it to an engineering team. From there, the engineers would be able to further advice on costings (by working with manufacturers), and suggest possible solutions to achieve the desired features at different budgets.

\subsection{Intellectual Property (IP) protection}

The discussion of protecting IP of Simple Steps was included in the interviews with engineers and designers. Protection of IP can ensure competitive advantage by securing exclusive usage of a range of expressions and creations (IPONZ, n.d). It also enables valuation and monetisation of design concepts and systems, which otherwise could be freely copied and replicated without any legal consequences (IPONZ, n.d). The ability to secure payment for IP opens up further revenue streams for the company. Table 7.1 provides an overview of the types of IP that are applicable to Simple Steps 


\begin{tabular}{|c|c|c|}
\hline IP type & $\begin{array}{l}\text { Description/Examples } \\
\text { (IPONZ, n.d) }\end{array}$ & $\begin{array}{l}\text { Where it is applicable to } \\
\text { Simple Steps/HOMFI }\end{array}$ \\
\hline Trademarks & $\begin{array}{l}\text { Protects the unique identity for a product or } \\
\text { service by protecting logo, name and brand. } \\
\text { Shapes and colours are included. Lasts } 10 \\
\text { years. }\end{array}$ & $\begin{array}{l}\text { HOMFI brand name, logo } \\
\text { and association with a } \\
\text { distinctive colour. }\end{array}$ \\
\hline Patents & $\begin{array}{l}\text { Legal protection that ensures rights to } \\
\text { exclusive production, usage or selling of } \\
\text { invention for up to } 20 \text { years in a particular } \\
\text { country or region. }\end{array}$ & $\begin{array}{l}\text { Safety features, such as } \\
\text { unique mechanisms as } \\
\text { part of the step ladder } \\
\text { design, or fall detection } \\
\text { sensor algorithm. }\end{array}$ \\
\hline Designs & $\begin{array}{l}\text { Protects original or new visual design of } \\
\text { product (relating to shape, configuration or } \\
\text { pattern). Lasts up to } 15 \text { years. }\end{array}$ & $\begin{array}{l}\text { Shape of Simple Steps or } \\
\text { textual or visual patterns } \\
\text { imprinted on the product. }\end{array}$ \\
\hline Copyrights & $\begin{array}{l}\text { Automatic protection of original works. For } \\
\text { example, website, computer programmes } \\
\text { and drawings. }\end{array}$ & $\begin{array}{l}\text { Website and marketing } \\
\text { materials. }\end{array}$ \\
\hline $\begin{array}{l}\text { Trade } \\
\text { secrets }\end{array}$ & $\begin{array}{l}\text { Confidential business information that is } \\
\text { critical to company operations such as } \\
\text { business strategies or processes. No official } \\
\text { legal protection but can be protected through } \\
\text { legally-binding contracts like Non-Disclosure } \\
\text { Agreements (NDA). }\end{array}$ & $\begin{array}{l}\text { Business processes and } \\
\text { relationships including } \\
\text { details of supplier and } \\
\text { distributor partnerships } \\
\text { should be kept } \\
\text { confidential. }\end{array}$ \\
\hline
\end{tabular}

The advice given by both engineers and designers was to focus on trademarks or trade secrets as methods to utilise IP for competitive advantage. The support for patents was less enthusiastic with the main reasons being the costly requirements of a patent application. Patents are also limited in terms of location and duration validity. In addition, the need to publicise the design concepts in a patent application could also potentially undermine the protection it aims to offer. However, patents are no doubt valuable especially in a global context, and could also be a tradable asset in raising funds in the future. The valuation of a business also typically increases when a company is in possession of patents. 
In the context of Simple Steps and HOMFI, the focus would first be on securing more economical IP protection such as trademarks and trade secrets, as suggested by the mentioned professionals. At the same time, product development could progress with the goal of creating patentable components. For example, the safety locking mechanism previously mentioned as a product feature to develop would potentially be a patent-worthy design. Additionally, the algorithm for the fall detection sensor device, if proven to be unique from existing methods, could also be patented.

\subsection{Ensuring product will work as intended}

Section 7.2 discussed engaging a professional testing agency to ensure Simple Steps works as intended, while affirming it meets consumer safety regulations. Apart from reliance on an external organisation, it is important to design and implement internal quality and safety control checks at each development and production stage of the product. For example, during the interviews with one of the engineers, it was pointed out that Simple Steps might have stability issues due to a miscalculation of the safety angle distance (i.e the distance between the front and back legs of the step ladder when it is folded out). This needs to be rectified. The experience highlights the importance of regularly checking back with manufacturing professionals and experts to ensure product safety and performance. It also suggests that having an engineer on board the team from the initial stage of development would be very beneficial, as engineering errors could be more easily spotted, thus saving time on the development process.

No physical prototypes were produced due to time constraints of this project, hence, physical testings were not conducted. Table 7.2 below illustrates how Consumer NZ conducted safety testings based on AUS:NZ standards, on a range of step ladders available in New Zealand (Consumer NZ, n.d). This could be a reference guide for HOMFI in the development of internal quality and safety control checks for Simple Steps, once a physical prototype is available. 


\section{Table 7.2: Step ladder testing procedure}

\section{Step Procedure}

1 Apply vertical loads to steps

2 Add various side forces to steps

3 Measure stability and how much the feet of the ladder "walked" as loads swayed side-to-side. (According to the AUS:NZ safety standard, the maximum "walk" allowed for portable ladders is under $79 \mathrm{~mm}$ ).

4 Place vertical lands on to treads. Check whether loads would bend stiles and treads, or shear tread-to-stile joints.

5 Conduct a final "walking" test to check whether above tests had weakened step ladder.

With the inclusion of other product features such as side and top handles, non-slip material, wheels, storage bag and fall detection sensor, a relevant set of safety and quality checks would need to be developed. For example, observation tests should be made to ensure the handles are easy to navigate while someone is on it and do not obstruct the way. There should also be durability testing of non-slip material such as wear and tear tests. The sensor device would also be required to go through stringent accuracy testings. A checklist for every product component or attribute would need to be developed with a professional engineer. 


\section{CHAPTER 8: RESOURCE REQUIREMENTS \& RETURNS}

\subsection{Skills required in HOMFI team}

The key business model concept of HOMFI lies in being cost-conscious by adopting a "lean and mean" approach to internal business operations. As the project is still in the early development phase, the team requirements would be categorised into four stages, listed in Table 8.1 below.

In the first stage, the initial team should be relatively lean with only core essential members, focusing on product development. It is expected that this core team will work with external development and manufacturing partners such as through a university, Callaghan Innovation or an Original Equipment Manufacturer (for example Ullrich) to bring the concept to its final prototype and production stage. When the product concept is finalised, the team should also grow to meet with additional work demands such as sales and marketing, where the focus will shift to generating revenue. The following table presents a brief human resource development plan:

Table 8.1: Overview of team plan

\begin{tabular}{|c|c|c|c|}
\hline 6 months & 6 months & 12 months & 12 months \\
\hline $\begin{array}{l}\text { Stage 1: } \\
\text { Research and } \\
\text { Development }\end{array}$ & $\begin{array}{l}\text { Stage 2: } \\
\text { Test and Pre- } \\
\text { launch }\end{array}$ & $\begin{array}{l}\text { Stage 3: } \\
\text { Commercial } \\
\text { Launch }\end{array}$ & $\begin{array}{l}\text { Stage 4: } \\
\text { Growth }\end{array}$ \\
\hline Designer & Designer & Designer & Designer \\
\hline Engineer & Engineer & Engineer & Engineer \\
\hline $\begin{array}{l}\text { Business } \\
\text { Development } \\
\text { Manager (Founder) }\end{array}$ & $\begin{array}{l}\text { Business } \\
\text { Development } \\
\text { Manager }\end{array}$ & $\begin{array}{l}\text { Business } \\
\text { Development } \\
\text { Manager }\end{array}$ & $\begin{array}{l}\text { Business } \\
\text { Development } \\
\text { Manager }\end{array}$ \\
\hline \multirow{2}{*}{$\begin{array}{l}\text { Part-timers: } \\
\text {-Sales } \times 2 \\
\text {-Public Relations \& } \\
\text { Marketing x } 1\end{array}$} & Marketing Manager & Marketing Manager & Marketing Manager \\
\hline & $\begin{array}{l}\text { Part-timers: } \\
\text {-Sales } \times 2 \\
\text {-Public Relations \& } \\
\text { Marketing x } 1\end{array}$ & Sales Manager & Sales Manager \\
\hline
\end{tabular}




\begin{tabular}{|c|c|c|c|}
\hline 6 months & 6 months & 12 months & 12 months \\
\hline $\begin{array}{l}\text { Stage 1: } \\
\text { Research and } \\
\text { Development }\end{array}$ & $\begin{array}{l}\text { Stage 2: } \\
\text { Test and Pre- } \\
\text { launch }\end{array}$ & $\begin{array}{l}\text { Stage 3: } \\
\text { Commercial } \\
\text { Launch }\end{array}$ & $\begin{array}{l}\text { Stage 4: } \\
\text { Growth }\end{array}$ \\
\hline & & $\begin{array}{l}\text { Operation and } \\
\text { administration } \\
\text { coordinator }\end{array}$ & $\begin{array}{l}\text { Operation and } \\
\text { administration } \\
\text { coordinator }\end{array}$ \\
\hline & & $\begin{array}{l}\text { Part-timers: } \\
\text {-Sales } \times 2 \\
\text {-Public Relations \& } \\
\text { Marketing x } 1\end{array}$ & $\begin{array}{l}\text { Sales and } \\
\text { customers service } \\
\text { team } \times 4\end{array}$ \\
\hline
\end{tabular}

HOMFI intends to outsource several business areas which do not justify full-time roles in initial stages. For example, a full-time accountant and/or finance manager is not required until the business is generating substantial revenue and has grown beyond a small company. Accounting and Financial services could be managed through Xero, which is an online accounting software that can be fully self-managed (Xero, 2018). A commercial lawyer would be another role which is necessary yet not required as a full time personnel. This area could be managed through online legal services such as Zegal, a subscriptionbased software firm that provides legal solutions at affordable prices (Zegal, 2018).

However, as the company grows, there are few key roles that would be required to sustain the business. A further description of the expected full team beyond Stage 4 is presented in Table 8.2.

Table 8.2: HOMFI Team in future

\begin{tabular}{|l|l|}
\hline Role & Description \\
\hline Biz whizz & $\begin{array}{l}\text { Business Development Manager with business knowledge and } \\
\text { experience and a big picture vision. }\end{array}$ \\
\hline Design hero & $\begin{array}{l}\text { Designer who takes care of all design related work, preferably with } \\
\text { knowledge and experience in a range of software mediums for } \\
\text { industrial, visual and digital designs. }\end{array}$
\end{tabular}




\begin{tabular}{|c|c|}
\hline Role & Description \\
\hline $\begin{array}{l}\text { Engineering } \\
\text { guru }\end{array}$ & $\begin{array}{l}\text { Engineer with mechanical, technical and technological } \\
\text { understanding of manufacturing. To ensure systems and checks } \\
\text { are in place for product development. }\end{array}$ \\
\hline Tech expert & $\begin{array}{l}\text { A technology expert particularly in software. This role would be } \\
\text { relevant for the development of sensor technology. }\end{array}$ \\
\hline Sales superstar & $\begin{array}{l}\text { Sales manager who takes on a leadership role of the rest of the } \\
\text { sales team. }\end{array}$ \\
\hline $\begin{array}{l}\text { Compassionate } \\
\text { customer } \\
\text { ambassadors }\end{array}$ & $\begin{array}{l}\text { Sales people who will front the company on the front line, but } \\
\text { should be focused on understanding customer needs and feedback } \\
\text { those perspectives back to the company to inform the next } \\
\text { innovations / product improvements. }\end{array}$ \\
\hline $\begin{array}{l}\text { Communication } \\
\text { and Marketing } \\
\text { maestro }\end{array}$ & $\begin{array}{l}\text { A skilled communications and marketing manager who can develop } \\
\text { and execute multiple marketing strategies successfully. }\end{array}$ \\
\hline $\begin{array}{l}\text { Conscientious } \\
\text { coordinator }\end{array}$ & $\begin{array}{l}\text { An administrative personnel who keeps everyone on tasks and } \\
\text { ensures that each department is aware of what is happening } \\
\text { collectively within the company. }\end{array}$ \\
\hline Money maven & $\begin{array}{l}\text { A finance manager to ensure a healthy balance sheet, a } \\
\text { sustainable business and best financial strategies to manage } \\
\text { cashflow. }\end{array}$ \\
\hline
\end{tabular}

\subsection{Development and manufacturing process of Simple Steps}

As Simple Steps is only at a visual prototype development stage, Table 8.3 offers a simplified breakdown of the development and manufacturing process, with the corresponding required equipment and potential supplier.

Table 8.3: Summary of development and manufacturing of Simple Steps 


\begin{tabular}{|c|c|c|c|}
\hline $\begin{array}{l}\text { Development stages } \\
\text { of Simple Steps }\end{array}$ & Description & $\begin{array}{l}\text { Equipment } \\
\text { required }\end{array}$ & $\begin{array}{l}\text { Potential } \\
\text { supplier of } \\
\text { equipment }\end{array}$ \\
\hline $\begin{array}{l}\text { Final visual } \\
\text { prototype }\end{array}$ & $\begin{array}{l}\text { A finalised visual prototype of } \\
\text { Simple Steps with technical } \\
\text { details. }\end{array}$ & $\begin{array}{l}3 \mathrm{D} \\
\text { rendering } \\
\text { software }\end{array}$ & $\begin{array}{l}\text { University's } \\
\text { School of } \\
\text { Design / } \\
\text { Callaghan } \\
\text { Innovation }\end{array}$ \\
\hline $\begin{array}{l}\text { Physical prototype } \\
\text { (miniature version) }\end{array}$ & $\begin{array}{l}\text { A printed-to-scale miniature } \\
\text { product prototype mainly for } \\
\text { visualisation purposes and to } \\
\text { better understand/refine how } \\
\text { components fit together. This will } \\
\text { help to highlight any potential } \\
\text { design or manufacturing } \\
\text { constraints which may be difficult } \\
\text { to detect on-screen, while } \\
\text { minimising production cost. }\end{array}$ & 3D printer & $\begin{array}{l}\text { University's } \\
\text { School of } \\
\text { Design/ } \\
\text { Callaghan } \\
\text { Innovation }\end{array}$ \\
\hline $\begin{array}{l}\text { Physical prototype } \\
\text { (actual sized } \\
\text { version) }\end{array}$ & $\begin{array}{l}\text { An actual testable product } \\
\text { prototype that is almost the final } \\
\text { product. Materials used should } \\
\text { be exactly the same type as the } \\
\text { commercial product. This product } \\
\text { would be tested by a group of } \\
\text { consumers, and should meet all } \\
\text { regulatory requirements. }\end{array}$ & $\begin{array}{l}\text { Manufacturi } \\
\text { ng facilities }\end{array}$ & $\begin{array}{l}\text { OEM (e.g } \\
\text { Ullrich) }\end{array}$ \\
\hline $\begin{array}{l}\text { Final product } \\
\text { (commercial } \\
\text { version) }\end{array}$ & $\begin{array}{l}\text { Final product that has been } \\
\text { through any required revisions } \\
\text { and is ready to be put to the } \\
\text { market for sale. }\end{array}$ & $\begin{array}{l}\text { Manufacturi } \\
\text { ng facilities }\end{array}$ & $\begin{array}{l}\text { OEM (e.g } \\
\text { Ullrich) }\end{array}$ \\
\hline
\end{tabular}

As indicated in the previous section, HOMFI intends to leverage on university resources and collaborate with existing New Zealand step ladder manufacturers such as Ullrich to access development and manufacturing equipment at minimal costs. The details of the 
partnership would need to be further worked out and negotiated at a later stage. The key takeaway would be that in establishing development and manufacturing partnerships. Through such partnerships, the product development process can be accelerated, and possibly cost of development (in terms of time, financial and labour) can be optimised.

\subsection{Funding needed}

As HOMFI has not been set up as a functioning company, the funding required would reflect the financial needs of a new business, where the focus is funding fixed costs and not variable costs. It is anticipated that major expenses would be salaries of core team members and product development costs (aimed to be minimised by utilising university and government resources). Table 8.4 provides an overview of the anticipated funding required for the first year of operation. It is expected that revenue would be generated and the business could be more or less self-funded from the 2nd year of operations.

Table 8.4: Anticipated funding needed

\begin{tabular}{|c|c|c|c|c|}
\hline $\begin{array}{l}\text { Type of } \\
\text { Cost }\end{array}$ & $\begin{array}{l}\text { Cost } \\
\text { breakdown }\end{array}$ & $\begin{array}{l}\text { One-off/Amount } \\
\text { per month (NZ\$) }\end{array}$ & $\begin{array}{l}\text { Total amount } \\
\text { for } 12 \\
\text { months } \\
\text { (NZ\$) }\end{array}$ & Reference \\
\hline \multirow[t]{3}{*}{$\begin{array}{l}\text { Company } \\
\text { operations }\end{array}$} & $\begin{array}{l}\text { Company } \\
\text { registration }\end{array}$ & One-off $\$ 132.25$ & $\$ 132.25$ & $\begin{array}{l}\text { Companies Office } \\
\text { Fees (Companies } \\
\text { Register, n.d) }\end{array}$ \\
\hline & $\begin{array}{l}\text { Rent (co- } \\
\text { office) }\end{array}$ & $\begin{array}{l}\$ 399.00 \text { per } \\
\text { month per person. } \\
\$ 1197.00 \text { for } 3 \\
\text { persons }\end{array}$ & $\$ 14364$ & $\begin{array}{l}\text { Bizdojo hotdesking } \\
\text { price plan } \\
\text { (Bizdojo, 2018) }\end{array}$ \\
\hline & $\begin{array}{l}\text { Computers } x \\
6\end{array}$ & One-off $\$ 9894.00$ & $\$ 9894.00$ & $\begin{array}{l}\text { Cost of MacBook } \\
\text { Air at } \$ 1649.00 \text { per } \\
\text { unit (Apple, 2018) }\end{array}$ \\
\hline
\end{tabular}




\begin{tabular}{|c|c|c|c|c|}
\hline $\begin{array}{l}\text { Type of } \\
\text { Cost }\end{array}$ & $\begin{array}{l}\text { Cost } \\
\text { breakdown }\end{array}$ & $\begin{array}{l}\text { One-off/Amount } \\
\text { per month (NZ\$) }\end{array}$ & $\begin{array}{l}\text { Total amount } \\
\text { for } 12 \\
\text { months } \\
\text { (NZ\$) }\end{array}$ & Reference \\
\hline & $\begin{array}{l}\text { Accounting } \\
\text { software } \\
\text { (Xero) }\end{array}$ & $\$ 50$ per month & $\$ 600$ & $\begin{array}{l}\text { Xero pricing plan } \\
\text { (Xero ,2018) }\end{array}$ \\
\hline & $\begin{array}{l}\text { Legal } \\
\text { software } \\
\text { (Zegal) }\end{array}$ & $\$ 100$ per month & $\$ 1200$ & $\begin{array}{l}\text { Zegal pricing plan } \\
\text { (Zegal, 2018) }\end{array}$ \\
\hline & $\begin{array}{l}\text { Salaries ( } 3 \\
\text { full-time staff) }\end{array}$ & $\begin{array}{l}\$ 10,000 \text { per } \\
\text { month }\end{array}$ & $\$ 120,000$ & $\begin{array}{l}\text { Based on average } \\
\text { graduate pay in } \\
\text { New Zealand } \\
\text { (\$40,000 per } \\
\text { annum) }\end{array}$ \\
\hline & $\begin{array}{l}\text { Salaries (3 } \\
\text { part-time } \\
\text { staff) }\end{array}$ & $\$ 5000$ per month & $\$ 60,000$ & $\begin{array}{l}\text { Based on } 50 \% \text { of } \\
\text { full time pay listed } \\
\text { above. }\end{array}$ \\
\hline & Website & $\$ 18$ per month & 216 & $\begin{array}{l}\text { Based on Weebly } \\
\text { Pro price plan } \\
\text { (converted from } \\
\text { USD). (Weebly, } \\
\text { 2018) }\end{array}$ \\
\hline & $\begin{array}{l}\text { Email } \\
\text { accounts }\end{array}$ & $\begin{array}{l}\$ 15 \text { per person. } \\
\$ 900 \text { for } 6 \\
\text { persons. }\end{array}$ & 10800 & $\begin{array}{l}\text { Based on Gsuite } \\
\text { price plan } \\
\text { (converted from } \\
\text { USD). (Gsuite, } \\
2018 \text { ) }\end{array}$ \\
\hline & Miscellaneous & $\begin{array}{l}\$ 100.00 \text { per } \\
\text { month }\end{array}$ & $\$ 1200$ & $\begin{array}{l}\text { Printing, Transport } \\
\text { Meals etc }\end{array}$ \\
\hline
\end{tabular}




\begin{tabular}{|c|c|c|c|c|}
\hline $\begin{array}{l}\text { Type of } \\
\text { Cost }\end{array}$ & $\begin{array}{l}\text { Cost } \\
\text { breakdown }\end{array}$ & $\begin{array}{l}\text { One-off/Amount } \\
\text { per month (NZ\$) }\end{array}$ & $\begin{array}{l}\text { Total amount } \\
\text { for } 12 \\
\text { months } \\
\text { (NZ\$) }\end{array}$ & Reference \\
\hline \multirow[t]{4}{*}{$\begin{array}{l}\text { Product } \\
\text { developme } \\
\text { nt }\end{array}$} & 3D rendering & \multirow{4}{*}{$\begin{array}{l}\text { Aimed to be } \\
\text { funded through } \\
\text { university } \\
\text { resources, } \\
\text { innovation labs } \\
\text { and government } \\
\text { grants as much } \\
\text { as possible. }\end{array}$} & & \\
\hline & 3D printing & & & \\
\hline & $\begin{array}{l}\text { Physical } \\
\text { prototype }\end{array}$ & & & \\
\hline & Final product & & & \\
\hline \multirow[t]{2}{*}{ Marketing } & $\begin{array}{l}\text { Branding } \\
\text { (website, } \\
\text { logo, } \\
\text { collaterals) }\end{array}$ & $\$ 2000$ one-off & $\$ 2000$ & $\begin{array}{l}\text { Ballpark figure } \\
\text { based on average } \\
\text { branding design } \\
\text { rates in New } \\
\text { Zealand. }\end{array}$ \\
\hline & $\begin{array}{l}\text { Marketing and } \\
\text { advertising } \\
\text { fees (e.g } \\
\text { Facebook, } \\
\text { and Google } \\
\text { Ad fees, } \\
\text { Promotional } \\
\text { material and } \\
\text { activities) }\end{array}$ & $\begin{array}{l}\$ 200.00 \text { per } \\
\text { month }\end{array}$ & $\$ 2400$ & \\
\hline $\begin{array}{l}\text { TOTAL } \\
\text { AMOUNT }\end{array}$ & & & 222806.25 & \\
\hline
\end{tabular}




\subsubsection{Proposed funding plan}

HOMFI intends to fund the estimated business costs through a range of funding sources and activities. Table 8.5 below provides an overview of HOMFl's funding plan. These are funding options that would be considered and further evaluated on an on-going basis.

Table 8.5: Proposed funding plan

\begin{tabular}{|c|c|c|c|c|}
\hline $\begin{array}{l}\text { Funding } \\
\text { source/ } \\
\text { activity }\end{array}$ & Description & Examples & To fund & Reference \\
\hline $\begin{array}{l}\text { Government } \\
\text { grants }\end{array}$ & $\begin{array}{l}\text { Typically project } \\
\text { specific funds to } \\
\text { assist in the } \\
\text { development } \\
\text { phase of a } \\
\text { company. }\end{array}$ & $\begin{array}{l}\text { Callaghan } \\
\text { Innovation's Getting } \\
\text { Started and Project } \\
\text { Grants }\end{array}$ & $\begin{array}{l}\text { Research } \\
\text { and } \\
\text { developme } \\
\text { nt costs } \\
\text { (up to } \\
40 \% \text { ). }\end{array}$ & $\begin{array}{l}\text { (Callaghan } \\
\text { Innovation, } \\
\text { n.d) }\end{array}$ \\
\hline Crowdfunding & $\begin{array}{l}\text { Raising funds } \\
\text { through public } \\
\text { appeal, usually } \\
\text { through } \\
\text { established online } \\
\text { platforms. }\end{array}$ & $\begin{array}{l}\text { PledgeMe.co.nz is a } \\
\text { New Zealand } \\
\text { crowdfunding } \\
\text { platform that offers } \\
\text { three types of fund } \\
\text { raising options: } \\
\text {-Project campaign } \\
\text { (raises funds through } \\
\text { public donation) } \\
\text {-Equity campaign } \\
\text { (raises funds through } \\
\text { giving away company } \\
\text { equity) } \\
\text {-Lend campaign } \\
\text { (borrows funds tied to } \\
\text { a fixed interest rate) }\end{array}$ & $\begin{array}{l}\text { General } \\
\text { costs }\end{array}$ & $\begin{array}{l}\text { (Pledge Me, } \\
\text { n.d) }\end{array}$ \\
\hline
\end{tabular}




\begin{tabular}{|c|c|c|c|c|}
\hline $\begin{array}{l}\text { Funding } \\
\text { source/ } \\
\text { activity }\end{array}$ & Description & Examples & To fund & Reference \\
\hline $\begin{array}{l}\text { Business } \\
\text { bank loans }\end{array}$ & $\begin{array}{l}\text { Business loans } \\
\text { are typically } \\
\text { suitable in the } \\
\text { short-term to } \\
\text { cover any } \\
\text { cashflow } \\
\text { shortfalls. }\end{array}$ & $\begin{array}{l}\text { Kiwi Bank working } \\
\text { capital loan. }\end{array}$ & $\begin{array}{l}\text { Gaps in } \\
\text { business } \\
\text { cashflow } \\
\text { and } \\
\text { inventory, } \\
\text { to support } \\
\text { operational } \\
\text { activities. }\end{array}$ & $\begin{array}{l}\text { (Kiwibank, } \\
\text { 2018) }\end{array}$ \\
\hline $\begin{array}{l}\text { Angel } \\
\text { Investors }\end{array}$ & $\begin{array}{l}\text { Investors who } \\
\text { invest at early } \\
\text { stage of a } \\
\text { business, taking } \\
\text { equity and } \\
\text { expects } 20 \text { to } 25 \% \\
\text { return on } \\
\text { investment. An } \\
\text { advantage is they } \\
\text { share expertise } \\
\text { and skills to } \\
\text { support business } \\
\text { growth. }\end{array}$ & $\begin{array}{l}\text { ICE Angels } \\
\text { Showcase Fund. }\end{array}$ & $\begin{array}{l}\text { General } \\
\text { costs }\end{array}$ & $\begin{array}{l}\text { (ICE Angels, } \\
\text { 2017) }\end{array}$ \\
\hline $\begin{array}{l}\text { Product pre- } \\
\text { sales }\end{array}$ & $\begin{array}{l}\text { Pre-selling } \\
\text { products based on } \\
\text { final prototype to } \\
\text { generate } \\
\text { advanced sales } \\
\text { revenue. }\end{array}$ & $\begin{array}{l}\text { A final physical } \\
\text { prototype of Simple } \\
\text { Steps can be taken to } \\
\text { consumers. } \\
\text { Interested parties } \\
\text { could place an } \\
\text { advanced order for } \\
\text { the product by } \\
\text { making partial } \\
\text { payment. }\end{array}$ & $\begin{array}{l}\text { Production } \\
\text { and } \\
\text { operation } \\
\text { costs. }\end{array}$ & N/A \\
\hline
\end{tabular}




\subsection{Financial forecasts}

As actual production costs of Simple Steps have not been established, this project has adopted a target price strategy approach (refer to section 7.3 ) to estimate financial forecasts. Based on consumer research (refer to Chapter 3), it would appear that Simple Steps should be able to aim for a selling price of approximately $\$ 150.00$. Based on this selling price and an assumption that production costs accounts for $60 \%$ of the price, Table 8.6 presents an estimated break-even analysis.

Table 8.6: Break-even analysis

\begin{tabular}{|c|c|c|c|}
\hline $\begin{array}{l}\text { Selling price of } \\
\text { Simple Steps } \\
\text { (standard, no } \\
\text { additional } \\
\text { features) }\end{array}$ & $\begin{array}{l}\text { Variable cost of } \\
\text { goods sold ( } 60 \% \\
\text { of selling price) }\end{array}$ & $\begin{array}{l}\text { Deduct } 10 \% \\
\text { commission (given } \\
\text { to retail } \\
\text { consignment } \\
\text { partners) }\end{array}$ & $\begin{array}{l}\text { Gross Profit per } \\
\text { unit }\end{array}$ \\
\hline 150 & 90 & 15 & 45 \\
\hline
\end{tabular}

- Total fixed costs $($ refer to Table 8.4$)=\$ 222806.25$

- Break even point $=$ Total fixed cost/gross profit per unit

$=4951.25$ units $(\$ 222806.25$ divided by 45$)$

Break-even point will occur when 4952 units of Simple Steps at $\$ 150.00$ have been sold. Based on ACC statistics (ACC, 2018), total ladder related home injury claims in 2017 among people aged 60 and above was 6045 . Achieving a sales target of 4952 units seems feasible, based on the assumption that most older adults will upgrade to a safer step ladder. 


\subsection{Timeline of key activities}

Table 8.7: Timeline of key activities

\begin{tabular}{|c|c|c|c|c|}
\hline $\begin{array}{c}\text { Stage } 1 \\
\text { (6 months) }\end{array}$ & $\begin{array}{c}\text { Stage } 2 \\
\text { (6 months) }\end{array}$ & $\begin{array}{c}\text { Stage 3a } \\
\text { (6 months) }\end{array}$ & $\begin{array}{c}\text { Stage 3b } \\
\text { (6 months) }\end{array}$ & $\begin{array}{c}\text { Stage } 4 \\
\text { (12 months) }\end{array}$ \\
\hline $\begin{array}{l}\text { Set up } \\
\text { company }\end{array}$ & $\begin{array}{l}\text { Develop and } \\
\text { test }\end{array}$ & Soft launch & Official launch & $\begin{array}{l}\text { Expand and } \\
\text { grow }\end{array}$ \\
\hline $\begin{array}{l}\text { Register and } \\
\text { set up } \\
\text { company }\end{array}$ & $\begin{array}{l}\text { Prototype } \\
\text { finalised }\end{array}$ & Consumer trial & Starts sales & $\begin{array}{l}\text { Review } \\
\text { operations and } \\
\text { team } \\
\text { performance }\end{array}$ \\
\hline $\begin{array}{l}\text { Recruit } \\
\text { designer/ } \\
\text { engineer }\end{array}$ & Internal testing & $\begin{array}{l}\text { Review trial } \\
\text { feedback }\end{array}$ & $\begin{array}{l}\text { Gather } \\
\text { testimonies } \\
\text { from customers }\end{array}$ & $\begin{array}{l}\text { Listen to } \\
\text { feedback and } \\
\text { change } \\
\text { strategies if } \\
\text { needed }\end{array}$ \\
\hline $\begin{array}{l}\text { Legal contracts } \\
\text { signed }\end{array}$ & $\begin{array}{l}\text { First round of } \\
\text { external testing }\end{array}$ & $\begin{array}{l}\text { Media and } \\
\text { publicity launch }\end{array}$ & $\begin{array}{l}\text { Full sales and } \\
\text { marketing } \\
\text { campaign }\end{array}$ & $\begin{array}{l}\text { Make decisions } \\
\text { on new product } \\
\text { development }\end{array}$ \\
\hline $\begin{array}{l}\text { Establish } \\
\text { supplier } \\
\text { partnerships }\end{array}$ & Refine product & $\begin{array}{l}\text { Fund raising (if } \\
\text { required) }\end{array}$ & $\begin{array}{l}\text { Observe sales } \\
\text { trends }\end{array}$ & $\begin{array}{l}\text { *Iterative } \\
\text { innovation } \\
\text { process of } \\
\text { consult, } \\
\text { collaborate, }\end{array}$ \\
\hline $\begin{array}{l}\text { Develop } \\
\text { branding, } \\
\text { website }\end{array}$ & $\begin{array}{l}\text { Ensure } \\
\text { regulatory } \\
\text { requirements } \\
\text { are met }\end{array}$ & $\begin{array}{l}\text { Launch sales } \\
\text { strategy (online } \\
\text { marketing and } \\
\text { community } \\
\text { education) }\end{array}$ & $\begin{array}{l}\text { Identify more } \\
\text { opportunities } \\
\text { such as high } \\
\text { performing } \\
\text { market } \\
\text { segments or } \\
\text { potential new } \\
\text { segments }\end{array}$ & co-create \\
\hline
\end{tabular}




\begin{tabular}{|c|c|c|c|c|}
\hline $\begin{array}{c}\text { Stage } 1 \\
\text { (6 months) }\end{array}$ & $\begin{array}{c}\text { Stage } 2 \\
\text { (6 months) }\end{array}$ & $\begin{array}{l}\text { Stage 3a } \\
\text { (6 months) }\end{array}$ & $\begin{array}{l}\text { Stage 3b } \\
\text { (6 months) }\end{array}$ & $\begin{array}{c}\text { Stage } 4 \\
\text { (12 months) }\end{array}$ \\
\hline $\begin{array}{l}\text { Set up } \\
\text { company }\end{array}$ & $\begin{array}{l}\text { Develop and } \\
\text { test }\end{array}$ & Soft launch & Official launch & $\begin{array}{l}\text { Expand and } \\
\text { grow }\end{array}$ \\
\hline \multirow[t]{4}{*}{$\begin{array}{l}\text { Apply for } \\
\text { grants, loans, } \\
\text { crowdfund }\end{array}$} & Pre-sales & $\begin{array}{l}\text { Listen to } \\
\text { feedback and } \\
\text { change } \\
\text { strategies if } \\
\text { needed }\end{array}$ & $\begin{array}{l}\text { Listen to } \\
\text { feedback and } \\
\text { change } \\
\text { strategies if } \\
\text { needed }\end{array}$ & \\
\hline & Invite investors & & & \\
\hline & $\begin{array}{l}\text { Seek retail and } \\
\text { community } \\
\text { partners }\end{array}$ & & & \\
\hline & $\begin{array}{l}\text { Recruit team } \\
\text { members }\end{array}$ & & & \\
\hline
\end{tabular}




\section{CHAPTER 9: CONCLUSION}

\subsection{Recap of research}

This research explored older people's needs and motivations in relation to accessing high places at home. The findings revealed this need is important because of a desire for independence and "successful ageing".

Through the process, a relevant innovation (i.e Simple Steps - a modular concept of a safer step ladder) was developed and further validated with a range of stakeholders including end-consumers (older adults), influencers (family members, healthcare professionals), enablers (resource and technology suppliers) and an intermediary (retirement village).

A collaborative business model to market Simple Steps through brand concept "HOMFI (Home Objects Made for Independence)" was developed based on stakeholder sentiments and a further analysis of current commercial climate and evolving trends. Relevant market, product and resource strategies were put forth to strengthen the case for commercialisation.

\subsection{Key outtakes and Implications}

\section{Consumer motivations and desires}

One of the key outtakes of the research is that there is a gap in the market for brands and innovations catered to older consumers. It appears this is due to a lack of understanding of older consumers' needs and desires. Seniors are mostly focused on independence even if it means taking risks, while the others are more concerned about safety and minimising risks at the expense of independence. A major implication for product innovators and businesses is the necessity to delve into the underlying motivations of older people's actions. Awareness must also be raised to bridge the gap between seniors and other stakeholders.

Specific to the project topic of accessing high places at home, another major outtake is that successful ageing for older adults, is about independence, continuity of life patterns, and a gradual progression through the stages of Baltes' theory of Selection, Optimisation 
and Compensation. There is desire for assistive technology that takes on a familiar form but also willingness to accept radical innovation (i.e fall detection sensors), as long as it fits their needs.

\section{Design implications}

This implies that, to ensure acceptance of technology, innovations should fit the needs of the user. Assistive technology for older consumers must be developed with the aim of respecting and recognising older people as independent individuals. Innovations that fail to acknowledge this will not achieve consumer acceptance and commercial success. Assistive tools should be designed with incremental changes in form, but can have radical technology as long as it is discreet, unobtrusive and easy-to-use. The desire for continuing of life patterns suggest a design philosophy of creation innovations for "task facilitation" instead of "task elimination".

\section{Different segments of "older consumer"}

The research has also highlighted the need for innovators to have better understanding of the transitions of ageing. It should not assumed a 60 year old would have the same needs as a 90 year old. Older consumers should not be generalised into one segment. Just as there are market segments for younger people (for example, children, teenagers, young adults and adults) all within a span of 30 years, it is necessary to recognise different categories of "older consumers'.

Relating back to design implications, this suggests a paradigm of designing for adaptability (i.e modular concepts) where products can "age successfully" with consumers. This achieves the goal of ensuring tool familiarity and enabling safety for as long as possible. The development of Simple Steps as a modular system reflects this ideology.

\section{A more positive image of what older means}

Findings from this research also revealed that product acceptance can be affected by how it is being promoted and marketed. Most older consumers indicated a dislike of current messages attached to senior-related products. It appears there is an over-emphasis of older people being seen as "needing help" because they are no longer able to do certain things, when most older adults are proud of (and want to be reminded) of their independence. 
Thus, it is important to ensure that marketing messages of products catered to older consumers should highlight the positivity of ageing and possibilities (instead of limitations) of later life. Promotion and communication messages need to be empowering, instead of emphasising assistance.

\section{Opportunities beyond the home}

With an ageing population, there will be more older people in the workforce. There is a strong case for businesses to look ahead and ensure that the work environment remains safe for older workers. Looking beyond the home environment, Simple Steps could be offered to businesses that require tools for access to high spaces such as supermarkets, libraries, retail shops, hotels and so forth.

\subsection{Future steps}

\section{Developing a business ecosystem}

The results of this research have shown that a conducive environment in New Zealand exists for the development of a business ecosystem catered to older consumers. Such an ecosystem will aid innovation and commercialisation. Relevant organisations and individuals already exist, such as government and voluntary organisations advocating for the interests of older people, design, technology and manufacturing suppliers and so forth. What is lacking is an integrated community or platform that connects and links these parties together for better collaborations and partnerships.

The next steps to take for this project would be to set up a system and/or structure to connect relevant stakeholders to facilitate a business community catered to older consumers. Through this, more ideas for innovation could be collected and a stronger voice representing the interests of older people would be heard, both of which, as highlighted in this research, are essential to ensuring commercial success.

This research was conducted as a first step of a project with international potential, where a similar investigation could be adapted and replicated in another country with an ageing population. 
To conclude, this research highlights the importance of better understanding and respecting the needs and desires of older consumers in order to unlock commercialisation opportunities in an ageing population. 


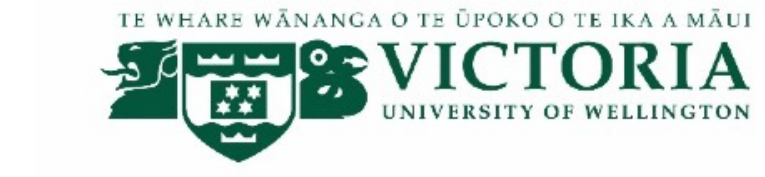

\section{Potential innovation to help seniors with safer access to high places at home.}

\section{INFORMATION SHEET FOR PARTICIPANTS}

Thank you for your interest in this project. Please read this information before deciding whether or not to take part. If you decide to participate, thank you. If you decide not to take part, thank you for considering my request.

\section{Who am I?}

My name is Geline Lim and I am a Masters student in Innovation and Commercialisation at Victoria University of Wellington. This research project is work towards my Masters thesis.

What is the aim of the project?

This project aims to:

1. To explore

a) the needs of safe access to high places at home among seniors and the potential challenges they face

b) the importance of safe access to high places at home among seniors and how it contributes to independence and wellbeing.

In order to,

2. Identify innovation and commercialisation opportunities of a suitable solution. Ideas put forward by research participants may influence the development of commercially viable products beyond university research.

This research has been approved by the Victoria University of Wellington Human Ethics Committee. [Approval number: 24925] 


\section{How can you help?}

If you agree to take part I will interview you at an agreed location. I will ask you questions relating to your opinions about safe access to high places at home (among seniors). The interview will take maximum 1 hour (but most likely less than that). I will audio record the interview with your permission and write it up later. You can choose to not answer any question or stop the interview at any time, without giving a reason. You can withdraw from the study by contacting me at any time before 1 st of April 2018. If you withdraw, the information you provided will be destroyed or returned to you.

\section{Photography as part of the interview}

If the interview takes place in your home, I may seek your permission to take photographs of the current tool(s) you are using to access high places at home. The photograph will not include any faces, and will not be attributed to any names and/or an address. You have the right to consent or reject any photography. Your approval or rejection of photography will not affect the interview. If you consent to photography, you will be presented with a separate "Consent to include photos in thesis" form to sign.

\section{What will happen to the information you give?}

This research is confidential ${ }^{*}$. This means that the researcher named below will be aware of your identity but the research data will be combined and your identity will not be revealed in any reports, presentations, or public documentation. You will not be named in the final report but it is possible that your organisation will be identifiable. In this case I will seek approval for the sections relating to your organisation.

Only my supervisors and I will read the notes or transcript of the interview. The interview transcripts, summaries and any recordings will be kept securely and destroyed a year after the research ends.

\section{What will the project produce?}

The information from my research will be used in my Masters degree report. It is possible that information from this research will be published in academic or professional journals, and/or be disseminated at academic or professional conferences.

\footnotetext{
* Confidentiality will be preserved except where you disclose something that causes me to be concerned about a risk of harm to yourself and/or others.
} 


\section{If you accept this invitation, what are your rights as a research participant?}

You do not have to accept this invitation if you don't want to. If you do decide to participate, you have the right to:

- $\quad$ choose not to answer any question;

- $\quad$ withdraw from the study before 1 st April 2018;

- $\quad$ ask any questions about the study at any time;

- $\quad$ receive a summary of the results of this research by emailing the researcher to request a copy.

If you have any questions or problems, who can you contact?

If you have any questions, either now or in the future, please feel free to contact:

\section{Student:}

Name: Yu Han Geline LIM

University email address:

limyuha@myvuw.ac.nz

\section{Supervisor:}

Name: Judith Davey

Role: Senior Research Associate

School: School of Government

Email: Judith.davey@vuw.ac.nz

Human Ethics Committee information

If you have any concerns about the ethical conduct of the research you may contact the Victoria University HEC Convenor: Associate Professor Susan Corbett. Email susan.corbett@vuw.ac.nz or telephone +64-4-463 5480. 


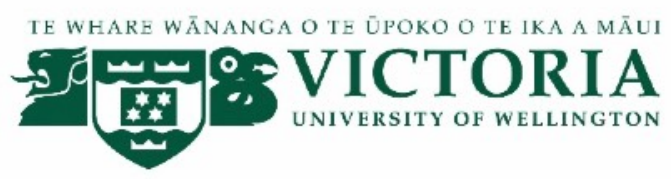

\section{CONSENT TO INTERVIEW}

This consent form will be held until 1st May 2018.

\section{Researcher: Yu Han Geline Lim, School of Chemical and Physical Sciences, Victoria University of Wellington.}

- I have read the Information Sheet and the project has been explained to me. My questions have been answered to my satisfaction. I understand that I can ask further questions at any time.

- I agree to take part in an interview, with my answers recorded in written form by the researcher.

- I agree to take part in an audio recorded interview.

\section{I understand that:}

- I may withdraw from this study at any point before 1 st April 2018, and any information that I have provided will be returned to me or destroyed.

- The information I have provided will be destroyed immediately after the research ends on 1st May 2018.

- Any information I provide will be kept confidential to the researcher and the supervisor

- I understand that the results will be used for a Masters degree report and it is possible that information from this research will be published in academic or professional journals, and/or be disseminated at academic or professional conferences.

- My name will not be used in reports.

- It is possible that the organisation I belong to will be Yes No identifiable. I consent to identifying myself as a member of the organisation for the sole purpose of giving context to my opinions, but not as a representation of the official opinion of the organisation. 
- I would like to receive a copy of a short summary of the

results and have added my email address below.

Signature of participant:

Name of participant:

Date:

Contact details: 


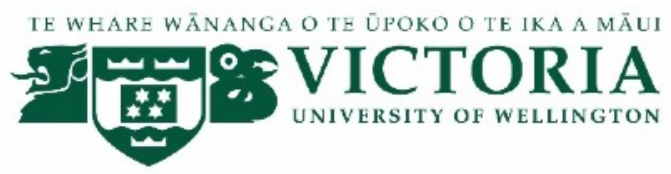

\section{Potential innovation to help seniors with safer access to high places at home.}

\section{CONSENT TO INCLUDE PHOTOS IN THESIS}

This consent form will be held until 1st May 2018.

\section{Researcher: Yu Han Geline Lim, School of Chemical and Physical Sciences, Victoria University of Wellington.}

- I agree to allow photos taken during the interview to be included in the researcher's thesis.

- I understand that the photographs taken will not include any faces, and will not be attributed to any names and/or address.

- I may withdraw from this study at any point before 1 st April 2017, and any photos taken during the interview would be destroyed.

- I understand that the photos will be used for a Masters degree report and it is possible that the photos included in this research will be published in academic or professional journals, and/or be disseminated at academic or professional conferences.

Signature of participant:

Name of participant:

Date: 


\section{Stage 1 Questions for Seniors}

Type of Dwelling (e.g Apartment/House):

Living alone/with someone: Gender: Age:

1. Within the home, are there any activities that require you to access high spaces? Name as many as possible, and frequency of it. E.g retrieving items, storage, checking fire alarm, changing lightbulb, cleaning the house etc

2. What do you use to help you access high places at home? E.g ladder, chair?

3. Do you experience any difficulties in accessing high places at home? e.g feeling unsafe, restricted by stiffness/aches/pain, difficulties in balancing etc

a. If yes, what are the difficulties you have experienced?

i. Who might help?

b. If no, do you anticipate having difficulties in the future? What would you do about it? Who might help?

4. Have you told or would you tell your family members if you experienced difficulties? (at what stage?)

a. If not, why?

5. Do you think it is dangerous accessing high places at home with the tools you used?

6. How important is it for you to be able to continue managing household tasks independently that require access to high places at home? Why?

7. Do you know of any other products/technology (apart from what you are using) that may help you safely access higher places at home? 
8. If I were to design a product for you to help you access high places at home - what would be the features you would like it to have? E.g Do you have any preference in terms of appearance, size, storage, moving it around.

9. Refer to picture (shown on page 9)- this shows some examples of different levels of technology in helping one access high spaces.

a. Could you tell me what you think of them, and which appeals most to you. *Not taking cost into consideration.

10. Would you be comfortable with health sensors (that could tell you information about your physical health - e.g balance, muscle strength)

11. Would you be comfortable with communicative technology (e.g a safety feature that can detect irregularities and notifies someone via a text message to check-in with you etc)

12. Where would you go in search for safety/mobility-related products (e.g safer ladder) to assist you at home? Name all channels: online, peers, physical stores.

13. How do feel about products that are designed and catered for seniors (including the marketing of it)?

14. Are there examples of products catered for seniors that you like/might buy?

a. Why?

15. Is there anything that you feel could make you unwilling to buy products catered to seniors?

16. How do you feel about the size of your current home (is it too big/too small?)

a. Do you have any intention to move in the future? 


\section{Questions for Family Members}

Age of senior(s): $\quad$ Age of caregiver: $\quad \mathrm{R} / \mathrm{n}$ to senior(s):

Type of dwelling(s) of senior:

1. Do you live with any senior family member?

a) If no, how often do you visit your senior family member?

b) How do you normally keep in touch with your senior family member?

2. Within the home, are there any activities that require your family member/you to access high spaces? Name as many as possible, and frequency of it. E.g retrieving items, storage, checking fire alarm, changing lightbulb, changing curtains, cleaning the house etc

3. Are there instances of having to provide assistance to help your family member with accessing high places at home?

a) How frequent, challenging is it to provide such assistance?

4. How much of a concern is it that seniors attempt to reach high places at home by themselves?

5. Do you know what your senior family member uses to help him/her access high places at home?

6. Do you know if your family member experience any difficulties in accessing high places at home? e.g feeling unsafe, restricted by stiffness/aches/pain, difficulties in balancing etc

a) If yes, what are the difficulties were experienced?

b) If no, do you anticipate your family member having difficulties in the future? What would you do about it? 
7. Do you think it is dangerous for your family member to access high places at home with the current tool(s) being used?

8. Do you know of any other products/technology (apart from what you/your family member are using) that may help you safely access higher places at home?

9. If I were to design a product for your senior family member to access high places at home - what would be the features you would like it to have?

10. Refer to picture (shown in page 19)- this shows some examples of different levels of technology in helping one access high spaces.

a) Could you tell me what you think of them, and which appeals most to you for your senior family member's use. *Not taking cost into consideration.

11. What are your thoughts on health sensors on the product (that could tell information about you or your family' members physical health - e.g balance, muscle strength)

12. What are your thoughts on communicative technology (e.g a safety feature that can detect accidents and notifies someone (e.g yourself) if an accident happened)?

13. Where would you go in search for safety/mobility-related products (e.g safer ladder) for your family member and for yourself? Name all channels: online, peers, physical stores.

14. How do feel about products that are designed and catered for seniors (including the marketing of it)

15. Are there examples of products catered for seniors that you like/might buy (for your family member...or yourself in the future)?

a) Why? 
16. Is there anything that you feel could make you unwilling to buy products catered to seniors?

17. Have you, or would you, gift household items (that enhances home safety/maintains independence) to your senior family member and why?

18.

a) (If not living with family member) - Do you know if your family member has any intention to move in the future?

b) (If living together) - Do you think there could be changes to your living arrangements in the future? 
Appendix 2.2

\section{Questions for Healthcare professionals}

Type of healthcare professional:

1. In your experiences (as a healthcare professional), have you come across injuries caused by seniors attempting to reach high places at home?

2. What are some common healthcare tools or therapy that are prescribed in order to improve or maintain physical mobility among seniors - especially relating to the movements required to access high spaces?

3. Do you know of any other product/technology that could help seniors with safe access to high places?

4. Looking at these products (shown on page 9) - which of these do you think would be the most suitable product for seniors to access high places at home? Why?

5. What are your thoughts on health sensors on products (to monitor health conditions of seniors)? And Communicative technology (to detect accidents and send notifications)?

6. Do you know of any initiatives that could support product development relating to safer access to higher places at home?

7. What are your experiences of getting seniors to accept the use of mobilityassistance tools/or to change their behaviour?

8. Do you notice if there are any senior care related products (e.g medical alarms, mobility scooters, zimmer frames) that seem to be well received by seniors?

9. Do you know of specific channels/suppliers that cater such products to seniors? 
10. How do you feel about current products/services that are designed and catered for seniors (including how they are being marketed)?

a. Are there any that you thought were really successful and well-thought through,

b. and any that you think could be improved?

Appendix 2.3

\section{Questions for Government/Voluntary organisation}

Type of organisation:

1. In your experience, have you come across common factors that contribute to seniors falling at home?

2. Is ensuring safe access to high places at home for seniors an area of concern for your organisation?

a. If yes, what are some of the actions/initiatives that are being taken?

b. If no, do you know other organisations that would be particularly interested in this area?

3. In your personal observations, do you notice any trends with regards to living arrangements among seniors? (e.g living alone, downsizing and moving into apartments, retirement villages, need for assisted care)

4. Do you know of any initiatives that could support product development relating to safer access to higher places at home? 
5. Do you notice if there are any senior care related products (e.g medical alarms, mobility scooters, zimmer frames) that seem to be well received by seniors? Or do you think they are resistant to using such products?

6. Do you know of specific channels/suppliers that cater such products to seniors?

7. Looking at these products (shown on page 9) - which of these do you think would be the most suitable product for seniors to access high places at home? Why?

8. What are your thoughts on health sensors on products (to monitor health conditions of seniors)? And Communicative technology (to detect accidents and send notifications)?

9. (For yourself) Which type of product would be prefer, and what improvements would you like it to have?

10. Do you know of any other product/technology that could help seniors with safe access to high places?

11. How do you feel about current products/services that are designed and catered for seniors (including how they are being marketed)?

12. Are there any that you thought were really successful and well-thought through, and any that you think could be improved? 


\section{Stage 2 Questions for seniors}

Age: $\quad$ Gender: Living alone/with someone:

Type of dwelling: Apartment / House

1. Do you have a step ladder at home?

2. If yes, what is it like? (e.g number of steps, with handles)

a. What do you use it for?

b. Did you buy it? If not, who bought it?

c. If so, where did you buy it?

d. How did you decide to buy it? Where did you look for information?

e. Do you have any problems with your current step ladder - any improvements you have thought of?

3. If no (but uses other tools),

a. What do you use to access high spaces at home?

i. What do you use it for?

4. If no (because there is no need to access high spaces)

a. Have you ever had a step ladder before?

b. If yes,

i. What did you use it for?

ii. How long ago was that?

iii. Why do you not have one anymore?

c. If no, why wasn't there a need?

5. How necessary is it for you to have a step ladder at home?

*Scale: "1" being unnecessary --- "10" being very necessary 
i. $\quad$ Now : (1)(2)(3)(4)(5)(6)(7)(8)(9)(10)

ii. $\quad$ Before : $(1)(2)(3)(4)(5)(6)(7)(8)(9)(10)$

iii. in the Future :(1)(2)(3)(4)(5)(6)(7)(8)(9)(10)

6. Looking at the image (shown on page 57), can you rate on a scale of 1 to 10 , the attributes of an improved step ladder (focused on safety) based on its importance to you?

* Scale: "1" not important _- "10" very important

1. Handles to steady oneself $(1)(2)(3)(4)(5)(6)(7)(8)(9)(10)$

2. Storage compartment $(1)(2)(3)(4)(5)(6)(7)(8)(9)(10)$

3. Hand Grabber (1)(2)(3)(4)(5)(6)(7)(8)(9)(10)

4. Folds flat (1)(2)(3)(4)(5)(6)(7)(8)(9)(10)

5. Wheels $(1)(2)(3)(4)(5)(6)(7)(8)(9)(10)$

6. Sturdier base (1)(2)(3)(4)(5)(6)(7)(8)(9)(10)

7. Wider steps, closer to each other $(1)(2)(3)(4)(5)(6)(7)(8)(9)(10)$

8. Non slip materials on steps and handles $(1)(2)(3)(4)(5)(6)(7)(8)(9)(10)$

9. Lightweight (1)(2)(3)(4)(5)(6)(7)(8)(9)(10)

10.Sensors to detect falls $(1)(2)(3)(4)(5)(6)(7)(8)(9)(10)$

11.Sensors to monitor balance and stability over a period of time (1)(2)(3) $(4)(5)(6)(7)(8)(9)(10)$

Other desired attributes:

7. Could you pick 2 attributes you would be willing to pay extra for?

8. If you wanted to buy a step ladder as such, how would you like to buy it? See it online, go to a store (what kind of store e.g furniture/hardware/speciality store), have a sales person come to you?

9. Looking beyond a step ladder, how do you like the idea of drop down shelves? (shown on page 9)

a. Are there any concerns about the design/concept? 
b. Would this be a better solution than a safer step ladder for your access need?

c. Is there anything that would stop you from implementing this in your home?

Appendix 2.5

\section{Question for Retirement village managers}

1. To your knowledge, do you have an idea of how many seniors are living in independent-style dwelling? (and whether there will be plans to build more?)

2. How is your retirement village's independent style dwelling different from a standard housing?

3. Does a home in this retirement village come with assistive furnishings and equipment?

4. Are there instances of having to provide extra care, manpower to assist seniors with access to high spaces? E.g lightbulbs, hanging paintings, cleaning etc

5. Have there been cases of seniors suffering from injury in their attempts to access high places at home?

6. How frequent, challenging is it to provide assistance relating to accessing high places? (e.g is there a lack of manpower/resources?)

7. How much of a concern is it that seniors attempt to reach high places by themselves?

8. Are there aspects of current equipment that enable access to high places that could be improved? 
9. Do you have any suggestions for an ideal solution?

10. What are your thoughts on this step ladder? (picture)

11. What are your thoughts on drop down shelves? (picture on page 19) - how feasible would it be to implement this concept in the RV?

12. Do you notice if there are any aged-care related products (e.g walkers, alarms, exercise equipment) that seem to be well received by seniors?

13. What are common types of mobility aids or home interior requirements requested by seniors?

14. Does the RV bring in partners/suppliers to promote products to residents?

a. If yes, what type of suppliers are they?

b. What kind of partnership is it?

c. How do you choose these partners?

15. If the improved step ladder can be manufactured, would you recommend it to your residents? 
Appendix 2.6

\section{Questions for Designers/Engineers}

1. What do think of this product sketch? Is this possible to manufacture? Can you foresee any problems with it?

2. If sensors were to be incorporated into the design, how do you think it could best be implemented?

3. What are the current innovation/production technologies available (for prototyping, manufacturing)? E.g materials, 3D printing

4. How easy is it and how long does it take to prototype a functioning product?

5. What would be the costs involved?

6. Who would be the best type of person to work with to develop it?

7. Are you aware of any regulatory requirements that need to be considered?

8. What do you think are the biggest obstacles in creating successful (i.e widely accepted) consumer products? 
Appendix 2.7

Stage 3: Online Survey

\section{Survey questions}

1. THIS STEP LADDER LOOKS APPEALINC

Strongly Agree

Agree

Neutral

Disagree

Strongly Disagree

COMMENTS IF ANY:
2. THIS STEP LADDER LOOKS SAFE TO USE.
Strongly Agree
Agree
Neutral
Disagree
Strongly Disagree
COMMENTS IF ANY

3. THIS STEP LADDER LOOKS STURDY.

Strongly Agree

Agree

Neutral

Disagree

Strongly Disagree

COMMENTS IF ANY:

4. THIS STEP LADDER LOOKS EASY TO USE. *ASSUMINC THE

WEICHT IS 5KO

Strongly Agree

Agree

Neutral

Disagree

Strongly Disagree

COMMENTS IF ANY: 
5. HOW DOES THIS STEP LADDER COMPARE WITH WHAT YOU HAVE OR HAVE SEEN AVAILABLE SO FAR?
Much Better
Somewhat Better
About the Same
Somewhat Worse
Much Worse

COMMENTS IF ANY

6. WHICH OF THE OPTIONAL FEATURES ARE YOU MOST LIKELY TO INCLUDE FOR AN ADDITIONAL COST? (YOU CAN SELECT MORE THAN ONE].

$\square$ Wheels

- Storage bag

Sensor to detect falls and automatically sends a message notification.

None of the above

IF YOU HAVE COMMENTS OR THERE ARE OTHER FEATURES NOT LISTED THAT YOU WOULD LIKE, PLEASE TYPE HERE:

7. HOW LIKELY ARE YOU TO RECOMMEND THIS STEP LADDER TO SOMEONE ELSE?

Very likely

Likely

Neutral

Onlikely

Depends

A] IF YOU SELECTED "DEPENDS', PLEASE INDICATE WHAT IT DEPENDS ON:

B) IF YOU ARE LIKELY TO RECOMMEND THIS STEP LADDER TO SOMEONE, WHO WOULD IT BE? 
8. ASSUMINC THIS STEP LADDER IS ABOUT THE SAME PRICE AS OTHER STEP LADDERS ON THE MARKET, HOW LIKELY WOULD YOU BUY IT?

Very likely

Likely

Neutral

Unlikely

Depends

I have no need for it

IF YOU SELECTED "DEPENDS", PLEASE INDICATE WHAT IT DEPENDS ON:

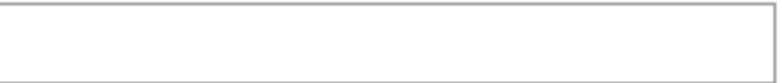

9 ASSUMINC THIS SIEP LADDER COSTS $\$ 150$ WHILE CURRENT STEP LADDERS ON THE MARKET COST $\$ 100$ (ON AVERACE), HOW LIKELY WOULD YOU BUY IT?

Very likely

Likely

Neutral

Unlikely

Depends

I have no need for it

F YOU SELECTED "DEPENDS", PLEASE INDICATE WHAT IT DEPENDS ON:

10. IF YOU WERE TO BUY THIS STEP LADDER, WHO WOULD IT BE FOR? (YOU CAN SELECT MORE THAN ONE)

$\square$ Myself

$\square$ Someone else

$\square$ I will not buy it

IF YOU SELECTED "SOMEONE ELSE" PLEASE INDICATE THE PERSON(S) E.C PARENT, SPOUSE, CHILD, FRIEND:

11. THIS STEP LADDER CAN COME WITH A SENSOR TO DETECT FALLS AND AUTOMATICALLY SENDS A MESSACE NOTIFICATION. WHAT IS THE PREFERRED WAY THAT THIS WORKS?

Sensor is embedded in the ladder and only activates when ladder is in use

Sensor is an accessory worn on the body and will detect falls in general

Do not like the idea of sensors 
12. FOR A SENSOR THAT IS WORN ON THE BODY, WHAT TYPE OF ACCESSORY DO YOU PREFER? (YOU CAN SELECT MORE THAN

$\mathrm{ONE}$

$\square$ Ring

$\square$ Wristband or bracelet

$\square$ Belt

$\square$ Watch

$\square$ Necklace

$\square$ A clip or pin attached to clothing

$\square$ Do not like idea of sensors

IF THERE ARE OPTIONS NOT LISTED HERE, PLEASE TYPE HERE:

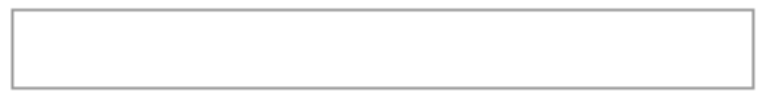

13. ANY OTHER SUCCESTIONS TO IMPROVE THIS STEP LADDER?

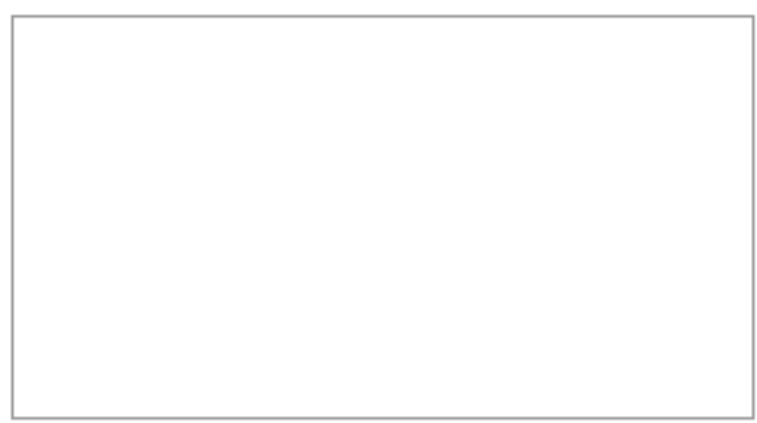

14. WHICH OF THESE WOULD BE A. DECIDING FACTOR IF YOU BOUCHT THIS LADDER? * YOU CAN SELECT MORE THAN ONE

$\square$ It adheres to the AUS/NZ ladder safety standards

$\square$ It is the most affordable option on the market

$\square$ It has good reviews from other consumers

$\square$ It was recommended by someone I know

$\square$ I was able to test the ladder in person

OTHER FACTORS PLEASE TYPE HERE:

*INDICATES REQUIRED FIELD

CODE STATED IN EMAIL *

SUBMIT 


\section{References}

2degrees. (2012). 2degrees launces first 'Senior' phone. Retrieved from https://www. 2degreesmobile.co.nz/company/news-and-media-releases

ACC. (2018). Customised Enquiry: analytics@acc.co.nz. Statistics on falls/injuries from ladder use at home among people aged 50 and older (Data from 1 January 2017 to 31 December 2017). Analytics \& Reporting.

Apple. (2018). Macbook. Retrieved from https://www.apple.com/nz

Amazon. (2018). Pearstone PSL3S 3-Step HD Photographers Ladder with Wheels.

Retrieved from

https://www.amazon.com/Pearstone-PSL3S-3-Step-Photographers-Ladder

Angwin, D., Cummings, S., \& Smith, C. (2011). The Strategy Pathfinder. (2nd ed.). West Sussex, United Kingdom: John Wiley \& Sons.

Baggozzi, R. P., \& Lee, K. (1999). Consumer Resistance To, and Acceptance Of, Innovations. Advances in Consumer Research. 26, 218-225.

Ball, M. M., Perkins, M. M., Whittington, F. J., Hollingsworth, C., King, S. V., \& Combs, B. L., (2004). Independence in assisted living. Journal of Aging Studies. 18(4), 467-483.

Bizdojo. (2018). Our Plans and Pricing. Retrieved from https://www.bizdojo.com/plans_

Beehive Government Press Release. (2016). ACC invests $\$ 30 m$ to reduce falls and fractures for older New Zealanders. Retrieved from https://www.beehive.govt.nz/release/acc-invests-30m-reduce-falls-and-fractures-oldernew-zealanders 
Birren, J. E., \& Schaie, K. W. (2006). Handbook of the psychology of aging (5th ed.). San Diego, CA: Academic Press.

Brewster, S. (2016, June 3). The Elderly May Toss Their Walkers For This Robotic Suit. Retrieved from https://www.technologyreview.com/s/601420/the-elderly-may-toss-their-walkers-for-thisrobotic-suit/

Chen, K., \& Chan, A. H. S. (2011). A review of technology acceptance by older adults. Gerontechnology. 10(1), 1-12.

https://doi.org/10.4017/gt.2011.10.01.006.00

Coleman, T., Kearns, R., \& Wiles, J. (2016) Older adults' experiences of home maintenance issues and opportunities to maintain ageing in place. Housing Studies. 31(8), 964-983.

https://doi.org/10.1080/02673037.2016.1164834

Consumer Protection. (2018). Consumer Guarantees Act. Retrieved from https://www.consumerprotection.govt.nz

Bebop Sensors. (2018). How BeBop Works. Retrieved from https://www.bebopsensors.com

Biggs, S. (2014). Adapting to an Ageing Society: The need for cultural change. Policy Quarterly. 10(3), 12-16.

Callaghan Innovation. (n.d). R\&D Grants. Retrieved from https:// www.callaghaninnovation.govt.nz

Chiptech (2018). About Chiptech. Retrieved from https://www.chiptech.co.nz 
Clarkson, J., \& Coleman, R. (2015). History of Inclusive Design in the UK. Applied Ergonomics. 46(2), 235-247.

https://doi.org/10.1016/j.apergo.2013.03.002

Coleman, T., Kearns, R. A., \& Wiles, J. (2016). Older adults' experiences of home maintenance issues and opportunities to maintain ageing in place. Housing Studies. 31(8), 964-983.

https://doi.org/10.1080/02673037.2016.1164834

Consumer NZ. (n.d). Ladders and stepladders. Retrieved from https://www.consumer.org.nz/products/ladders-and-stepladders/overview

Copelton, D. A. (2010). Output that counts: pedometers, sociability and the contested terrain of older adult fitness walking. Sociology of health \& illness. 32(2), 304-318. https://doi.org/10.1111/j.1467-9566.2009.01214.x

Davey, J. (2006). Housing. In Boston, J., \& Davey, J. A (Eds.), Implications of Population Ageing. (pp. 253-273). Wellington, New Zealand: Institute of Policy Studies.

Donellan, C. (2015). The Baltes' model of successful aging and its consideration for Aging Life Care/geriatric care management. Journal of Aging Life Care. 5(2). Retrieved from http://www.aginglifecarejournal.org/

Easterby-Smith, M., Thorpe, R., \& Jackson, P. (2008). Management research. (3rd ed.). London, United Kingdom: Sage Publications.

Easylife Group. (n.d). Genius Safety Step Ladder. Retrieved from https://www.easylifegroup.com/product/genius-safety-step-ladder

Edwards, N. I., \& Jones, D. A (1998). Ownership and use of assistive devices amongst older people in the community. Age and Ageing. 27, 463-468.

FallSafety. (2018). How it works. Retrieved from https://www.fallsafetyapp.com 
Freeman, R. E., Rusconi, G., Signori, S., \& Strudler, A. (2012). Stakeholder Theory(ies):

Ethical Ideas and Managerial Action. Journal of Business Ethics. 109(1), 1-2.

https://doi.org/10.1007/s10551-012-1374-7

Freund, A. M. (2008). Successful Aging as Management of Resources: The Role of

Selection, Optimization, and Compensation. Research in Human Development, 5(2), 94106.

https://doi.org/10.1080/15427600802034827

Freund, A. M., \& Baltes, P. B. (1998). Psychology and Ageing. 13(4), 531-43.

Frereday, J., \& Muir-Cochrane, E. (2006). Demonstrating Rigor Using Thematic Analysis: A Hybrid Approach of Inductive and Deductive Coding and Theme Development. International Journal of Qualitative Methods. 5(1), 80-92.

https://doi.org/10.1177/160940690600500107

Gabriel, Z., \& Bowling, A. (2004). Quality of life from the perspectives of older people. Ageing and Society. 24(5), 675-691.

https://doi.org/10.1017/S0144686X03001582

Gagne, M. L., \& Discenza, R. (1995). Target costing. Journal of Business \& Industrial Marketing. 10(1),16-22.

https://doi.org/10.1108/08858629510081559

Godfrey, M., Townshed, M. J., \& Denby, T. (2004). Building a good Life for older people in local communities. Joseph Rowntree Foundation.

https://www.jrf.org.uk/report/building-good-life-older-people-local-communities

Grey Power. (2018). Aims and Objectives. Retrieved from https://greypower.co.nz/about-us

Gsuite. (n.d). Use G Suite for all kinds of business. Retrieved from https://gsuite.google.co.nz/ 
Health Quality \& Safety Commission New Zealand. (2016). Reducing Harm from Falls. Retrieved from

https://www.hqsc.govt.nz/

ICE Angels. (2017). Welcome to ICE Angels. Retrieved from

https://www.iceangels.co.nz/

Ikea. (2018). Who we are. Retrieved from

http://franchisor.ikea.com/worldwide-ikea-franchisor/

Karmer, M. R \& Pfitzer, M. W. (2016). The Ecosystem of Shared Value. Harvard Business Review. Retrieved from

https://hbr.org/2016/10/the-ecosystem-of-shared-value

Kelly, E. (2015, April). Introduction: Business ecosystems come of age. Deloitte Insights. Retrieved from

https://www2.deloitte.com/insights

Kelly, A. J., Fausset, C. B., Rogers, W. \& Fisk, A. D. (2014). Responding to Home Maintenance Challenge Scenarios: The Role of Selection, Optimization, and Compensation in Aging-in-Place. Journal of Applied Gerontology, 33(8), 1018-1042. https://doi.org/10.1177/0733464812456631

Kiwibank. (2018). Business lending. Retrieved from

https://www.kiwibank.co.nz

Kotler, P. T., \& Keller, K. (2005). Marketing Management. (12ed.). New Jersey, United States: Prentice Hall.

Kroemer, K. H. E. (2006) "Extra-ordinary" Ergonomics: How to accommodate small and big persons, the disabled and elderly, expectant mothers, and children. USA: CRC Press. 
Liu, L., Stroulia, E., Nikolaidis, I., Miguel-Cruz, A., \& Rincon, A. R. (2016). Smart homes and home health monitoring technologies for older adults: A systematic review.

International Journal of Medical Informatics. 91, 44-59.

https://doi.org/10.1016/j.ijmedinf.2016.04.007

Maranville. S. (1992). Entrepreneurship in the Business Curriculum. Journal of Education for Business. 68(1), 27-31.

https://doi.org/10.1080/08832323.1992.10117582

Marsiske, M., Delius, J., Maas, I., Lindenberger, U., Scherer, H., \& Tesch-Romer, C.(1999). Sensory systems on old age. In P. B. Baltes \& K. U. Mayer (Eds.), Berlin aging study: Aging from 70 to 100. (pp. 360-383). Cambridge, UK: Cambridge University Press.

Manage at Home. (2018). 4 in 1 Perching Stool. Retrieved from https://www.manageathome.co.uk

Mason, K. J., \& Harris, L. C. (2006). Market orientation emphases: an exploration of macro, meso and micro drivers. Marketing Intelligence \& Planning. 24(6), 552-571. https://doi.org/10.1108/02634500610701654

McCreadie, C., \& Tinker, A. (2005). The acceptability of assistive technology to older people. Ageing \& Society. 25(1), 91-110.

https://doi.org/10.1017/S0144686X0400248X

Morris, A. (2017, July 4). Vertical transportation concept allows city dwellers to cycle up skyscrapers. Dezeen. Retrieved from

https://www.dezeen.com

Mugge, R., \& Dahl, D. W. (2013). Seeking the Ideal Level of Design Newness: Consumer Response to Radical and Incremental Product Design. Journal of Product Innovation Management. 30(1), 34-47.

https://doi.org/10.1111/jpim.12062 
Neven, L. (2010). 'But obviously not for me': robots, laboratories and the defiant identity of elder test users. Sociology of health \& illness. 32(2), 335-347.

https://doi.org/10.1111/j.1467-9566.2009.01218.x

New Zealand Companies Office. (2018). Incorporating a company. Retrieved from https://companies-register.companiesoffice.govt.nz

New Zealand Intellectual Property Office. (n.d). Intellectual Property Guidance. Retrieved from https://www.iponz.govt.nz

Nip-Glide. (n.d). Our product. Retrieved from https://www.nip-glide.com/usa

Ng, H. S., \& Kee, D. M. H. (2017). Entrepreneurial SMEs Surviving in the era of Globalization: Critical Success Factors. In S. Sindakis, \& P. Theodorou, (Eds.), Global Opportunities for Entrepreneurial Growth: Coopetition and Knowledge Dynamics within and across Firms. (pp.75 - 90). England, United Kingdom: Emerald Publishing Limited.

O'leary, Z. (2005). The essential guide to doing research. London, United Kingdom: Sage Publications.

Osterwalder, A., \& Pigneur, Y. (2010). Business model generation: A handbook for visionaries, game changers, and challengers. New Jersey, USA: John Wiley \& Sons.

Peek, S. T. M. (2017). Understanding technology acceptance by older adults who are ageing in place: A dynamic perspective. (Doctoral thesis, Tilburg University, The Netherlands). Retrieved from https://www.researchgate.net/profile/Sebastiaan_Peek/publication/320508305

Philips Lifelife. (2016). Automatic Fall Detection. Retrieved from https://www.lifeline.philips.com/medical-alert-systems/fall-detection

PledgeMe. (n.d). Welcome to PledgeMe. Retrieved from https://www.pledgeme.co.nz/about 
Reynolds, T. J., \& Gutman, J. (1998). Laddering theory, Method, Analysis, and Interpretation. Journal of Advertising Research. 28(1), 11-31.

Saarjiarvi, H. (2012). The mechanisms of value co-creation. Journal of Strategic Marketing, 20(5), 381-391

https://doi.org/10.1080/0965254X.2012.671339

Schifman, L., Bednall, D., O'Cass, A., Paladino, A., \& Kanuk, L. (2005). Consumer Behaviour. (3rd ed.). New South Wales, Australia: Pearson Education Australia.

Schofield, V., Davey, J. A., Keeling, S., \& Parsons, M. (2006). Ageing in Place. In Boston, J., \& Davey, J. A (Eds.), Implications of Population Ageing. (pp. 275-306). Wellington, New Zealand: Institute of Policy Studies.

Sheffield Hallam University Lab4Living (n.d). About us. Retrieved from https:// research.shu.ac.uk/lab4living/about

Sixsmith, A. (1986). Independence and home in later life. In Philipson, C., Benard, M., Strang, P. (Eds.), Depend. Interdepend. Old Age Theoretical Perspective and Policy Alternatives. (pp. 338-348). London, United Kingdom: Croom Helm

SGS. (2018). SGS in Brief. Retrieved from https://www.sgs.co.nz

SuperSeniors. (2017). The Business of Ageing. Retrieved from http://www.superseniors.msd.govt.nz/documents/the-business-of-ageing-update-2015.pdf

SuperSeniors. (n.d). About SuperSeniors. Retrieved from http://www.superseniors.msd.govt.nz

Seemann, K \& Barron, D. (2017, December). Design4Health, Melbourne. Proceedings of the Fourth International Conference on Design4Health 2017, Centre for Design Innovation, Swinburne University of Technology, Melbourne, Australia. 
Thielke, S., Harris,. M., Thompson, H., Patel, S., Demiris, G., \& Johnson, K. (2012). . Ageing International. 37(4), 470-488.

https://doi.org/10.1007/s12126-011-9121-4

Tinker, A. (2003). Assistive technology and its role in housing policies for older people.

Quality in Ageing and Older Adults. 4(2), 4-12.

https://doi.org/10.1108/14717794200300008

Walsh, I., Holton, J. A., Bailyn, L., Fernandez, W., Levina, L., \& Glaser, B. (2015). What Grounded Theory is...A Critically Reflective Conversation Among Scholars. Organisational Research Methods. 18(4), 581-599.

https://doi.org/10.1177/1094428114565028

Weebly. (n.d). Pricing. Retrieved from

https://www.weebly.com/pricing

Worksafe New Zealand. (2017). Electricity: Standards and testing. Retrieved from https://worksafe.govt.nz Vance, A. (2018, June 29). Facing up to an age old problem. Stuff. Retrieved from

Vitra \& Sheffield Hallam University Lab4Living. (2017). Inclusive bathroom design - as we age: a new publication by Vitra \& Lab4living. The C3RI Impact Blog. Retrieved from https:// blogs.shu.ac.uk/c3riimpact/inclusive-bathroom-design

Xero. (n.d). Easy-to-use accounting software to run your startup business. Retrieved from https://www.xero.com

Zegal. (n.d). From Zero to Legal. Retrieved from https://zegal.com/ 